Ana Carolina de Souza Rodrigues

\title{
A TUTELA DE URGÊNCIA ANTECIPADA EM CARÁTER ANTECEDENTE E AS CONTROVÉRSIAS ENVOLVENDO SUA ESTABILIZAÇÃO
}

Monografia

\section{INSTITUTO DE DIREITO}

Curso de Especialização em Direito Processual Civil 
PONTIFÍCIA UNIVERSIDADE CATÓLICA DO RIO DE JANEIRO

INSTITUTO DE DIREITO

Curso de Especialização em Direito Processual Civil

A tutela de urgência antecipada em caráter antecedente e as controvérsias envolvendo sua estabilização

Ana Carolina de Souza Rodrigues 


\section{Pontifícia Universidade Católica \\ DO RIO DE JANEIRO}

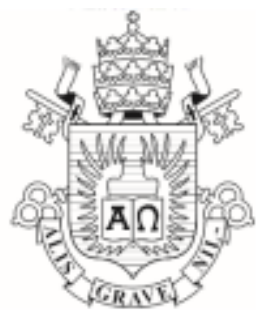

Ana Carolina de Souza Rodrigues

A tutela de urgência antecipada em caráter antecedente e as controvérsias envolvendo sua estabilização

Monografia apresentada ao Curso de Especialização em Direito Processual Civil do Instituto de Direito da PUC-Rio como requisito parcial para obtenção do título de Especialista em Direito Processual Civil.

Orientador: Prof. Bruno Garcia Redondo

Rio de Janeiro

Maio de 2018

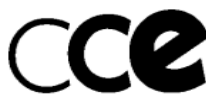

COORDENAÇÃO CENTRAL DE EXTENSÁO 


\section{AGRADECIMENTOS}

"Calma, confiança e coragem"... Palavras ditas por meu querido pai, que sempre me guiaram a alcançar os meus objetivos, superando todos os obstáculos que pudessem me afastar do caminho do sucesso.

E hoje, fazendo jus a elas, tenho o privilégio de concluir mais uma fase dessa longa jornada, podendo dedicar esse trabalho a todos aqueles que acreditam e que torcem para que meus sonhos se concretizem, vibrando em cada conquista.

Ao meu marido, meus pais, minha irmã, meu tio e meus avós. Minha querida família, que materializa o mais completo significado de amor, respeito e amizade. 


\section{RESUMO}

RODRIGUES, Ana Carolina de Souza. A tutela de urgência antecipada em caráter antecedente e as controvérsias envolvendo sua estabilização. Curso de Especialização em Direito Processual Civil, Pontifícia Universidade Católica do Rio de Janeiro, Rio de Janeiro, 2018.

O presente trabalho tem por objetivo abordar os principais aspectos envolvendo o instituto da tutela provisória de urgência satisfativa (antecipada) requerida em caráter antecedente, notadamente no que concerne as questões controvertidas relacionadas a sua estabilização, uma inovação legislativa introduzida no ordenamento jurídico brasileiro através do Código de Processo Civil de 2015. De início, será realizada uma retrospectiva sobre a origem das primeiras manifestações de tutela provisória no Brasil, até sua efetiva implementação no plano legislativo, apresentando-se as razões que motivaram o legislador brasileiro a fazer inseri-la no ordenamento processual vigente. Na sequência serão analisados os conceitos e os questionamentos envolvendo a nova classificação pelo CPC/15 ao unificar a tutela cautelar e a satisfativa (antecipada) em tutela de urgência, e ao instituir a tutela provisória da evidência. Faz-se também uma explanação das regras atinentes a tutela de urgência em caráter antecedente, esclarecendo os diversos aspectos dos ritos aplicáveis às espécies e propondo soluções para as questões que suscitam dúvidas. Por derradeiro, passa-se à análise da tutela provisória de urgência satisfativa (antecipada) requerida em caráter antecedente e das divergências ao seu respeito, concentrando especial atenção no instituto da estabilização da tutela, e nas diversas controvérsias que a envolvem, destacando-se os conflitos doutrinários relacionados à necessidade de impugnação através de recurso para obstar a estabilização; aos óbices gerais e sistemáticos identificados pelos especialistas para impedir a estabilização; as problemáticas envoltas no não aditamento da petição inicial pelo autor; as diferenças e/ou semelhanças entre estabilização e coisa julgada; as controvérsias a respeito da modificação da tutela antecipada antecedente estabilizada; e as divergências quanto a possibilidade de extensão da estabilização na tutela cautelar e na tutela da evidência.

PALAVRAS-CHAVE: PROCESSO CIVIL. TUTELA ANTECIPADA; TUTELA ANTECIPADA ANTECEDENTE; TUTELA PROVISÓRIA; ESTABILIZAÇÃO DA TUTELA. 


\section{ABSTRACT}

RODRIGUES, Ana Carolina de Souza. A tutela de urgência antecipada em caráter antecedente e as controvérsias envolvendo sua estabilização. Curso de Especialização em Direito Processual Civil, Pontifícia Universidade Católica do Rio de Janeiro, Rio de Janeiro, 2018.

The purpose of this study is to address the main aspects involved in the institution of the provisional custody of satisfactory urgency (anticipated) required onto preceding urgency, especially regarding the controversial issues related to its stabilization, a legislative innovation introduced in the Brazilian legal system through the Code of Civil Procedure of 2015. At the outset, a retrospective will be carried out on the origin of the first manifestations of provisional protection in Brazil, until its effective implementation in the legislative plane, presenting the reasons that motivated the Brazilian legislator to insert it in the current ordering procedural law. In the sequence, the concepts and concerns related to the new classification by $\mathrm{CPC} / 15$ will be analyzed thru the unification of the precautionary protection and the satisfactory (anticipated) in urgent care, and by establishing provisional custody protection of the evidence. There is also an explanation of the rules regarding urgent protection in the antecedent, clarifying the different aspects of the rites applicable to the species and proposing solutions to questions that raise doubts. Lastly, we proceed to the analysis of the provisional custody of satisfactory urgency (anticipated) required in an antecedent character and about the divergences regarding it, focusing special attention on the institute of stabilization of the custody, and in the various controversies that involve it, highlighting the doctrinal conflicts related to the need to impugnation through recourse to prevent stabilization; the general and systematic obstacles identified by the experts to prevent stabilization; the problems involved in the non-addition of the initial petition by the author; the differences and / or similarities between stabilization and res judicata; the controversies regarding the modification of the custody antecedent stabilized antecedent; and the differences regarding the possibility of extension of the stabilization in the prudential custody and in the protection of the evidence.

PALAVRAS-CHAVE: PROCESSO CIVIL. TUTELA ANTECIPADA; TUTELA ANTECIPADA ANTECEDENTE; TUTELA PROVISÓRIA; ESTABILIZAÇÃO DA TUTELA. 


\section{SUMÁRIO}

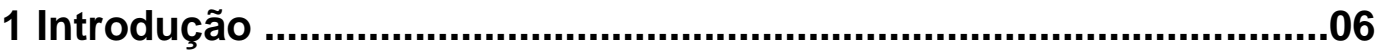

2 Breve histórico da tutela provisória no direito brasileiro....................08

2.1 O Código de Processo Civil de 1939 ................................................

2.2 Tutela provisória no Código de Processo Civil de 1973 .....................11

2.2.1 Concessão da tutela antecipada ..............................................16

2.2.2 Requisitos da tutela antecipada .............................................19

2.3 Comparativo: CPC de 1973 e CPC de 2015 .................................25

3 A tutela provisória no Código de Processo Civil de 2015 ...............30

3.1 Definição e alcance da tutela provisória ............................................30

3.2 Fundamentos da tutela provisória: urgência ou evidência ..................38

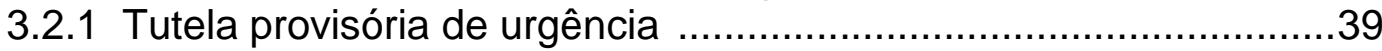

3.2.2 Tutela provisória de evidência ................................................42

3.3 Natureza da tutela provisória de urgência: cautelar ou antecipada ...47

3.4 Forma de requerimento da tutela provisória: incidental ou antecedente

4 A tutela requerida em caráter antecedente .....................................53

4.1 Conceito de tutela antecedente ...................................................53

4.2 Procedimento da tutela de urgência satisfativa (antecipada) requerida em caráter antecedente .................................................................54 4.3 Procedimento da tutela de urgência cautelar em caráter antecedente

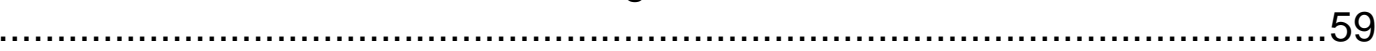

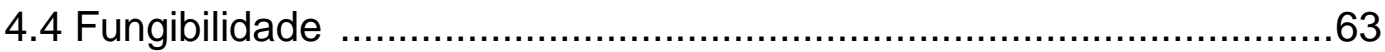

5 Controvérsias envolvendo a estabilização da tutela antecipada requerida em caráter antecedente ....................................................66

5.1 Noções gerais sobre a estabilização ............................................66

5.2 Pressupostos da estabilização ................................................72

5.2.1 Requerimento de tutela provisória satisfativa antecedente ............73

5.2.2 A existência de decisão deferindo o pedido de tutela provisória de urgência satisfativa requerida em caráter antecedente ..........................74

5.2.3 Inércia do Réu...................................................................... 76

5.2.4 Necessidade de aditamento da petição inicial pelo autor ..............80

5.3 Ação autônoma com pedido de revisão, reforma ou invalidação da tutela

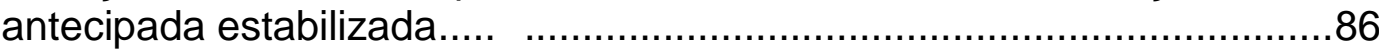

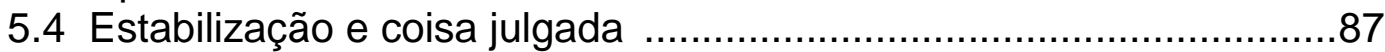

5.5 Estabilização na tutela cautelar e na tutela da evidência ..................95

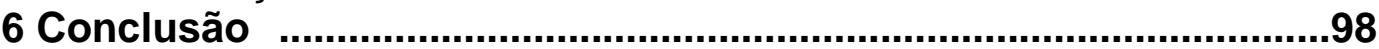

7 Referências Bibliográficas ……….................................................106 


\section{1 \\ Introdução}

A necessidade de razoabilidade na gestão do tempo constitui uma das principais tormentas na seara processual civil.

A dinâmica nas relações sociais não permite que o titular de um direito arque com o ônus da demora irrazoável do tempo necessário para a concessão de sua pretensão, pois um processo demasiadamente lento pode colocar em risco a efetividade da jurisdição, notadamente nas situações de urgência.

A rigor, o código de processo civil brasileiro sempre foi conhecido por sua morosidade, razão pela qual inseriu em seu sistema, um instituto que abrandaria os efeitos prejudiciais do tempo, assegurando a efetividade da tutela jurisdicional: a tutela provisória.

Assim, a demora na entrega jurisdicional era amenizada pelos provimentos urgentes, sendo que em 1939, quando da edição do Código de Processo Civil, podese afirmar que houve a primeira previsão de concessão de tutelas provisórias no Brasil, precipuamente no que tange as tutelas cautelares.

Decerto, essa previsão se manteve no Código de Processo Civil de 1973. No entanto foi o artigo 273, em conjunto com o artigo 461, após a reforma introduzida pela Lei no 8.952/1994, que generalizaram as hipóteses de antecipação de tutela no Código de 1973, ensejando uma verdadeira revolução no sistema processual e permitindo que no início da lide fossem antecipados os efeitos da sentença de mérito, aplicável a todo e qualquer processo.

Não obstante isso, não se pode deixar de olvidar que com o advento da Constituição da República Federativa do Brasil de 1988, diversas garantias foram inseridas em favor do cidadão, dentre elas a prevista no inciso XXXV, do seu artigo $5^{\circ}$, segundo o qual "a lei não excluirá da apreciação do Poder Judiciário lesão ou ameaça a direito".

Trata-se do princípio da inafastabilidade da jurisdição, que assegura o acesso ao Poder Judiciário com vistas a obtenção de uma justa e efetiva prestação jurisdicional.

Nesse aspecto, cada vez mais conscientes de seus direitos, a população passou a exigi-los no Judiciário, ocasionando um aumento demasiado no volume de 
demandas, de modo que o Código Buzaid de 1973 demonstrou-se ineficaz às demandas atuais.

Logo, para obstar o empecilho temporal e ser garantida uma tutela segundo os princípios que vieram a ser positivados pela Carta Política de 1988, foi editada a Lei n. $^{\circ} 13.105$ de 16 de março de 2015, que possibilitou unificar em um único instituto denominado de tutela de urgência, o procedimento da tutela satisfativa (antecipada) com o da tutela cautelar, bem como instituiu a tutela da evidência, criando mecanismos para possibilitar uma maior rapidez na prestação da tutela jurisdicional.

Ademais disso, inovando em relação ao anterior sistema, o Código de Processo Civil de 2015 criou a possibilidade de requerimento das tutelas de urgência antes do requerimento da tutela final. Assim é que passou a prever 02 (dois) procedimentos preparatórios de tutela provisória de urgência: o da tutela cautelar requerida em caráter antecedente (arts. 305 a 310) e o da tutela antecipada requerida em caráter antecedente (arts. 303 e 304). Decerto, previu o legislador a extinção do processo apenas com cognição sumária, e sem o trânsito em julgado da decisão.

Por outro norte diversas questões despontam acerca dessa nova técnica processual, de modo que o presente estudo se volta para conferir sentido e alcance a tais institutos, especialmente criados para a obtenção de uma prestação jurisdicional célere, efetiva e justa.

Nesse prisma, inicialmente será realizada uma exposição histórica e conceitual das tutelas provisórias, mais precisamente do seu desenvolvimento no sistema brasileiro. Na sequência, serão analisadas as mudanças propiciadas pelo $\mathrm{CPC} / 15$ com relação ao $\mathrm{CPC} / 73$.

Outrossim, propõe-se uma análise quanto aos procedimentos antecedentes das tutelas de urgência, para, ao final, adentrar-se nas controvérsias envolvendo o instituto da tutela provisória satisfativa (antecipada) antecedente, em especial no que tange as problemáticas relacionadas a sua estabilização. 


\section{2 \\ Breve histórico da tutela provisória no direito brasileiro}

\section{1 \\ O Código de Processo Civil de 1939}

Com efeito, desde os primórdios do direito busca-se abrandar os efeitos perniciosos do tempo, com a instituição de medidas que assegurem a plena realização do devido processo legal e a efetividade da tutela jurisdicional, sobretudo em casos de urgência.

Decerto, pode-se dizer que no direito processual civil brasileiro, entre as Ordenações Manuelinas e o início do Código de Processo Civil de 1939 não havia uma previsão do processo cautelar como um terceiro gênero de processo, pois prevaleciam medidas de caráter preventivo, sem sistematização que permitisse chegar à conclusão de que existia algo além da atividade desenvolvida para acertar a relação jurídica controvertida. ${ }^{1}$

Portanto, as primeiras tutelas provisórias no direito brasileiro foram disciplinadas pelo Código de Processo Civil de 1939, que baseou sua redação no sistema processual civil português. No seu Livro V, constava a disciplina dos processos intitulados de "processos acessórios", sendo inseridas medidas preventivas de natureza cautelar (artigo 675) ${ }^{2}$, especificadas em seu artigo 676. ${ }^{3}$

\footnotetext{
${ }^{1}$ SCARPELLI, Natália Calçado. Estabilização da tutela provisória de urgência antecipada requerida em caráter antecedente. 2016. 186 f. Dissertação (Mestrado em Direito Processual Civil) - Pontifícia Universidade Católica de São Paulo (PUC-SP), São Paulo, 2016, p. 20-21.

${ }^{2}$ Segundo o art. 675, do CPC/1939: "Além dos casos em que a lei expressamente o autoriza, o juiz poderá determinar providências para acautelar o interesse das partes: I - quando do estado de fato da lide surgirem fundados receios de rixa ou violência entre os litigantes; II - quando, antes da decisão, for provável a ocorrência de atas capazes de causar lesões, de difícil e incerta reparação, no direito de uma das partes; III - quando, no processo, a uma das partes for impossível produzir prova, por não se achar na posse de determinada coisa."

${ }^{3}$ Estabelecia do art. 676, do CPC/1939: "As medidas preventivas poderão consistir: I - no arresto de bens do devedor; II - no sequestro de coisa móvel ou imóvel; III - na busca e apreensão, inclusive de mercadorias em trânsito; IV - na prestação de cauções; V - na exibição de livro, coisa ou documento (arts. 216 a 222); VI - em vistorias, arbitramentos e inquirições ad perpetuam memoriam; VII - em obras de conservação em coisa litigiosa; VIII - na prestação de alimentos provisionais, no caso em que o devedor seja suspenso ou destituído do pátrio poder, e nos de destituição de tutores ou curadores, e de desquite, nulidade ou anulação de casamento; IX - no arrolamento e descrição de bens do casal e dos próprios de cada cônjuge, para servir de base a ulterior inventário, nos casos de desquite, nulidade ou anulação de casamento; $\mathrm{X}$ - na entrega de objetos ou bens de uso pessoal da mulher e dos filhos; na separação de corpos e no depósito dos filhos, nos casos de desquite, nulidade ou anulação de casamento."
} 
Destarte, essa categoria partia da concepção de que os processos podiam ser classificados em principal e acessório, de modo que o Livro V do Código de 1939 conglomerou vários processos que, certamente, ostentavam condição de acessórios em relação a determinadas ações.

Nesse aspecto, a doutrina fazia uma subdivisão dos processos acessórios em preparatórios, preventivos e incidentes. ${ }^{4}$

O primeiro seria o que visa instruir, fundamentar a propositura da lide principal (ex. - separação de corpos); já os preventivos objetivavam evitar fraudes, assegurando a futura efetivação do direito (ex. - o seqüestro); e, por fim, o incidente estaria vinculado ao processo acessório que surge durante a demanda (ex. embargos de terceiro).

O Livro dos "processos acessórios" se iniciava com as denominadas "medidas preventivas" (Título I). O artigo 675, caput, do CPC concedia ao juiz um poder geral para determinar providências que pudessem "acautelar" o interesse das partes. Outrossim, na sequência, em seus incisos I a III, apresentava um rol de situações em que aquelas medidas poderiam ser decretadas, ou seja:

quando do estado de fato da lide surgirem fundados receios de rixa ou de violência entre os litigantes"; "quando, antes da decisão, fôr provável a ocorrência de atos capazes de causar lesões, de difícil e incerta reparação, ao direito de uma das partes"; "quando, no processo, a uma das partes fôr impossível produzir prova, por não se achar na posse de determinada coisa. ${ }^{5}$

Note-se que existia divergência doutrinária, à época, se o artigo 675 do Código de 1939 correspondia a um "Poder Geral de Cautela" para as situações que não se enquadrassem no rol disposto no art. 676. Sobre o assunto, a doutrina afirmava que:

(...) a maioria dos processualistas entendeu estar presente na norma referida um poder geral de cautela. Os tribunais, entretanto, infelizmente não se mostraram

\footnotetext{
${ }^{4}$ VIANA, Juvêncio Vasconcelos. História do processo: uma análise do código de processo civil de 1939 sob o prisma terminológico. Disponível em: <http://www.buscalegis.ufsc.br/revistas/files/anexos/9201-9200-1-PB.pdf.>. Acesso em 16 abr. 2018.

${ }^{5}$ BRASIL. Decreto-lei $n^{\circ} 1.608$, de 18 de setembro de 1939. Código de processo civil. Disponível em: <http://www.planalto.gov.br/ccivil_03/decreto-lei/19371946/Del1608.htm>. Acesso em: 10 abr. 2018.
} 
sensíveis à necessidade do uso deste poder e foram muito tímidos na concessão de medidas cautelares que refugissem do âmbito estreito do art. $676 .{ }^{6}$

Em todo o caso, é de se reconhecer que os incisos do artigo 675, do CPC/1939 acabavam por limitar a eficácia do caput, bem como passavam a ideia de sempre se referirem a pendência de outra demanda, não possibilitando, assim, antecipar a tutela cautelar.

Entrementes, não há dúvidas em se afirmar que a falta de sistematização da tutela cautelar no Código se devia a ausência de debates prévios sobre o tema, mormente se considerado que ainda não havia sido consolidada a ideia da cautelar como um direito de ação autônomo, com características e procedimentos próprios.

$\mathrm{O}$ arresto, o seqüestro, a busca e apreensão e outras medidas preventivas nominadas (ex.: - caução, exibição, arrolamento) constavam de uma relação que figurava no artigo 676. Não foi por outra razão que partindo da premissa de que o "processo acessório" de natureza preventiva, pela circunstância de ser preparatório ou incidente deve obter pronta solução, estabeleceu o artigo 685 do CPC/1939 um procedimento mais rápido, concebido pela doutrina como uma "miniatura do processo ordinário". ${ }^{7}$

Logo, tem-se que o termo "cautelar" (processo cautelar, procedimento cautelar) era estranho ao Código de Processo Civil de 1939.

Por outro lado, no ano de 1961 foi iniciado o anteprojeto de lei que veio a dar origem ao Código de Processo Civil de 1973. Esse projeto recebeu o número de identificação 810, sendo elaborado por Alfredo Buzaid, que se inspirou nas lições de Enrico Tullio Liebman no livro Manuale di diritto processuale civile. ${ }^{8}$

O Código, depois de remetido ao Congresso Nacional, foi promulgado em 1973 pela Lei 5.869 .

\footnotetext{
${ }^{6}$ MARINONI, Luiz Guilherme. Da tutela cautelar à tutela antecipatória. 2012. Disponível em: <http://www.marinoni.adv.br/home/artigos/ >. Acesso em: 08 abr. 2018.

${ }^{7}$ Nesse sentido, VIANA, Juvêncio Vasconcelos. História do processo: uma análise do código de processo civil de 1939 sob o prisma terminológico. Disponível em: <http://www.buscalegis.ufsc.br/revistas/files/anexos/9201-9200-1-PB.pdf>. Acesso em 16 abr. 2018

${ }^{8}$ Alfredo Buzaid foi o jurista responsável por liderar o projeto de reforma do Código de Processo Civil de 1939, razão pela qual o Código de 1973 também era conhecido como "Código Buzaid". Segundo Buzaid, o Código de 1973 era “(...) um monumento imperecível de glória a Liebman, representando o fruto do seu sábio magistério no plano da política legislativa.”. (BUZAID, Alfredo. A influência de Liebman no direito processual civil brasileiro. Revista de Processo. vol. 27. p. 1226. São Paulo: RT, Jul - Set/1982. p. 24).
} 


\section{2}

\section{Tutela provisória no Código de Processo Civil de 1973}

O Código de Processo Civil de 1939 (CPC/1939), desde seu surgimento, foi objeto de intensas críticas e debates na doutrina, que afirmava que o CPC/1939 não alcançou o ideal das codificações "deixando de abranger todo o processo civil e comercial brasileiro, para confiar uma parte de sua matéria à legislação esparsa." 9 .

Outrossim, como afirmado por Carolina Cristina Miotto, a disposição do artigo $1^{\circ}$ permitiu que o $\mathrm{CPC} / 1939$, logo após a promulgação, fosse alterado por várias leis, o que com o passar dos anos tornou a legislação processual civil brasileira uma "colcha de retalhos". ${ }^{10}$

Porquanto, a reforma do CPC/1939 surgiu pela necessidade de corrigir os seus defeitos, de redigir um código que se adequasse à pluralidade de culturas, crenças e ideais da sociedade brasileira e de aperfeiçoar os institutos. A tarefa foi incumbida a Alfredo Buzaid, em 1961, pelo então Ministro da Justiça, Oscar Pedroso Horta.

O Código de Processo Civil de 1973 (CPC/1973), em relação ao seu antecessor, não teve alterações significativas. As categorias fundamentais mantiveram o mesmo modelo e o processo de conhecimento não teve alterações nas suas fases.

No Código de 1973, o Livro III, “Do Processo Cautelar”, de Título Único ("Das Medidas Cautelares") foi dividido em dois capítulos. O primeiro compreendia as disposições gerais, e o segundo os procedimentos cautelares específicos.

Nas disposições gerais do primeiro capítulo, constava o "Poder Geral de Cautela" previsto no artigo 798, segundo o qual poderia o juiz determinar as medidas provisórias que julgasse adequadas, quando houvesse fundado receio de que uma parte, antes do julgamento da lide, viesse a causar ao direito da outra lesão grave e de difícil reparação.

\footnotetext{
${ }^{9}$ PACHECO, José da Silva. Evolução do processo civil brasileiro: desde as origens até o advento do novo milênio. 2. ed. Rio de Janeiro: Renovar, 1999. p. 213.

${ }^{10}$ MIOTTO, Carolina Cristina. A evolução do direito processual civil brasileiro: de 1939 a análise dos objetivos visados pelo Projeto de Lei n. 8.046 de 2010. Disponível em: <http://periodicos.unifebe.edu.br/index.php/revistaeletronicadaunifebe/article/viewFile/135/66.>. Acesso em: 16 abr. 2018.
} 
Com efeito, para Ovídio A. Baptista da Silva ${ }^{11}$, dois eram os modos de se conceber o "Poder Geral de Cautela". Um deles estaria relacionado ao conceito de medida cautelar como "polícia judiciária" ou como o grupo de poderes que o juiz exerce para disciplinar a boa marcha do processo, de modo a afastar todos os eventuais prejuízos quanto a função e utilidade final de seu resultado.

Nessa hipótese, as simples medidas cautelares, tomadas pelo magistrado no curso da demanda de conhecimento ou execução seriam mais do que ações cautelares inominadas ou atípicas. Entrementes, as 'medidas cautelares' consubstanciadas pelo artigo 798, não teriam conteúdo de ação, mas de um mero incidente processual, na medida em que, através delas, o juiz não decidiria propriamente uma demanda cautelar. Para o ilustre doutrinador, elas dariam disciplina a um incidente da lide.

Quanto ao segundo modo, se baseava na própria redação do artigo 798 do $\mathrm{CPC}$, ao prever que "além dos procedimentos cautelares específicos", o juiz poderia permitir procedimentos cautelares inespecíficos. Nesse aspecto, concluiu o professor Ovídio A. Baptista da Silva (2006, p. 110-111), que quando o legislador previu a figura das "medidas provisórias", incluiu nesse conceito, não apenas as simples medidas, sem conteúdo de ação, que poderiam se adotas pelo magistrado para acautelar o interesse das partes, no curso da relação processual satisfativa (ou até mesmo cautelar), mas, também, as ações cautelares inominadas, que teriam um indispensável procedimento cautelar.

Em todo o caso, destacavam-se entre as regras atinentes as medidas cautelares previstas no Código de Processo Civil de 1973 as que versam sobre: a possibilidade da medida cautelar ser instaurada de forma preparatória ou incidental (artigo 796) ${ }^{12}$; a possibilidade de concessão liminar da medida cautelar, em momento anterior à manifestação do réu (artigo 804) ${ }^{13}$; a determinação para que a parte autora ajuizasse a ação principal no prazo de 30 (trinta) dias a partir da efetivação da medida

\footnotetext{
11 SILVA, Ovídio A. Baptista da. Do processo cautelar. 3. ed. Rio de Janeiro: Forense, 2006. p. $110-111$

${ }^{12}$ Art. 796. O procedimento cautelar pode ser instaurado antes ou no curso do processo principal e deste é sempre dependente.

${ }^{13}$ Art. 804. É lícito ao juiz conceder liminarmente ou após justificação prévia a medida cautelar, sem ouvir o réu, quando verificar que este, sendo citado, poderá torná-la ineficaz; caso em que poderá determinar que o requerente preste caução real ou fidejussória de ressarcir os danos que o requerido possa vir a sofrer.
} 
cautelar, quando concedida em procedimento preparatório (artigo 806) ${ }^{14}$; e a possibilidade de o juiz, a qualquer tempo, revogar ou modificar a medida cautelar concedida (artigo 807). ${ }^{15}$

Ora, a vigência do Código de Processo Civil de 1973 proporcionou a ampliação das medidas cautelares que puderam ser utilizadas em situações que necessitassem de obtenção de medidas urgentes, mesmo que não dotadas de caráter assecuratório, mas sim satisfativo. Tal fato ocorreu tanto no Brasil quanto na Europa.

Nesse sentido, consoante lições de Luiz Guilherme Marinoni ${ }^{16}$ :

A necessidade de sumarização cognitiva, advinda da busca de uma tutela jurisdicional efetiva em face de situação de perigo, levou à utilização da tutela cautelar como instrumento destinado à satisfação antecipada da pretensão que só poderia ser veiculada através da "ação principal". Se tal fenômeno - denominado por Carpi, para o direito italiano, de força expansiva da tutela cautelar - foi realmente necessário, não cabe discutir nesse momento, importando, em verdade, saber se a tutela que satisfaz a pretensão no plano fático pode ser classificada como cautelar.

Decerto, era claro que na busca da efetividade o tempo sempre foi apontado como um dos maiores obstáculos da justiça, sendo inviável exigir a celeridade do Poder Judiciário em conformidade com o que estabelece o artigo $5^{\circ}$, LXXVIII, da Carta Magna, sobretudo diante da carência de servidores que dariam os impulsos necessários ao regular trâmite dos autos, bem como o considerável número de demandas e a lentidão dos procedimentos processuais.

Destarte, a lentidão processual muitas vezes impedia o demandante de alcançar o direito postulado, razão pela qual caberia a este se socorrer através de meios processuais previstos na legislação.

Com base nessas premissas, o Código de Processo Civil de 1973 passou por diversas e significativas reformas, que certamente atingiram sua essência, alterando seus dispositivos e, notadamente, refletindo em sua estrutura e interpretação.

\footnotetext{
${ }^{14}$ Art. 806. Cabe à parte propor a ação, no prazo de 30 (trinta) dias, contados da data da efetivação da medida cautelar, quando esta for concedida em procedimento preparatório.

${ }^{15}$ Art. 807. As medidas cautelares conservam a sua eficácia no prazo do artigo antecedente e na pendência do processo principal; mas podem, a qualquer tempo, ser revogadas ou modificadas. Parágrafo único. Salvo decisão judicial em contrário, a medida cautelar conservará a eficácia durante o período de suspensão do processo.

${ }^{16}$ MARINONI, Luiz Guilherme. Tutela cautelar e tutela antecipatória. São Paulo: RT, 1992. p. 75-76.
} 
Nesse aspecto, em que se pese a contribuição das medidas cautelares, o sistema processual não tinha previsão de uma regra positivada para os casos de antecipação dos efeitos da tutela, o que ocasionou o uso incorreto dessas cautelares. Foi então que, seguindo esse movimento de renovação, com o advento da Reforma de 1994 o artigo 273 do Código de Processo Civil foi reformulado, vindo a estabelecer a possibilidade de antecipação dos efeitos da decisão final. ${ }^{17}$

O primitivo artigo 273 do Código de Processo Civil Brasileiro possuía a seguinte redação: "o procedimento especial e o procedimento sumaríssimo regemse pelas disposições que lhe são próprias, aplicando-se-lhes, subsidiariamente, as disposições gerais do procedimento ordinário."18

De acordo com os ensinamentos de Humberto Theodoro Júnior ${ }^{19}$ sobre a nova disposição legal introduzida, a regra normativa em questão possibilitou ao juiz conceder ao autor (ou ao réu, nas ações dúplices) um provimento liminar que, a título provisório, asseguraria a obtenção do bem jurídico objeto da relação jurídica envolvida no litígio.

Segundo esse ilustre doutrinador, a hipótese não representaria uma simples faculdade ou mero poder discricionário do juiz, mas, sobretudo, um direito subjetivo processual, de modo que uma vez observados os pressupostos previstos pela lei, autorizaria a parte interessada exigir esse direito da Justiça, como parcela da tutela jurisdicional a que o Estado se obrigou. Por isso, complementa:

Com o novo expediente, o juiz, antes de completar a instrução e o debate da causa, antecipa uma decisão de mérito, dando provisório atendimento ao pedido, no todo ou em parte. Diz-se, na espécie, que há antecipação de tutela porque o juiz se adianta para, antes do momento reservado ao normal julgamento do mérito, conceder à parte um provimento que, de ordinário, somente deveria ocorrer depois de exaurida a apreciação de toda a controvérsia e prolatada a sentença definitiva. Justifica-se a antecipação de tutela pelo princípio da necessidade, a partir da constatação de que sem ela a espera pela sentença de mérito importaria denegação de justiça, já que a efetividade da prestação jurisdicional restaria gravemente comprometida. (THEODORO JR., 1997, p. 45).

\footnotetext{
${ }^{17}$ OLIVEIRA NETO, Olavo de; MEDEIROS NETO, Elias Marques de; OLIVEIRA, Patrícia Elias Cozzolino de. Curso de direito processual civil. 1. ed. São Paulo: Verbatim, 2015, v. 1. p. 603.

${ }^{18}$ SANTOS, Ernane Fidélis dos. Manual de direito processual civil. 4. ed. São Paulo: Saraiva, 1996, v. 3. p. 313-314.

${ }^{19}$ THEODORO JR., Humberto. Tutela antecipada e tutela cautelar. Revista de Processo. vol. 742. p. 40-56. São Paulo: RT, Ago/1997. p. 45.
} 
A introdução do sobredito preceito normativo materializou o reconhecimento de que a sistemática até então vigente não respondia aos reclamos dos jurisdicionados por uma justiça célere e ao mesmo tempo eficaz, visto que em regra, no processo de conhecimento, não havia mecanismo capaz de propiciar ao autor a satisfação do direito, ainda que provisoriamente, antes da prolação da sentença.

Por vezes, a ausência deste mecanismo, dada a situação de urgência, acabava por tornar inócua a pretensão do autor, já que a resposta tardia não mais seria capaz de socorrer o seu direito.

Em contrapartida, a figura da tutela antecipada inserida pela Lei $n .^{\circ}$ 8.952/1994 foi utilizada apenas com a finalidade de remediar situações emergenciais, sujeitando-se a requisitos mais rigorosos do que aqueles presentes nas medidas cautelares.

Note-se que a antecipação da tutela acabou por restringir a atuação dos juízes, no que tange ao exercício de seu poder geral de cautela, já que foram estabelecidos requisitos específicos, quais sejam: a proibição de sua concessão quando existisse o risco de irreversibilidade ${ }^{20}$; e a determinação de que a execução da tutela antecipada se daria nos moldes da execução provisória ${ }^{21}$.

Certo é que foi o artigo 273, em conjunto com o artigo 461, após a reforma introduzida pela Lei no 8.952/1994, que generalizaram as hipóteses de antecipação de tutela no Código de 1973, ensejando uma verdadeira revolução no sistema processual e permitindo que no início da lide fossem antecipados os efeitos da sentença de mérito.

Nessa linha de raciocínio, a antecipação dos efeitos da tutela veio resolver o dilema existente entre os males do tempo e a segurança do pronunciamento judicial, sobretudo por permitir a prestação jurisdicional célere através do deferimento de medida que pode ser efetivada dentro do próprio processo de conhecimento, antes mesmo da fase decisória do processo.

\footnotetext{
20 Art. 273. (...) $\S 2^{\circ}$ Não se concederá a antecipação da tutela quando houver perigo de irreversibilidade do provimento antecipado.

${ }^{21}$ Art. 273. (...) $\S 3^{\circ}$ A execução da tutela antecipada observará, no que couber, o disposto nos incisos II e III do art. 588 .
} 


\subsection{1 \\ Concessão da tutela antecipada}

Com o advento do artigo 273 do Código de Processo Civil de 1973, alguns questionamentos foram suscitados pela doutrina, notadamente no que se refere a possibilidade de conceder a tutela antecipada inaudita altera parte; ao momento processual em que cabível seu deferimento; ou, ainda, de concedê-la sem a formulação de requerimento deduzido pela parte interessada (concessão de ofício).

No tocante a possibilidade de concessão da tutela antecipada sem a prévia participação do réu, a divergência se instaurou em razão da redação do artigo 273, II, do Código de Processo Civil de 1973, segundo o qual:

Art. 273. O juiz poderá, a requerimento da parte, antecipar, total ou parcialmente, os efeitos da tutela pretendida no pedido inicial, desde que, existindo prova inequívoca, se convença da verossimilhança da alegação e:

(...)

II - fique caracterizado o abuso de direito de defesa ou o manifesto propósito protelatório do réu.

Como se vê, o referido inciso previa a participação do réu, mediante a prática de atos protelatórios ou que restasse caracterizado o abuso do direito de defesa. Todavia, a questão foi amplamente debatida pela doutrina e jurisprudência, de modo a prevalecer o entendimento de que, mesmo sem a participação do réu, a liminar poderia ser concedida, desde que fosse levada em consideração a conduta extraprocessual comprovada antes mesmo da propositura da ação (OLIVEIRA NETO; MEDEIROS NETO; OLIVEIRA, 2015. p. 607).

Outrossim, quanto ao momento processual em que cabível a concessão da tutela antecipada, 03 (três) correntes doutrinárias buscaram elucidar a indagação.

A primeira corrente se firmou no sentido de que a tutela antecipada poderia ser concedida até antes da prolação de sentença. Quanto à segunda, defendia sua concessão até mesmo na sentença. E, por fim, para a terceira, a antecipação poderia ser concedida após a prolação da sentença (OLIVEIRA NETO; MEDEIROS NETO; OLIVEIRA, 2015. p. 607).

Na prática forense, o que se percebia era a adoção do entendimento de que a tutela antecipada somente poderia ser concedida até a prolação da sentença, o que não afastava a possibilidade de deferi-la, inclusive no mesmo ato em que proferida 
essa decisão. Não obstante, havia resistência quanto a sua concessão após esse momento.

A esse respeito, Olavo de Oliveira Neto, Elias Marques de Medeiros Neto e Patrícia Elias Cozzolino de Oliveira se manifestaram no seguinte sentido:

(...) a antecipação da tutela após o momento da sentença, segundo pensávamos, não poderia ser reconhecida como sendo correta, na medida em que estar-se-ia subtraindo uma competência que, em tese, seria do relator do recurso distribuído, este sim competente para cassar o efeito suspensivo da apelação mediante antecipação da tutela recursal. Também não entendíamos como correto adotar a segunda posição, já que a antecipação da tutela juntamente com a sentença e, no corpo desta, viria a dar causa ao desrespeito ao princípio da unicidade dos recursos, segundo o qual para cada tipo de decisão existe apenas uma espécie de recurso cabível. Isso porque, antecipada a tutela na sentença, caberia apelação daquilo que dizia respeito ao julgamento do feito, enquanto caberia, ao mesmo tempo, recurso de agravo para a parte que dizia respeito a antecipação da tutela. Era correto afirmar, portanto, que a antecipação de tutela apenas poderia ser concedida até o momento em que a sentença fosse prolatada, podendo o juiz fazê-lo até mesmo como um dos itens da decisão que juntava a sentença aos autos, mas não após esse momento, a não ser que pelo relator do recurso interposto, o que estaria a configurar outra forma de antecipação de tutela denominada antecipação de tutela recursal. (OLIVEIRA NETO; MEDEIROS NETO; OLIVEIRA, 2015. p. 607).

A propósito do tema, quanto ao instituto da antecipação de tutela recursal, o ilustre professor Bruno Garcia Redondo ${ }^{22}$ explica que trata-se de uma nomenclatura atualmente técnica para a tutela de urgência satisfativa, que consista no deferimento, pelo relator, de uma providência pela primeira vez no curso daquela demanda, tratando-se de verdadeira aplicação do art. 273 do CPC em grau recursal.

Para ele (2012, p. 59) antes da difusão da expressão "antecipação de tutela", fruto da reforma da Lei 8.952/1994 - que alterou o art. 273 - era comum encontrar as expressões "efeito ativo" ou "efeito suspensivo ativo" para identificar essa atividade pela qual o relator nem "suspendia", nem "deixava de suspender" a decisão recorrida, mas verdadeiramente concedia a medida indeferida pelo órgão $a$ quo (vê-se que o adjetivo 'ativo' buscava indicar uma conduta positiva, de concessão de uma providência indeferida).

Superado isso, outra controvérsia envolvendo a tutela antecipada fazia referência à possibilidade de concedê-la de ofício, ou seja, sem o requerimento da parte.

${ }^{22}$ REDONDO, Bruno Garcia. Tutela de urgência ("efeito suspensivo" e "tutela antecipada") em grau recursal e deveres-poderes do relator. Revista de Processo. vol. 209. p. 55-71. São Paulo: RT, Jul/2012. p. 59. 
O debate da matéria se devia a redação do artigo 273, caput, do Código de Processo Civil de 1973, que oportunizava ao juiz, a requerimento da parte, antecipar, total ou parcialmente, os efeitos da tutela pretendida no pedido inicial, desde que, existindo prova inequívoca, se convencesse da verossimilhança da alegação. Logo, esse dispositivo previa expressamente a necessidade de formulação de requerimento da parte para a antecipação da tutela.

A questão embasou importantes debates. Um dos argumentos contrários à sua concessão de ofício se baseava na interpretação literal do artigo 273, caput, do Código de Processo Civil de 1973, que previa expressamente a necessidade de requerimento da parte.

São adeptos dessa tese Nelson Nery Junior e Rosa Maria de Andrade Nery, que assim se pronunciaram:

(...) é vedado ao juiz conceder ex officio a antecipação da tutela, como decorre do texto expresso do CPC, 273, caput. Somente diante de pedido expresso do autor é que pode o juiz conceder a medida. ${ }^{23}$

Outra não é a posição de Luiz Rodrigues Wambier, Flávio Renato Correia de Almeida e Eduardo Talamini, in verbis:

(...) ter havido pedido é pressuposto para poderem ser antecipados os efeitos da sentença. Não há antecipação dos efeitos da sentença sem provocação da parte. ${ }^{24}$

Ademais, sustentava-se que a concessão de tutela antecipatória sem o requerimento impedia o direito de regresso da parte afetada pela decisão antecipatória. Por isso, reforçando a controvérsia, a indagação extraída da obra de Olavo de Oliveira Neto, Elias Marques de Medeiros Neto e Patrícia Elias Cozzolino de Oliveira (2015, p. 608), no sentido de que nos casos de dano causado ao réu pela concessão da antecipação da tutela, sem requerimento do autor, sendo, portanto, deferida de ofício pelo juízo, a quem caberia o ônus de arcar com os prejuízos sofridos?

\footnotetext{
${ }^{23}$ NERY JR., Nelson; NERY, Rosa Maria de Andrade. Código de processo civil comentado e legislação extravagante. 11. ed. São Paulo: RT, 2010. p. 548.

${ }^{24}$ ALMEIDA, Flávio Renato Correia de; TALAMINI, Eduardo; WAMBIER, Luiz Rodrigues. Curso avançado de processo civil. 10. ed. São Paulo: RT, 2008, v. 1. p. 364.
} 
Por outro lado, existia uma corrente que defendia a possibilidade da concessão da antecipação da tutela sem a necessidade de requerimento da parte. Para os seus defensores, não haveria justificativa para que o direito do autor perecesse somente porque o mesmo não formulou o requerimento.

Em todo o caso, é obvio que no exercício desse mister caberia ao magistrado a adoção dos critérios da razoabilidade e proporcionalidade, sobretudo nos casos que envolvessem direitos socialmente relevantes.

Sobre o assunto, discorreram Olavo de Oliveira Neto, Elias Marques de Medeiros Neto e Patrícia Elias Cozzolino de Oliveira, como se extrai da citação a seguir:

Em nosso entender, todavia, deveriam ser observadas as regras da razoabilidade e da proporcionalidade, não se justificando a concessão da antecipação de tutela nas causas eminentemente patrimoniais e que veiculassem direitos individuais disponíveis; enquanto era o caso da concessão da medida quando o direito posto em juízo fosse socialmente relevante. (OLIVEIRA NETO; MEDEIROS NETO; OLIVEIRA, 2015. p. 608).

Seguindo essa linha de raciocínio, caberia ao magistrado analisar minuciosamente a hipótese concreta, sendo-lhe permitido antecipar a tutela sem requerimento expresso, portanto, de ofício, numa ação pleiteando o fornecimento de medicamento (ex. insulina), mormente diante do direito subjetivo com risco de ser lesionado, como, por exemplo, à vida ou à saúde.

\subsection{2}

\section{Requisitos da tutela antecipada}

Como se sabe, a Lei n. ${ }^{\circ}$ 8.952/94, reformulando o art. 273 do Código de Processo Civil de 1973, introduziu no sistema processual civil a tutela antecipada dos efeitos da decisão de mérito, que passou a disciplinar o instituto nos seguintes termos:

Art. 273. O juiz poderá, a requerimento da parte, antecipar, total ou parcialmente, os efeitos da tutela pretendida no pedido inicial, desde que, existindo prova inequívoca, se convença da verossimilhança da alegação e:

I - haja fundado receio de dano irreparável ou de difícil reparação; ou

II - fique caracterizado o abuso de direito de defesa ou o manifesto propósito protelatório do réu. 
$\S 1^{\circ} \mathrm{Na}$ decisão que antecipar a tutela, o juiz indicará, de modo claro e preciso, as razões do seu convencimento.

$\S 2^{\circ}$ Não se concederá a antecipação da tutela quando houver perigo de irreversibilidade do provimento antecipado.

$\S 3^{\circ}$ A execução da tutela antecipada observará, no que couber, o disposto nos incisos II e III do art. 588.

$\S 4^{\circ}$ A tutela antecipada poderá ser revogada ou modificada a qualquer tempo, em decisão fundamentada.

$\S 5^{\circ}$ Concedida ou não a antecipação da tutela, prosseguirá o processo até final julgamento. ${ }^{25}$

Destarte, com vistas a efetiva obtenção da prestação jurisdicional, a nova redação do artigo 273 do Código de Processo Civil concedeu a possibilidade do magistrado conceder ao autor (ou ao réu nas ações dúplices) um provimento liminar que lhe assegure, provisoriamente, o bem jurídico questionado na relação jurídica envolvida no litígio.

Entretanto, para que se cogite da antecipação da tutela há necessidade de observância de dois requisitos genérico e obrigatório, previstos no artigo 273, caput, do Código de Processo Civil. São eles: prova inequívoca e verossimilhança da alegação.

A prova inequívoca é aquela capaz de autorizar, no momento em que requerida a antecipação da tutela, uma sentença de mérito favorável à parte que a invoque. Em outros termos, por prova inequívoca entende-se a prova suficiente para levar ao juiz a acreditar que a parte é titular do direito material disputado. É, em verdade, um juízo provisório, bastando que no momento da análise do pedido de antecipação todos os elementos conduzam o magistrado no sentido de convencê-lo da probabilidade das alegações.

Segundo Antônio Francisco de Oliveira ${ }^{26}$, inequívoca é a prova que não admite erro, conduzindo, assim ao que é verdadeiro. Mas o autor adverte no sentido de que muito embora na análise do que seja inequívoco o aplicador do direito necessite buscar parâmetros valorativos, é irrefutável que também haverá forte dose

\footnotetext{
${ }^{25}$ BRASIL. Lei ${ }^{\circ}$ 5.869, de 11 de janeiro de 1973. Código de processo civil. Disponível em: <http://www.planalto.gov.br/ccivil_03/LEIS/L5869.htm>. Acesso em: 10 abr. 2018.

${ }^{26}$ OLIVEIRA, Antônio Francisco de. Alterações do CPC: aspectos processuais trabalhistas e civis. São Paulo: RT, 1997. p. 58.
} 
de subjetivismo, a depender do maior ou menor grau de percepção de quem analisa a prova.

Por fim, destaque-se que não se trata de prova pré-constituída, mas a que permite, por si só, em juízo provisório, definir o fato, ou seja, tê-lo por verdadeiro. ${ }^{27}$ Daí a conclusão do ilustre Ministro Teori Zavascki no sentido de que o que a lei exige não é a prova da verdade absoluta - que sempre será relativa, mesmo quando concluída a instrução -, mas uma prova robusta, que embora no âmbito de cognição sumária aproxime, em segurança medida, o juízo de probabilidade do juízo de verdade. $^{28}$

No tocante a verossimilhança das alegações, refere-se ao juízo de convencimento a ser feito em torno de todo quadro fático invocado pela parte que pretende a antecipação da tutela, não apenas com relação a existência de seu direito subjetivo material, mas, precipuamente, no que tange ao perigo de dano e sua irreparabilidade, bem como ao abuso dos atos de defesa e de procrastinação praticados pelo réu. ${ }^{29}$

De acordo com Elpídio Nunes $^{30}$, a verossimilhança tem relação com a plausibilidade do direito invocado, com o fumus boni iuris. Entretanto, esclarece o doutrinador, que na antecipação da tutela, exatamente porque se antecipam os efeitos da decisão de mérito, são exigidos mais do que a fumaça: exige-se a verossimilhança, a aparência do direito.

Ultrapassado isso é de se ressaltar a existência de outros requisitos para o deferimento do benefício, quais sejam: fundado receio de dano irreparável ou de difícil reparação (inciso I do artigo 273); ou (ii) abuso do direito de defesa ou manifesto propósito protelatório do réu (inciso II do artigo 273).

Para o professor Humberto Theodoro Júnior ${ }^{31}$, o fundado receio previsto pelo inciso I, do artigo 273, do Código de Processo Civil é o que não advém de simples temor subjetivo da parte, mas que se origina de dados concretos, seguros, objeto de

\footnotetext{
27 SANTOS, Ernane Fidélis dos. Manual de direito processual civil. 4. ed. São Paulo: Saraiva, 1993. v. 1. p. 316.

${ }^{28}$ ZAVASCKI, Teori Albino. Antecipação da tutela. 6. ed. São Paulo: saraiva, 2008. p. 76.

${ }^{29}$ THEODORO JR., Humberto. Curso de direito processual civil. 20. ed. Rio de Janeiro: Forense, 1997. v. 2. p. 612.

${ }^{30}$ NUNES, Elpídio Donizetti. Curso didático de direito processual civil. 2. ed. Belo Horizonte: Del Rey, 1999. p. 167.

${ }^{31}$ THEODORO JR., Humberto. Tutela antecipada e tutela cautelar. Revista de Processo. vol. 742. p. 40-56. São Paulo: RT, Ago/1997. p. 51.
} 
prova suficiente para autorizar o juízo de verossimilhança, ou de grande probabilidade em torno do risco de prejuízo grave.

No seu entendimento, os simples inconvenientes da demora processual, não poderiam, só por si, justificar a antecipação de tutela, até porque são inevitáveis dentro do sistema do contraditório e ampla defesa. Logo, para a configuração do instituto, seria indispensável a ocorrência do risco de dano anormal, cuja consumação pudesse comprometer, substancialmente, a satisfação do direito subjetivo da parte.

Já a hipótese prevista no inciso II (abuso do direito de defesa ou manifesto propósito protelatório do réu) tinha como objetivo equalizar os males que o tempo pode causar ao processo, ou, como sustentado por Daniel Mitidiero ${ }^{32}$, visa promover a igualdade substancial entre as partes. Trata-se de expediente que tem como objetivo distribuir o peso que o tempo representa no processo de acordo com a maior ou menor probabilidade da posição jurídica afirmada pela parte ser fundada ou não.

Assim é que, quando o legislador instituiu a tutela antecipatória baseada em abuso do direito de defesa ou contra o manifesto propósito protelatório do réu, seu objetivo estava em evitar que o demandante fosse prejudicado, e o demandado beneficiado em idêntica medida, pelo tempo do processo. O legislador tratou o tempo do processo como fonte potencial de dano às partes, sugerindo a sua distribuição isonômica a fim de que não representasse prejuízo ao demandante que tem razão - que seria obrigado a suportá-lo integralmente - e benefício para o demandado que não a tem. (MITIDIERO, 2011, p. 169-171).

Verifica-se, pois, que na hipótese anterior (entenda-se, inciso I, do artigo 273, CPC), o juiz, ante o "fundado receio de dano irreparável ou de difícil reparação", concede a antecipação dos efeitos da tutela. Mas no caso do inciso II (entenda-se, abuso do direito de defesa ou manifesto propósito protelatório do réu), convencendo-se da verossimilhança do direito do autor, diante da prova de que o réu abusa do direito de defesa, ou comporta-se como "manifesto propósito protelatório", o legislador concedeu ao juiz a possibilidade de, igualmente, antecipar os efeitos da tutela pretendida pelo autor.

\footnotetext{
32 MITIDIERO, Daniel Francisco. Tendências em matéria de tutela sumária: da tutela cautelar à técnica antecipatória. Revista de Processo. vol. 197. p. 27-65. São Paulo: RT, Jul/2011. p. 169-171.
} 
Nessa situação, enunciou Ovídio Baptista da Silva ${ }^{33}$, que é evidente que o comportamento indesejável do réu faz presumir que ele não dispunha de nenhuma contestação séria a opor ao autor, razão pela qual, a hipótese comportaria a concessão da antecipação dos efeitos da tutela, porque a verossimilhança do direito do autor tornou-se ainda mais consistente ante a conduta do réu, sem que o juiz tenha necessariamente obrigado a funda-la nos pressupostos indicados pelo artigo 273, II, do CPC.

Saliente-se que, afora esses, também era necessário a presença de um requisito negativo, constante no $\S 2^{\circ}$, do artigo 273 , do CPC, o qual previa que não seria concedida a antecipação da tutela quando houvesse perigo de irreversibilidade do provimento antecipado.

Ao discorrer sobre o tema, João Batista Lopes ${ }^{34}$ teceu algumas críticas, como se observa de trecho de sua obra, transcrita a seguir:

Cabe registrar, à partida, a impropriedade técnica do dispositivo: o provimento antecipado (decisão interlocutória) é sempre reversível, seja porque cabível contra ele recurso (agravo de instrumento), seja porque, por sua natureza, a tutela antecipada é provisória e revogável. Diante disso, a quem interpretar o texto com os olhos voltados para a ratio legis: evitar que a concessão da tutela antecipada crie fato consumado e definitivo, sem possibilidade de retorno ao status quo ante. Cuida-se, portanto de irreversibilidade do provimento tout court. Como observa Marcacine, "é evidente que, quando se fala em reversibilidade, não se pode nem pensar em apenas duas situações, de modo que ou a medida seja reversível ou irreversível. É possível que a reversibilidade seja de difícil realização, ou demande tempo, dinheiro e muita atividade processual. Assim, é possível apurar no caso concreto o quanto a medida pode ser mais ou menos facilmente reversível.

Aliás, José Miguel Garcia de Medina $^{35}$ ensina que o requisito negativo previsto no $§ 2^{\circ}$, do artigo 273 não é concebido como uma regra absoluta, sobretudo porque não poderia o juiz amparar-se na simples possibilidade de irreversibilidade dos efeitos fáticos decorrentes da tutela antecipatória, a fim de escusar-se de exercer a função jurisdicional que lhe é atribuída. Segundo ele, o juiz deverá sopesar os argumentos e os valores jurídicos dos bens envolvidos e, então, determinar sua postura diante da situação.

\footnotetext{
${ }^{33}$ SILVA, Ovídio A. Baptista da. Curso de Processo Civil. 5. ed. São Paulo: RT, 2001, v. 1. p. $142-$ 143.

${ }^{34}$ LOPES, João Batista. Tutela antecipada. 4. ed. São Paulo: RT, 2009. p. 70.

${ }^{35}$ MEDINA, José Miguel Garcia de. A tutela antecipatória e o perigo de irreversibilidade do provimento. Revista de Processo. vol. 86. p. 24-34. São Paulo: RT, Abr - Jun/1997. p. 27.
} 
Vale dizer que, a teor do §4, do artigo 273, do Código de Processo Civil, a decisão que concedeu a antecipação dos efeitos da tutela antecipada poderia ser revogada ou modificada pelo magistrado a qualquer tempo, em decisão devidamente fundamentada.

No tocante a matéria, Calmon de $\operatorname{Passos}^{36}$ manifestou-se no sentido de conceder ao juiz a possibilidade de

tomar a iniciativa da revogação, desde que não se cuide de uma retratação do que antes decidiu, sim de uma avaliação de fatos novos ou novas provas que não puderam ser por ele consideradas quando da concessão da antecipação (...).

Por outro lado, segundo Teori Albino Zavascki (2008, p. 136), a reapreciação da tutela antecipada independia de fatos novos ou novas provas, ao passo que em se existindo novo juízo sobre a verossimilhança do direito, consubstanciado no aprofundamento da investigação probatória ou, ainda, pelo reexame da questão jurídica, em se convencendo o juiz da inverossimilhança total ou parcial do direito que antes lhe parecia verossímil (tanto que ensejou a antecipação da tutela), "então sim a medida poderá ser revogada inteiramente ou modificada parcialmente, de modo a adaptá-la à nova situação.”.

Com efeito, observa-se que com a positivação da antecipação de tutela no artigo 273, o processo cautelar voltou a ser utilizado apenas nos casos em que havia a necessidade de tutela para asseguramento, sendo reservada à tutela antecipada às hipóteses de antecipação dos efeitos da tutela final, com caráter satisfativo.

Posteriormente, com o advento da Lei n. ${ }^{\circ}$ 10.444/2002, o artigo 273 do Código de 1973 sofreu algumas alterações. Nesse aspecto, veja-se a redação do artigo $1^{\circ}$ da referida legislação:

Art. $1^{\circ}$ Os artigos da Lei no 5.869 , de 11 de janeiro de 1973 - Código de Processo Civil, a seguir mencionados, passam a vigorar com as seguintes alterações:

Art.273. (...)

$\S 3^{\circ} \mathrm{A}$ efetivação da tutela antecipada observará, no que couber e conforme sua natureza, as normas previstas nos arts. $588,461, \S \S 4^{\circ}$ e $5^{\circ}$, e $461-\mathrm{A}$.

(...)

$\S 6^{\circ} \mathrm{A}$ tutela antecipada também poderá ser concedida quando um ou mais dos pedidos cumulados, ou parcela deles, mostrar-se incontroverso.

\footnotetext{
${ }^{36}$ PASSOS, J. J. Calmon de. Comentários ao código de processo civil. 9. ed. Rio de Janeiro: Forense, 2004, v. 3. p. 69.
} 
$\S 7^{\circ}$ Se o autor, a título de antecipação de tutela, requerer providência de natureza cautelar, poderá o juiz, quando presentes os respectivos pressupostos, deferir a medida cautelar em caráter incidental do processo ajuizado. ${ }^{37}$

A toda a evidência a mais importante alteração implementada pela Lei $n .^{\circ}$ $10.444 / 2002$ se refere a inclusão do $\$ 7^{\circ}$, através do qual passou a ser prevista expressamente a possibilidade de fungibilidade entre as tutelas cautelares e a antecipação de tutela.

A título de esclarecimento são valorosas as lições de Sebastian Watenberg Ruanoba $^{38}$ sobre a inovação propiciada pelo sobredito disposto legal,

A fungibilidade técnica diz respeito ao preenchimento dos requisitos de uma ou outra tutela cuja fungibilidade se pretende, cautelar ou antecipatória. Ao aplicar o princípio da fungibilidade, deve o juiz observar se estão presentes os requisitos autorizadores da medida entendida como correta. Caso contrário, estará atentando o magistrado contra as diferenças existentes entre as tutelas cautelar e antecipatória. (...). Evidentemente, a regra da fungibilidade entre as tutelas antecipatória e cautelar não pode ser interpretada ao pé da letra do que dispõe o $§ 7 .^{\circ}$ do art. 273 do CPC. Assim, o novel instituto não só autoriza a concessão de tutela cautelar quando requerida tutela antecipatória, como também autoriza a concessão de tutela antecipatória quando requerida tutela cautelar. Não existe fungibilidade que comporte via única.

Assim, presentes os requisitos para a sua concessão a legislação concedeu ao magistrado o poder de deferir a tutela tecnicamente correta ao caso concreto, ainda que a parte tenha denominado a tutela sob outro nome.

\section{3}

\section{Comparativo: CPC de 1973 e CPC de 2015}

Em meados de 2010 a Comissão de Juristas responsável pelo anteprojeto do Código de Processo Civil entregou ao Senado o projeto do que viria a se tornar o Novo CPC, aprovado em 16 de março de 2015 e sancionado pela lei 13.105.

\footnotetext{
${ }^{37}$ BRASIL. Lei $\mathrm{n}^{\circ}$ 10.444, de 07 de maio de 2002. Altera a Lei $\mathbf{n}^{\mathbf{0}}$ 5.869, de 11 de janeiro de 1973 (Código de Processo Civil). Disponível em: <http://www.planalto.gov.br/Ccivil_03/leis/2002/L10444.htm>. Acesso em: 10 abr. 2018.

38 RUANOBA, Sebastian Watenberg. Fungibilidade das tutelas de urgência (antecipatória e cautelar) no processo civil brasileiro. Revista de Processo. vol. 148. p. 321-352. São Paulo: RT, Jun/2007. p. 340-342.
} 
Na exposição dos motivos, a Comissão enunciou quais foram os principais objetivos que permearam o estudo, dentre eles "simplificar, resolvendo problemas e reduzindo a complexidade de subsistemas, como, por exemplo, o recursal.". 39

Nesse particular, no que se refere à tutela provisória, para melhor entendimento das inovações trazidas como o novo sistema processual, faz-se necessário um retrospecto com o código de 1973.

Como se sabe, no Código de Processo Civil de 1973 a ação cautelar não resolvia litígios, mas resguardava determinada situação processual que tramitava em outra ação principal, notadamente diante de sua finalidade assecuratória, garantindo a efetividade de direitos. Vale ressaltar que nesse códex existiam as cautelares nominadas e as inominadas, que deveriam ser distribuídas em apartado da ação principal.

Para a concessão da tutela cautelar, a referida legislação exigia a existência de dois requisitos: o fumus boni juris (fumaça do bom direito) e o periculum in mora (perigo na demora da satisfação), de modo que caberia ao interessado demonstrar ao juízo que a demora na concessão do pedido poderia ocasionar danos irreparáveis acaso não concedido naquele momento processual. ${ }^{40}$

Por outro lado, no tocante a tutela antecipada inserida no artigo 273 do Código de Processo Civil de 1973, através da Lei n. ${ }^{\circ}$ 8.952/1994, foi instituída para que o autor alcançasse a pretensão deduzida na inicial, de forma temporária ou provisória, antes do provimento final. Da mesma forma, esse fenômeno jurídico veio para garantir que o processo alcançasse sua finalidade, liminarmente - tornando-a, ou não, definitiva na sentença -, assim como, para impedir a deturpação do uso da "cautelar inominada".

Outrossim, ao contrário das cautelares, a antecipação dos efeitos da tutela foi emparelhada ao processo de conhecimento.

Pois bem. O Código de Processo Civil de 1973 regulamentava a tutela de urgência de forma separada, isto é, em locais distintos. A tutela de urgência não satisfativa ("cautelar") era disciplinada pelo Livro III, que tratava do "processo

\footnotetext{
${ }^{39}$ FUX, Luiz. Comissão de Juristas Responsável pela Elaboração de Anteprojeto de Código de Processo Civil. Exposição de motivos do anteprojeto de código de processo civil de 2015. Disponível em: <http://www.senado.gov.br/senado/novocpc/pdf/Anteprojeto.pdf >. Acesso em: 11 mar. 2018.

${ }^{40}$ BUENO, Cassio Scarpinella. Curso sistematizado de direito processual civil: tutela antecipada, tutela cautelar e procedimentos cautelares específicos. 6. ed. São Paulo: Saraiva, 2014.
} 
cautelar", que dispunha sobre o dever-poder geral da cautela, a teoria geral da cautelar, as cautelares inominadas (atípicas) e as cautelares nominadas (típicas) em espécie. $^{41}$

O Livro I, regulava o "processo de conhecimento", e continha disposições sobre a tutela de urgência satisfativa ("antecipada") no artigo 273 (com redação dada pelas Leis 8.952/1994 e 10.444/2002). Em outros termos, a lei 8.952 sancionada em 1994 alterou o CPC/73 e, dentre outras mudanças, institucionalizou no Brasil a tutela antecipada generalizada passando a dispor no caput do art. 273, livro I "Do Processo de Conhecimento", que o juiz poderia, então, deferir pedido da parte para antecipar os efeitos da tutela final, desde que preenchidos alguns pressupostos: a existência de prova inequívoca de seu direito, apta a convencer da verossimilhança das suas alegações, somado ao receio de dano ou ao abuso de defesa do réu. A antecipação dos efeitos da tutela surgiu, então, de forma generalizada no sistema brasileiro em 1994, como satisfação provisória do direito.

Por outro lado, analisando as reformas efetivadas pelo Código de Processo Civil de 2015 no que tange as tutelas provisórias, percebe-se, de início, que há um título específico que as ordena, e são divididas em duas espécies: tutela de urgência - antecipatória e cautelar - e a tutela de evidência.

Logo, com o Novo Código, as tutelas de urgência passam a ter tratamento de forma conjunta e, mesmo com a extinção do processo cautelar, poderão ser concedidas a qualquer tempo no processo.

Assim é que uma das principais diferenças no aspecto das tutelas de urgência contidas no Código de Processo Civil de 1973 com o Código de Processo Civil de 2015 é a extinção do livro de processo cautelar. Sem embargo, restou apenas a tutela cautelar, que foi inserida na parte geral da nova legislação, frisando que tais institutos foram inseridos no Livro V do CPC, que possui o seguinte título: "Da Tutela Provisória".

Com efeito, o novo Código de Processo Civil extinguiu o processo cautelar. Todavia, pode-se afirmar que manteve algumas cautelares nominadas, tais como o sequestro, o arresto, o arrolamento de bens, o registro de protesto contra alienação

${ }^{41}$ REDONDO, Bruno Garcia. Estabilização, modificação e negociação da tutela de urgência antecipada antecedente: principais controvérsias. Revista de Processo. v. 244, a. 40. São Paulo: RT, jun. 2015. p. 167-194. 
de bem e qualquer outra medida idônea para asseguração do direito previsto no art. 301.

Ademais disso, vê-se que o novo Código também trouxe a possibilidade de que a tutela antecipatória possa ser requerida de forma antecedente e/ou incidental. Nesse contexto, considerando que tais institutos serão abordados em capítulo específico ao longo desse trabalho, importa apenas adiantar que esse tipo de tutela de urgência exige a ausência do perigo de irreversibilidade dos efeitos da decisão, conforme dispõe o $\$ 3^{\circ}$, do artigo 300, do CPC/2015, segundo o qual:

Art. 300. (...)

$\S 3^{\circ}$. A tutela de urgência de natureza antecipada não será concedida quando houver perigo de irreversibilidade dos efeitos da decisão.

Decerto, em que se pese a simplificação dos pressupostos e requisitos para a concessão da antecipação da tutela, o que se percebe é que esta permanece condicionada a satisfação de requisitos, e, ainda, preserva sua essência, ou seja, a entrega provisória do direito postulado pela parte.

Outrossim, outra relevante e importante inovação existente no Código de Processo Civil de 2015 está relacionada ao instituto da tutela da evidência, que, igualmente, a ser melhor discorrida ao longo do presente trabalho, é aquela que se baseia na demonstração, pelo requerente, de um direito líquido e certo, que apresente evidência em suas alegações, munida de prova inequívoca. A tutela da evidência, como espécie do gênero tutela provisória, foi inserida através dos arts. 294 e 311.

Em suma, o CPC/15 unifica, sob um mesmo regime (tutela provisória), as tutelas de urgência e de evidência. E também sob a mesma disciplina de tutela de urgência as tutelas cautelares e antecipadas. Dessa vez extirpando do código processual as cautelares típicas, trazendo apenas os pressupostos genéricos para concessão de qualquer medida cautelar: periculum in mora e aparência do bom direito.

Nesse aspecto, saliente-se que a Comissão de Juristas envolvida na elaboração do Novo CPC justificou a alteração dos institutos da tutela cautelar e antecipada em face da necessidade de celeridade e eficiência processual.

A conta disso vê-se que o Código de Processo Civil de 2015 tratou do tema tutela provisória de maneira significativamente diferente, ao passo que, como enunciado pelo professor Bruno Garcia Redondo (2015, p. 167-194), as principais 
inovações dessa matéria levadas a efeito pelo novo códex se resumem a: a extinção do Livro especificamente destinado ao "processo cautelar", eis que não há no novo Código qualquer correspondência ao Livro III do CPC/1973; extinção da regulamentação de todas as cautelares nominadas/típicas (em espécie); consagração de cláusula geral de atipicidade das medidas cautelares, decorrente da manutenção do dever-poder geral de cautela do juiz (art. 297); unificação do regime da "tutela provisória” (art. 294 e ss.), que se tornou o gênero de 02 (duas) espécies (tutelas de "urgência" e da "evidência"); unificação do regime da tutela de urgência, com tratamento conjunto das tutelas "antecipada" e "cautelar" (arts. 300 a 310), inclusive no que se refere aos seus pressupostos/requisitos e a fungibilidade; criação da tutela antecipada antecedente (arts. 303 e 304), com a possibilidade de estabilização dos seus efeitos; ampliação das hipóteses de tutela "da evidência" (art. 311); criação do julgamento "antecipado" (rectius: imediato) parcial de mérito (art. 356), ainda que a sentença seja recorrível por agravo de instrumento (art. 356, §5º), com possibilidade de formação de coisa julgada material e execução definitiva (art. $356, \S^{\circ}$ ) na hipótese de não interposição de recurso. 


\section{3 \\ A tutela provisória no Código de Processo Civil de 2015}

\section{1 Definição e alcance da tutela provisória}

Como se sabe, o instituto denominado de "Tutelas Provisórias" foi objeto de inúmeras alterações no decorrer da tramitação no Senado Federal e na Câmara dos Deputados, culminando com a elaboração de Projetos de Leis que originaram o Código de Processo Civil de 2015.

Nesse sentido, dispunha o artigo 277 do Projeto de Lei n. ${ }^{\circ}$ 166/2010, que "A tutela de urgência e a tutela de evidência podem ser requeridas antes ou no curso do procedimento, sejam essas medidas de natureza cautelar ou satisfativa".

No entanto, com o advento do Projeto Substitutivo apresentado pela Câmara dos Deputados (PLC 8.046/2010) pretendeu-se conferir à tutela antecipada nova moldagem, o que importaria na reformulação da acepção firmada no CPC/1973. Foi assim que seu artigo 295 passou a disciplinar a matéria, nos termos seguintes:

A tutela antecipada, de natureza satisfativa ou cautelar, pode ser concedida em caráter antecedente ou incidental.

Parágrafo único. A tutela antecipada pode fundamentar-se em urgência ou evidência.

Por conta da redação em questão, muito se discutiu na doutrina sobre a superação da dicotomia existente entre a tutela cautelar e a tutela antecipada, ora para estabelecer distinções, ora para a identificação de semelhanças. Sobre o assunto, Eduardo Cambi e Aline Regina das Neves explicam que:

(...) Assim, vislumbrava-se superar a dicotomia existente entre a tutela cautelar e a tutela antecipada, sobre a qual a doutrina debruçou-se ora para estabelecer distinções, ora para identificar os pontos de contato. A superação da dicotomia, contudo, restringia-se ao aspecto técnico, já que, em razão da redação do artigo 295, do Projeto Substitutivo (PLC 8.046/2010), não se podia inferir que se tivesse extirpado do ordenamento a tutela cautelar, mas tão-somente, unificado a técnica disponibilizada para sua obtenção. ${ }^{42}$

\footnotetext{
${ }^{42}$ CAMBI, Eduardo; NEVES, Aline Regina das. Acesso à justiça, tutela antecipada e técnicas processuais. In: DIDIER JR., Fredie; FREIRE, Alexandre; MACÊDO, Lucas Buril de; PEIXOTO, Ravi (Orgs.). Procedimentos especiais, tutela provisória e direito transitório. Coleção Novo CPC. Doutrina Selecionada. 2. ed. Salvador: Juspodivm, 2016, v. 4. p. 118.
} 
Em todo o caso, no final o texto legal do PLC 8.046/2010 (Projeto Substitutivo) foi alterado, e, sem que houvesse modificação substancial no conteúdo das suas disposições, passou a prever no Código de Processo Civil de 2015 o Livro V, que viria a tratar sobre a "Tutela Provisória" - em substituição à terminologia "Tutela Antecipada" -, gênero em que são espécies as "Tutelas de Urgência" - de natureza cautelar ou antecipada - e a "Tutela da Evidência", sendo esta última uma inovação, não prevista no Código de 1973.

Vê-se, pois, que sob a denominação de "tutela provisória", o Código de Processo Civil de 2015, no seu Livro V reuniu institutos distintos não mais reservando um livro exclusivo ao processo cautelar, cuja tutela, agora, também está prevista conjuntamente com técnicas processuais que possuem como base a urgência ou a evidência.

O novo CPC, portanto, reserva a expressão "tutela provisória" para sistematizar a tutela jurisdicional cautelar, a técnica da antecipação da tutela e a tutela da evidência. ${ }^{43}$

Assim é que a tutela provisória pode ser definida como uma espécie de tutela jurisdicional, entendida esta como "tipo de provimento"44, ou, uma tutela em sentido estrito, assegurando à parte o alcance do bem da vida pretendido. Em outros termos, se configura como uma tutela que, em razão da sua natural limitação cognitiva, não é apta a prover definitivamente sobre o interesse no qual incide e que, nessa condição, sem prejuízo da sua imediata eficácia, poderá, a qualquer momento, ser modificada ou vir a ser objeto de um provimento definitivo em um procedimento de cognição exaustiva. ${ }^{45}$

Destarte, em que se pese a terminologia "tutela provisória" utilizada pelo legislador, há quem a critique, ao fundamento de que seu emprego deixa na sombra aquilo que mais interessaria para quem se utiliza das vias judiciais: a busca pela

\footnotetext{
${ }^{43}$ GODINHO, Robson Renault. Comentários aos artigos 294 a 311. In CABRAL, Antonio do Passo; CRAMER, Ronaldo (Coord). Comentários ao novo Código de Processo Civil. 2. ed. Rio de Janeiro: Forense, 2016. p. 458.

${ }^{44}$ CONCEIÇÃO, Maria Lúcia Lins; MELLO, Rogerio Licastro Torres de; RIBEIRO, Leonardo Ferres da Silva; WAMBIER, Teresa Arruda Alvim. Primeiros comentários ao novo código de processo civil. São Paulo: RT, 2015.

${ }^{45}$ GRECO, Leonardo. A tutela da urgência e a tutela da evidência no código de processo civil de 2015. In: DIDIER JR., Fredie; FREIRE, Alexandre; MACÊDO, Lucas Buril de; PEIXOTO, Ravi (Orgs.). Procedimentos especiais, tutela provisória e direito transitório. Coleção Novo CPC. Doutrina Selecionada. 2. ed. Salvador: Juspodivm, 2016, v. 4. p. 186.
} 
tutela do direito. Nesse sentido, Luiz Guilherme Marinoni, Sergio Cruz Arenhart e Daniel Mitidiero ao afirmarem que:

(...) Ao falar em tutelas provisórias o legislador imagina mais uma vez - voltando mais de cem anos na história do processo civil - que é possível tratar o direito material com uma categoria interna, única e invariável que não nos fornece qualquer pista a respeito dos pressupostos materiais que devem ser alegados e provados para proteção do direito material. ${ }^{46}$

Para esses autores, ao fazer a alusão às "tutelas provisórias”, sem iluminá-las com o conceito de tutela de direitos, o legislador perdeu de vista aquilo que a parte efetivamente vai procurar no processo, que é a prestação adequada, efetiva e tempestiva da tutela jurisdicional dos direitos.

Da mesma maneira, Fredie Didier Júnior, Paula Sarno Braga e Rafael Alexandria de Oliveira criticam a terminologia utilizada no texto final do Código de 2015. Segundo eles,

(...) quando o referido projeto voltou para o Senado, substituiu-se o termo 'Tutela Antecipada' por 'Tutela Provisória', reservando-se a expressão 'Tutela Antecipada' exclusivamente para aquelas tutelas provisórias de caráter satisfativo. Não foi a opção mais adequada, (...) pois não há uma tutela antecipada definitiva, que se oporia à tutela antecipada provisória. Antecipar é técnica. Satisfazer tem a ver com o tipo de tutela. A tutela provisória é, isso sim, uma técnica processual de antecipação provisória dos efeitos finais da tutela definitiva, sendo esta última (a tutela definitiva) a única que goza da autonomia necessária para ser designada de 'tutela', representando funções jurisdicionais próprias de certificação, a efetivação e o acautelamento do direito. E essa tutela antecipada tanto pode ser satisfativa como não satisfativa. (DIDIER JR.; BRAGA; OLIVEIRA, 2016, P. 581).

Inobstante as críticas, não se pode negar a importância da tutela provisória para a adequada distribuição do ônus do tempo no processo. Para Humberto Theodoro Júnior ${ }^{47}$ representam provimentos imediatos que podem, de alguma maneira, minimizar os inconvenientes suportados pela parte que invoque a tutela de um direito consagrado pela ordem jurídica material (fumus boni iuris), e têm em comum a meta de combater os riscos de injustiças ou de danos decorrentes da demora na solução do conflito submetido ao crivo do Poder Judiciário.

\footnotetext{
${ }^{46}$ MARINONI, Luiz Guilherme; ARENHART, Sérgio Cruz; MITIDIERO, Daniel. O novo processo civil. 3. ed. São Paulo: RT, 2017. p. 231.

${ }^{47}$ THEODORO JR., Humberto. Curso de direito processual civil: Teoria geral do processo civil, processo de conhecimento e procedimento comum. 57. ed. Rio de Janeiro: Forense, 2016, v. 1. p. 610-611.
} 
Destarte, o termo tutela provisória deve ser complementado pela ideia de tutela definitiva, pois ao se considerar que uma decisão é provisória sabe-se que será substituída por outra. Ou, como destacado pelo professor Fred Didier (2016, p. 582), “por ser provisória, será substituída por uma tutela definitiva, que a confirme, revogue ou modifique.”.

Ressalte-se que a tutela definitiva é aquela obtida após todo o trâmite processual, em cognição exauriente, “(...) com profundo debate acerca do objeto do processo, garantindo-se o devido processo legal, o contraditório e a ampla defesa." (DIDIER JR.; BRAGA; OLIVEIRA, 2016, p. 575). Ademais, é predisposta a produzir resultados imutáveis, cristalizados pela coisa julgada material.

Diferentemente, a decisão que concede a tutela provisória é baseada em cognição sumária e dá eficácia imediata à tutela definitiva pretendida. Tem-se que as tutelas provisórias são as tutelas jurisdicionais não definitivas, fundadas em cognição sumária, isto é, fundadas em um exame menos profundo da causa, capaz de levar a prolação de decisões baseadas em juízo de probabilidade e não de certeza. $^{48}$

Nesse aspecto, nas lições de Kazuo Watanabe ${ }^{49}$ extrai-se que cognição é técnica de conhecimento, pois através da análise do processo - valoração das alegações, provas produzidas, etc. - poderá o juiz formar juízos de valor com o fito de decidir as questões suscitadas. Para ele, inclusive, a cognição pode ser dividida em dois planos: vertical e horizontal. ${ }^{50}$

Cognição, dessa forma, é o conhecimento do juiz perante o processo, que pode ser exauriente - isto é, um conhecimento mais completo - ou sumária - um conhecimento mais superficial -, frisando que ambas as cognições são observadas no plano vertical. Cognição sumária, em outras palavras, “(...) é aquela que conduz o magistrado a um juízo de probabilidade". ${ }^{51}$

\footnotetext{
${ }^{48}$ CÂMARA, Alexandre Freitas. O novo processo civil brasileiro. São Paulo: Atlas, 2015.

${ }^{49}$ WATANABE, Kazuo. Da cognição no processo civil. 4. ed. São Paulo: Saraiva, 2012.

${ }^{50}$ No plano horizontal a cognição terá como limites os elementos objetivos do processo, e, nessa condição, poderá ser plena ou limitada, a depender do seu alcance. Por sua vez, no plano vertical a cognição se dará conforme o grau de profundidade, de modo que quanto mais profunda, mais completa (exauriente) será; e quanto mais superficial, mais incompleta (sumária).

${ }^{51}$ KOEHLER, Frederico Augusto Leopoldino; MIRANDA, Gabriela Expósito Tenório. Estabilização da tutela antecipada antecedente: tentativa de sistematização. In: DIDIER JR., Fredie. Tutela provisória. Salvador: Juspodivm, 2016. p. 75.
} 
A vista disso, a doutrina atribui à tutela provisória duas características essenciais: a sumariedade do procedimento e a provisoriedade da tutela.

A sumariedade pode adotar duas roupagens diversas: substancial ou processual. A primeira tem como objetivo simplificar o rito, sem, contudo, abdicar da finalidade de compor o mérito definitivamente (ex. - mandado de segurança; ação de busca e apreensão e ações nos juizados especiais). Nesse caso, haveria a formação de coisa julgada, "uma vez que a solução do litígio se dá de maneira satisfativa e exauriente." (THEODORO JR., 2016, p. 617).

No que tange a sumariedade processual tem como escopo simplificar o procedimento apenas para atender a uma emergência do caso concreto, sem a pretensão de dar uma solução definitiva ao litígio. A solução dada a hipótese é precária, portanto destinada a durar apenas enquanto aguarda a futura solução definitiva do litigio, razão pela qual não há que se falar em formação da res iudicata.

Para Fredie Didier Júnior, Paula Braga e Rafael Oliveira (2016, p. 582) a sumariedade processual seria o que eles intitulam de "sumariedade da cognição", que, complementando a lição de Humberto Theodoro Junior é tratada como uma característica atribuída à tutela provisória, porque a decisão sob essa ótica se assenta em análise superficial do objeto litigioso, autorizando que o julgador decida a partir de um juízo de probabilidade.

Por outro norte, quanto à provisoriedade, as tutelas provisórias são assim referidas por não se revestirem de caráter definitivo, se destinando a durar por um espaço de tempo delimitado. Ou seja, essa provisoriedade significa que as tutelas têm duração temporal limitada àquele período de pendência do processo (art. 296, CPC/2015), conservando sua eficácia também durante o período de eventual suspensão da ação, salvo decisão judicial em contrário (art. 296, parágrafo único, CPC/2015). Ou, como sustentado por Eduardo Scarparo ${ }^{52}$ :

Assinalada por Calamandrei, a diferença se dá porque o temporário é tão somente o
que não dura para sempre, ao passo que o provisório é aquilo que é feito para ser
substituído por algo definitivo. Lopes da Costa ofereceu elucidativo exemplo: os
andaimes em uma obra são temporários, pois persistirão durante o período em que
necessários para o alcance de suas próprias finalidades. Serão, também, definitivos,
"no sentido de que nada virá substituí-los", muito embora não se eternizem. Por outro
lado, a barraca usada para habitação enquanto a construção não termina é provisória,

52 SCARPARO, Eduardo. A supressão do processo cautelar como tertium genus no código de processo civil de 2015. In: BOECKEL, Fabrício Dani de; ROSA, Karin Regina Rick; SCARPARO, Eduardo (Orgs.). Estudos sobre o novo código de processo civil. Porto Alegre: Livraria do Advogado, 2015. p. 127. 
já que ela será trocada pela morada definitiva, justificando-se tão somente em razão da ainda inexistência desta.

Isso é o que Fred Didier (2016, p. 582) denomina como precariedade, característica essa que permite à decisão proferida em sede de tutela provisória conservar sua eficácia ao longo do processo, ressalvada a possibilidade de decisão judicial em sentido contrário (art. 296, parágrafo único, CPC).

Nesse particular, é oportuno lembrar que por estarem sujeitas ao regime do cumprimento provisório da sentença (art. 297, parágrafo único), revestindo-se do caráter de solução não definitiva, essas tutelas são passíveis de revogação ou modificação, a qualquer tempo (art. 296), mas sempre por meio de decisão fundamentada (art. 298).

Em todo o caso, adverte o ilustre Ministro Teori Albino Zavascki (2008, p. 35-36), seguido por Fred Didier (2016, p. 599), que a revogação ou modificação da tutela provisória só poderá se dar em razão de uma alteração no estado de fato ou de direito ou do estado de prova - quando, por exemplo, na fase de instrução, restarem evidenciados fatos que não correspondam àqueles que autorizaram a concessão da tutela.

Não obstante isso, em sentido contrário, Leonardo Greco entende que basta "o simples reexame pelo juiz dos fatos e circunstâncias apreciados por ocasião da concessão." 53

Pois bem. Ultrapassadas as divergências quanto ao seu conceito e características, é importante destacar que, no que tange a legitimidade para requerer a antecipação provisória dos efeitos da tutela jurisdicional, essa pode ser atribuída a todo aquele que invoca o reconhecimento do direito a satisfação de sua pretensão, uma vez que, para a doutrina, a tutela jurisdicional pode ser encarada como resultado prático favorável proporcionado a quem tenha razão, obtido após o exercício da função jurisdicional (DIDIER JR.; BRAGA; OLIVEIRA, 2016, p. 587).

Nesse prisma, uma vez preenchidos os pressupostos estabelecidos pela legislação, podem requerer a antecipação provisória dos efeitos da tutela (satisfativa

\footnotetext{
${ }^{53}$ GRECO, Leonardo. A tutela de urgência e a tutela de evidência no código de processo civil de 2014/2015. Revista Eletrônica de Direito Processual. v. XIV, ano 8, jul-dez. 2014. p. 306.
} 
ou cautelar): autor; réu ${ }^{54}$;terceiros intervenientes (que se tornam partes a partir da intervenção); assistente simples (condicionado à vontade do assistido); substituto processual (legitimado a defender o direito de outrem); e Ministério Público (na qualidade de parte ou de assistente diferenciado de incapazes). Na tutela provisória em caráter antecedente, em razão do próprio procedimento, em que é especificado o requerimento através da petição inicial (artigos 303 e 305), a legitimidade é restrita à figura do Autor. (DIDIER JR.; BRAGA; OLIVEIRA, 2016, p. 587-589).

Ademais disso, no tocante ao seu cabimento, admite-se a tutela provisória no procedimento comum do CPC (art. 318, CPC); no procedimento dos Juizados Especiais Cíveis; nos procedimentos especiais (art. 318, parágrafo único, CPC); e nos procedimentos especiais de jurisdição voluntária.

Todavia, é oportuno enfatizar, a título de breve nota, que muito se discute na doutrina sobre a possibilidade de, em tais procedimentos especiais que contam com a tutela provisória com pressupostos específicos, ser cabível a tutela provisória fundada nos pressupostos genéricos do Livro V, do CPC.

$\mathrm{Na}$ opinião de Arlete Inês ${ }^{55}$, às liminares a serem concedidas nos procedimentos especiais, que possuírem requisitos e procedimentos próprios, não podem ser aplicadas as disposições que regem as tutelas provisórias, impedindo, por exemplo, que venham a se tornar estáveis. Segundo essa doutrinadora,

É importante partir da noção geral de que há procedimentos diferenciados no código,
nos quais são previstas liminares, para que se possa de antemão ter presente que,
quando constar previsão de liminar específica para um procedimento especial é este
que deve ser observado e não o procedimento das tutelas provisórias. O mesmo se
diga de procedimentos especiais previstos em leis extravagantes. A liminar neles
previstas continua ter seu regramento específico previsto na legislação de regência.
(...) chegamos ao novo CPC, em que temos a previsão das tutelas provisórias de
urgência e as de evidência, em capítulo próprio e temos também as liminares
previstas em procedimentos especiais, inclusive em legislação extravagante, que
continuam mantidas. Penso que quando houver essa previsão, devesse seguir o
modelo apresentado nesse procedimento. Portanto, a liminar a ser deferida nos
procedimentos especiais que tenha estabelecido requisitos e procedimento específico
para tanto, não se regem pelo art. 294 e segs. do Novo CPC que cuida das tutelas
provisórias. Por exemplo, não há que se falar em estabilização para os casos de tutela

${ }^{54} \mathrm{O}$ réu pode requerer a tutela provisória quando for reconvinte e denunciante; quando formular pedido contraposto; ou quando a ação for dúplice, na medida em que sua defesa já se constitui o exercício de sua pretensão.

55 AURELLI, Arlete Inês. Liminares nos procedimentos especiais e o novo CPC. 2016. In: SCARPELLI, Natália Calçado. Estabilização da tutela provisória de urgência antecipada requerida em caráter antecedente. 2016. 186 f. Dissertação (Mestrado em Direito Processual Civil) - Pontifícia Universidade Católica de São Paulo (PUC-SP), São Paulo, 2016. p. 62. 
que tenha natureza de tutela antecipada, se se tratar de uma previsão específica para um procedimento especial.

Não obstante, ela admite ressalvas, notadamente quando as normas que regulam os procedimentos especiais sejam omissas; quando, ainda que não omissas, houver previsão específica de tutela provisória; ou na hipótese da parte não satisfazer os requisitos necessários a concessão de liminar específica.

Decerto, esse é o caso das possessórias. Por isso, Fred Didier (2016, p. 590) a afirmar que nas ações possessórias de força velha - assim entendidas como as propostas depois de ano e dia, contados do esbulho ou da turbação - , seguindo a letra do artigo 558, parágrafo único, do CPC, é admissível a tutela provisória satisfativa genérica, desde que preenchidos os pressupostos legais genéricos.

Com relação a tutela provisória nos procedimentos especiais de jurisdição voluntária, é de se ressaltar que seu cabimento também enseja debates doutrinários. Mas, utilizando como exemplo a nomeação de um curador provisório para o interditando, no procedimento de interdição ou de remoção de curador, alguns estudiosos admitem sua utilização ${ }^{56}$, ao fundamento de que "basta que sejam preenchidos os pressupostos legais", na medida em que "são procedimentos que exaurem seus efeitos na sua própria concretização.”.

Por fim, sobre o cabimento de recursos, é importante que essa análise seja feita em detrimento do momento processual em que concedida, denegada ou modificada, ou, ainda, sob o aspecto do órgão judicial que a prolatou.

Assim é que em sendo proferida por um juiz singular, o recurso cabível para impugná-la é o agravo de instrumento, na forma do artigo 1.015 , I, do $\mathrm{CPC}^{57}$, visto tratar-se de uma decisão interlocutória.

Por outro norte, se a tutela for concedida, confirmada ou revogada em sede de sentença, caberá o recurso de apelação sem efeito suspensivo, em conformidade com o que estabelece o artigo $1.012, \S 1^{\circ}, \mathrm{V}, \mathrm{CPC}^{58}$.

\footnotetext{
${ }^{56}$ GRECO, Leonardo. Jurisdição voluntária moderna. São Paulo: Dialética. 2003. p.52.

${ }^{57}$ Art. 1.015. Cabe agravo de instrumento contra as decisões interlocutórias que versarem sobre: I - tutelas provisórias;

${ }^{58}$ Art. 1.012. A apelação terá efeito suspensivo. § 1o Além de outras hipóteses previstas em lei, começa a produzir efeitos imediatamente após a sua publicação a sentença que: V - confirma, concede ou revoga tutela provisória;
} 
Doutra feita, se concedida pelo Tribunal, poderá assumir duas feições. $\mathrm{Na}$ primeira, será a tutela provisória concedida por um membro do Tribunal, e essa decisão admite ser enfrentada por agravo interno (art. 1.021, CPC ${ }^{59}$ ); Já na segunda, poderá ser concedida por acórdão, não sujeito a recurso extraordinário, por força do enunciado n. 735 do Colendo Supremo Tribunal Federal ${ }^{60}$, entretanto sendo admitida a via do recurso especial, com vistas a discussão do preenchimento dos pressupostos da concessão da medida, a teor do decidido pela $1^{\text {a }}$ Turma do Superior Tribunal de Justiça, no REsp n. ${ }^{\circ}$ 816.050/RN, de relatoria do Exm ${ }^{\circ}$ Sr. Ministro Teori Albino Zavascki, julgado em 28.03.2006, publicado no DJ de 10.04.2006, p. $163 .^{61}$

\section{2}

\section{Fundamentos da Tutela provisória: urgência ou evidência}

O artigo $294^{62}$, do livro $\mathrm{V}$, parte geral, do CPC/15, dispõe que a tutela provisória poderá fundamentar-se em urgência ou evidência.

Desse modo, com o intuito de melhor compreendermos o enquadramento dessas espécies de tutelas provisórias, resta imprescindível uma comparação detalhada entre essas medidas inseridas no Livro V do Código de 2015. Portanto, em um primeiro momento serão analisadas as tutelas de urgência e, em seguida, as de evidência.

\footnotetext{
${ }^{59}$ Art. 1.021. Contra decisão proferida pelo relator caberá agravo interno para o respectivo órgão colegiado, observadas, quanto ao processamento, as regras do regimento interno do tribunal.

60 "Não cabe recurso extraordinário contra acórdão que defere medida liminar.".

61 "EMENTA PROCESSUAL CIVIL. RECURSO ESPECIAL. MEDIDA LIMINAR EM AÇÃO CAUTELAR. ANÁLISE DO MÉRITO DA DEMANDA. IMPOSSIBILIDADE. VIOLAÇÃO AO ART. 535 DO CPC. INOCORRÊNCIA. 1. Em recurso especial contra acórdão que nega ou concede medida cautelar ou antecipação da tutela, a questão federal passível de exame é apenas a que diz respeito aos requisitos da relevância do direito e do risco de dano, previstos nos artigos 804 e 273 do CPC. Não é apropriado invocar, desde logo, e apenas, ofensa às disposições normativas relacionadas com o mérito da ação principal. 2. Não viola o art. 535 do CPC, nem importa negativa de prestação jurisdicional, o acórdão que, mesmo sem ter examinado individualmente cada um dos argumentos trazidos pelo vencido, adotou, entretanto, fundamentação suficiente para decidir de modo integral a controvérsia posta. 3. Recurso especial parcialmente conhecido e, nesta parte, improvido.".

${ }^{62}$ Art. 294. A tutela provisória pode fundamentar-se em urgência ou evidência.
} 


\subsection{1}

\section{Tutela provisória de urgência}

As tutelas provisórias de urgência encontram-se previstas no Título II, do Livro V, do Código de 2015, que se subdivide em três capítulos: "I - Disposições Gerais", "II - Do Procedimento da Tutela Antecipada Requerida em Caráter Antecedente" e "III - Do Procedimento da Tutela Cautelar Requerida em Caráter Antecedente".

Em situação de urgência, o tempo despendido para a obtenção da tutela definitiva poderá colocar em risco a efetividade do direito, de modo que no intuito de abrandar os efeitos prejudiciais do tempo do processo, o legislador instituiu a técnica de antecipação provisória dos efeitos finais da tutela definitiva, permitindo, pois, a usufruição antecipada e imediata dos seus efeitos.

Com efeito, nos termos do que dispõe o art. 294, parágrafo único do CPC, a tutela de urgência pode ser cautelar ou satisfativa (esta também conhecida como tutela antecipada de urgência), ao passo que para ambas as modalidades estabelece o CPC/15, no seu artigo $300^{63}$, requisitos essenciais para sua concessão. São eles: a probabilidade do direito - tradicionalmente conhecida como fumus boni iuris - e o perigo de dano ou risco ao resultado útil do processo - isto é, o periculum in mora.

A probabilidade do direito a ser provisoriamente satisfeito ou acautelado se caracteriza como a plausibilidade da existência do direito alegado pelo demandante, ao passo que, para sua aferição, deverá o magistrado avaliar se há elementos que evidenciem a probabilidade do fato narrado ter acontecido, e, ainda, quais seriam as chances de êxito acaso deferida a tutela.

Por isso, é necessária a existência de uma verossimilhança fática, ou seja, a constatação de que há uma verdade provável sobre os fatos, independentemente da produção de provas ${ }^{64}$, e, ainda, de uma plausibilidade jurídica, com a consequente verificação de que é provável a subsunção dos fatos à norma invocada, conduzindo aos efeitos pretendidos. ${ }^{65}$

\footnotetext{
${ }^{63}$ Art. 300. A tutela de urgência será concedida quando houver elementos que evidenciem a probabilidade do direito e o perigo de dano ou o risco ao resultado útil do processo.

${ }^{64}$ BEDAQUE, José Roberto dos Santos. Tutela cautelar e tutela antecipada: tutelas sumárias e de urgência. 3. ed. São Paulo: Malheiros, 2003. p. 336.

${ }^{65}$ CARNEIRO, Athos Gusmão. Da antecipação de tutela. 5. ed. Rio de Janeiro: Forense, 2004. p. 28.
} 
No que tange ao periculum in mora, pressupõe a existência de elementos que evidenciem o perigo que a demora na prestação da tutela jurisdicional pode representar para a efetividade da jurisdição e a eficaz realização do direito. Este perigo pode ter por alvo a própria existência do direito material - caso em que será adequada a tutela de urgência satisfativa - ou a efetividade do processo - hipótese em que será adequada a tutela cautelar.

Em todo o caso, é imprescindível que se perceba que o nível de profundidade da cognição a ser desenvolvida pelo juiz para se pronunciar sobre o requerimento de tutela provisória de urgência será semelhante, tanto em relação a medida de natureza cautelar quanto a de natureza satisfativa.

Em outras palavras, será o tipo de perigo existente que vai facilitar a distinção das hipóteses de cabimento de um instituto em detrimento do outro, ou seja: em havendo risco de que a demora do processo produza dano ao direito material, cabível será a tutela de urgência satisfativa; mas, em se existindo risco de que a demora do processo resulte dano para sua efetividade, caberá tutela de urgência cautelar.

Com efeito, para Athos Gusmão Carneiro (2004, p. 28), o que justifica a tutela provisória de urgência é o perigo de dano, que enumerado por Teori Zavascki (2008, p. 77) pode ser: concreto (certo), e não hipotético ou eventual, decorrente de mero temor subjetivo da parte; atual, ou seja, estando na iminência de ocorrer, ou que esteja ocorrendo; e grave, sendo de grande ou média intensidade, tendo aptidão para prejudicar ou impedir a fruição do direito.

Pois bem. Além dos requisitos da probabilidade de existência do direito e perigo de dano iminente, a tutela de urgência satisfativa exige outro requisito para ser concedida. Trata-se de um requisito negativo, previsto no artigo $300, \S 3^{\circ}$, que assim dispõe: "a tutela de urgência de natureza antecipada não será concedida quando houver perigo de irreversibilidade dos efeitos da decisão.”.

Porquanto, não se admite a tutela de urgência satisfativa que seja capaz de produzir efeitos irreversíveis. Exige-se, pois, que os efeitos da tutela provisória sejam reversíveis, sendo possível que retorne ao status quo ante caso se verifique, no curso do processo, que deva ser a decisão que a deferiu alterada ou revogada.

Decerto, essa característica tem uma razão de ser. A tutela provisória satisfativa (antecipada) é concedida com base em cognição sumária. Desse modo, não se revela compatível com esse provimento a produção de resultados definitivos, 
irreversíveis, até porque, acaso ela não seja confirmada ao final do processo, o ideal será que retorne ao status quo ante, sem impor prejuízo a parte adversária.

Assim é que deferir uma tutela provisória satisfativa irreversível seria o mesmo que conceder a própria tutela definitiva, o que, sob a crítica do ilustre Ministro Teori Zavascki (2008, p. 97), representaria a antecipação da própria vitória definitiva do autor, sem, contudo, assegurar ao réu o devido processo legal e o contraditório, ao passo que "ante a irreversibilidade da situação de fato, tornar-seia absolutamente, inútil, como inútil seria, nestes casos, o prosseguimento do próprio processo.”.

Por outro lado, em qualquer de suas modalidades (cautelar ou satisfativa), o artigo $300, \S 1^{\circ}$, do $\mathrm{CPC}^{66}$ estabelece que a concessão da tutela provisória de urgência, exigirá a prestação de uma caução de contracautela, que poderá ser real ou fidejussória, com vistas a proteção da parte contrária contra o risco de que venha a sofrer danos indevidos, configurando-se, pois, como um modo de prover meios de reversibilidade, ainda que través de reparação pecuniária.

Deve-se, entretanto, dispensar a caução nas hipóteses em que a parte é economicamente hipossuficiente, não podendo oferecê-la (art. 300, $\S 1^{\circ}$, in fine, CPC). Sobre o assunto, há o entendimento consolidado no enunciado 497 do FPPC, segundo o qual: “As hipóteses de exigência de caução para a concessão de tutela provisória de urgência devem ser definidas à luz do art. 520, IV, CPC. " 67

De toda a sorte, de acordo com o artigo 302 do CPC a parte que requereu a tutela provisória de urgência, independentemente da reparação por dano processual, responderá pelo prejuízo que a efetivação da tutela de urgência causar à parte adversa, se: I - a sentença lhe for desfavorável; II - obtida liminarmente a tutela em caráter antecedente, não fornecer os meios necessários para a citação do requerido no prazo de 5 (cinco) dias; III - ocorrer a cessação da eficácia da medida em qualquer hipótese legal; IV - o juiz acolher a alegação de decadência ou prescrição da pretensão do autor.

\footnotetext{
${ }^{66}$ Art. 300. A tutela de urgência será concedida quando houver elementos que evidenciem a probabilidade do direito e o perigo de dano ou o risco ao resultado útil do processo. $\S 1$ 욱a a concessão da tutela de urgência, o juiz pode, conforme o caso, exigir caução real ou fidejussória idônea para ressarcir os danos que a outra parte possa vir a sofrer, podendo a caução ser dispensada se a parte economicamente hipossuficiente não puder oferecê-la.

${ }^{67}$ ENCONTRO DO FÓRUM PERMANENTE DE PROCESSUALISTAS CIVIS, 7., 2016, São Paulo. Enunciados do Fórum Permanente de Processualistas Civis. Disponível em: <http: //www.cpcnovo.com.br/wp-content/uploads/2016/06/FPPC-Carta-de-Sa\%CC\%83o-Paulo.pdf>. Acesso em: 16 abr. 2018.
} 
Decerto, a tutela provisória de urgência pode ser deferida antes da oitiva da parte contrária (inaudita altera parte), liminarmente ${ }^{68}$ ou após a realização de uma audiência de justificação prévia na qual se permita ao demandante a produção da prova oral destinada a demonstrar a presença dos requisitos autorizadores de sua concessão (artigo 300, $§ 2^{\circ}$, do Código de 2015).

De acordo com Fredie Didier, Paula Braga e Rafael Oliveira (2016, p. 591593) o requerimento em caráter antecedente é sempre liminar, enquanto o realizado em caráter incidental pode se dar de forma liminar ou em outro momento do processo. Em todo o caso, a concessão da medida independe do momento em que for requerida pela parte, de modo que poderá o magistrado, sempre que entender inexistir risco de dano, não realizar a análise liminar e aguardar o contraditório para tomar uma decisão.

Vale dizer, por fim, que a avaliação da oportunidade da concessão liminar da tutela de urgência, antecedente ou incidente, deve permanecer condicionada a um juízo positivo firme da existência do direito do requerente e da inevitabilidade do dano iminente, assim como a um juízo de ponderação favorável à prioridade da tutela do direito alegado pelo requerente sobre o eventual direito do requerido que será sacrificado, e sobre o direito ao contraditório e à ampla defesa, cuja postergação constituirá, sempre, uma violência. ${ }^{69}$

\section{2 .2}

\section{Tutela provisória de evidência}

Com efeito, nas lições de Fred Didier, Paula Braga e Rafael Oliveira (2016, p. 630) a evidência é um fato jurídico processual; um estado processual em que as afirmações de fato estão comprovadas. Trata-se, de um "fato jurídico processual

\footnotetext{
68 "Decisão liminar deve ser entendida como aquela concedida in limine litis, isto é, no início do processo, sem que tenha havido ainda a citação ou a oitiva da parte contrária. Assim, tem-se por liminar um conceito tipicamente cronológico, caracterizado apenas por sua ocorrência em determinada fase do procedimento: o seu início. Liminar não é substantivo. Liminar é a qualidade daquilo que foi feito no início (in limine). Adjetivo, pois.”. (DIDIER JR., Fredie; BRAGA, Paula Sarno; OLIVEIRA, Rafael Alexandria de. Curso de direito processual civil. 11. ed. Salvador: Juspodivm, 2016, v. 2. p. 592).

${ }^{69}$ GRECO, Leonardo. A tutela da urgência e a tutela da evidência no código de processo civil de 2015. In: DIDIER JR., Fredie; FREIRE, Alexandre; MACÊDO, Lucas Buril de; PEIXOTO, Ravi (Orgs.). Procedimentos especiais, tutela provisória e direito transitório. Coleção Novo CPC. Doutrina Selecionada. 2. ed. Salvador: Juspodivm, 2016, v. 4. p. 199.
} 
que autoriza que se conceda uma tutela jurisdicional, mediante técnica de tutela diferenciada.".

Em outros termos, denomina-se tutela da evidência uma medida destinada a antecipar o próprio resultado prático final do processo, satisfazendo-se, na prática, o direito do demandante, independentemente da demonstração de perigo de dano ou de risco ao resultado útil do processo (art. 311 do CPC).

A tutela provisória da evidência permite ao juiz que antecipe uma medida satisfativa, transferindo para o réu os ônus da demora. Trata-se, em verdade, de uma tutela antecipada não urgente, pois se destina a antecipar o resultado prático final do processo, satisfazendo o direito do demandante, independentemente da existência do periculum in mora.

Destarte, a tutela de evidência é sempre deferida em cognição sumária e em caráter provisório. Portanto, precisará ser substituída pelo provimento definitivo, de modo que nas quatro hipóteses previstas nos incisos do artigo 311 do CPC há possibilidade de que a decisão respectiva seja revogada.

Outrossim, é sempre incidental ao processo em que se tenha formulado o pedido de tutela final, sendo que, nos casos previstos nos incisos I e IV, do art. 311, do CPC somente poderá ser deferida após o oferecimento da contestação, malgrado a lei processual permita que a tutela de evidência seja deferida inaudita altera parte nos casos previstos nos incisos II e III, do art. 311, por força da redação dos artigos 9, parágrafo único, II e 311, parágrafo único, todos do CPC/2015.

Nesse aspecto, passemos a analisar o rol de hipóteses previstas pelos incisos I a IV, do artigo 311 do CPC, que autorizam a concessão da tutela da evidência. São elas: I - ficar caracterizado o abuso do direito de defesa ou o manifesto propósito protelatório da parte; II - as alegações de fato puderem ser comprovadas apenas documentalmente e houver tese firmada em julgamento de casos repetitivos ou em súmula vinculante; III - se tratar de pedido reipersecutório fundado em prova documental adequada do contrato de depósito, caso em que será decretada a ordem de entrega do objeto custodiado, sob cominação de multa; IV - a petição inicial for instruída com prova documental suficiente dos fatos constitutivos do direito do autor, a que o réu não oponha prova capaz de gerar dúvida razoável.

O inciso I, do art. 311, do CPC traz a previsão de uma tutela intitulada por Fred Didier como "tutela de evidência punitiva”, eis que tem por objetivo sancionar aquele que exerce seu direito de defesa de forma abusiva, impondo empecilhos e 
protelando o regular andamento do feito. (DIDIER JR.; BRAGA; OLIVEIRA, 2016, p. 633). Esta tutela pode ser concedida em situações como: reiterada retenção dos autos por tempo prolongado; fornecimento de endereços incorretos para prejudicar as intimações e citações; prestar informações erradas; atrapalhar a produção de provas; invocar uma teratológica ou oposta a orientação dominante dos tribunais; alienação de bens necessários à satisfação da pretensão do demandante; repetir requerimentos já indeferidos etc.

Note-se que a doutrina distingue as expressões "abuso de direito de defesa" de "manifesto propósito protelatório", afirmando que a primeira possui uma interpretação mais ampla, abarcando os abusos e excessos cometidos em qualquer manifestação da parte, em defesa, e praticados dentro do processo; enquanto o manifesto propósito protelatório, se refere aos comportamentos da parte, protelatórios, adotados fora do processo, a exemplo da simulação de doença, ocultação de provas, etc. (DIDIER JR.; BRAGA; OLIVEIRA, 2016, p. 634).

Outra hipótese de tutela de evidência é a prevista no inciso II, do artigo 311, do CPC, que permite sua concessão quando "as alegações de fato puderem ser comprovadas apenas documentalmente e houver tese firmada em julgamento de casos repetitivos ou em súmula vinculante.”.

Como se vê, nesse caso, a concessão da tutela de evidência está condicionada a satisfação de dois requisitos: existência de prova das alegações de fato da parte requerente e existência de tese firmada em precedente ou súmula vinculante.

Em um primeiro momento, exige-se que a prova documental trazida com a inicial seja suficiente para demonstrar a veracidade de todas as alegações deduzidas, frisando que para a doutrina (DIDIER JR.; BRAGA; OLIVEIRA, 2016, p. 637), essa prova, necessariamente, deve ser a documental ou documentada (a exemplo da prova emprestada ou produzida antecipadamente), e, ainda, recair sobre fatos que justifiquem o nascimento do direito pretendido.

Além disso, exige-se, também, a existência de precedente ou súmula vinculante aplicável ao caso concreto, isto é, na probabilidade do acolhimento da pretensão processual, notadamente porque o fundamento da demanda se consubstancia em tese jurídica firmada em precedente obrigatório, que vincula o julgador, devendo ser observado.

A terceira hipótese de concessão de tutela da evidência está disciplinada pelo inciso III, do art. 311, do CPC. Consiste em permitir a tutela provisória com base 
no contrato de depósito. Trata-se de hipótese que veio assumir o lugar do procedimento especial de depósito previsto no direito anterior.

De acordo com a lei processual será deferida a tutela de evidência quando o demandante postular a restituição da coisa depositada, fundando seu pedido em "prova documental adequada do contrato de depósito", lembrando que nos casos de demanda fundada em contrato de depósito voluntário ou de depósito necessário legal, essa prova será a escrita, enquanto a demanda que se consubstancie em depósito miserável é demonstrável por qualquer prova documental, ainda que não escrita, a exemplo de fotografias e vídeos. ${ }^{70}$

Portanto, uma vez existindo prova suficiente do contrato de depósito, o demandante poderá ser prestigiado com a tutela provisória da evidência, cabendo ao magistrado proferir decisão determinando a entrega da coisa, sob pena de aplicação de multa.

Por último, a hipótese do inciso IV, admite a concessão da tutela provisória de evidência quando "a petição inicial for instruída com prova documental suficiente dos fatos constitutivos do direito do autor, a que o réu não oponha prova capaz de gerir dúvida razoável.”.

Com efeito, para a aplicação da tutela provisória com base nesse inciso, fazse necessária a observância de 03 (três) pressupostos.

O primeiro está relacionado ao fato de que a evidência deva ser demonstrada pelo autor e que não seja rechaçada pelo réu mediante prova exclusivamente documental. Logo, a causa deve versar sobre questão a ser comprovada basicamente por prova documental.

O segundo requisito se refere à necessidade de que o autor produza prova documental (ou documentada) suficiente dos fatos constitutivos do direito invocado,

Quanto ao terceiro, que inexista prova produzida pelo réu que seja apta a gerar dúvida razoável em torno do fato constitutivo do direito do autor ou do próprio direito do autor.

\footnotetext{
${ }^{70}$ Sobre o assunto, Alexandre Câmara relembra que: “(...) o depósito voluntário só se prova por escrito (art. $646 \mathrm{CC}$ ), regra também aplicável ao contrato de depósito necessário legal (arts. 647, I e 648 do CC). O depósito miserável (art. 647, II, do CC) é demonstrável por qualquer meio de prova (art. 648, parágrafo único, do CC).”. (CÂMARA, Alexandre Freitas. O novo processo civil brasileiro. 2. ed. São Paulo: Atlas, 2016. Disponível em: < http://www.academia.edu/32073955/C\%C3\%82MARA_Alexandre_Freitas._O_Novo_Processo_C ivil_Brasileiro._2._ed>. Acesso em: 10 abr. 2018).
} 
Por tudo isso, percebe-se que a tutela de evidência se caracteriza por antecipar os efeitos da tutela pretendida, contudo dispensa a urgência. Isso é o que se extrai do mencionado artigo 311 do CPC.

Entrementes, o requisito para concessão da tutela da evidência é a evidência do direito, o que, certamente, conduz a conclusão de que a tutela é medida cabível quando a procedência dos pedidos for praticamente certa. Nesse sentido, Leonardo Ferres da Silva Ribeiro aduz que:

Na tentativa de definir a tutela de evidência, surge, como primeira indagação, o que seria um direito evidente? Para Luiz Fux, no plano processual, direito evidente seria aquele 'cuja prova dos fatos sobre os quais incide revela-os incontestáveis ou ao menos impossíveis de contestação séria'. Por sua vez, para Rui Cunha Martins, evidente é o que dispensa prova. ${ }^{71}$

Desta feita, estabelecendo as diferenças entre as tutelas provisórias de urgência e da evidência Marinoni, Arenhart e Mitidiero afirmam que:

A técnica antecipatória - que é capaz de dar lugar às "tutelas provisórias" do legislador - tem justamente por função distribuir de forma isonômica o ônus do tempo no processo. Para tanto, fundamenta-se ora na urgência, ora na evidência do direito postulado em juízo (é por essa razão que o legislador refere que "a tutela provisória pode fundamentar-se em urgência ou evidência. Art. 294). A "tutela provisória de urgência" pode ser "cautelar ou antecipada" (isto é, satisfativa, art. 294, parágrafo único), ao passo que a tutela da evidência é sempre satisfativa (art. 311). ${ }^{72}$

Ademais, Didier Jr., Braga e Oliveira (2016, p. 417-418) estabelecem as diferenças entre a tutela de urgência e de evidência dizendo que enquanto a primeira requer a demonstração de uma probabilidade do direito e um perigo de dano ou risco ao resultado útil do processo, a segunda exige a demonstração das alegações e, além disso, a sua comprovação, tornando evidente o direito.

Por outro norte, não há dúvidas em se afirmar que apesar da tutela de evidência conduzir a uma certeza quase absoluta do direito invocado pelo autor, permanece com sua natureza provisória, razão pela qual não pode ser confundida com o julgamento antecipado da lide.

Em suma, a tutela de evidência possui como pressuposto a evidência do direito, sendo mais do que apenas a fumaça do bom direito, até porque dispensa

\footnotetext{
${ }^{71}$ RIBEIRO, Leonardo Ferres da Silva. Tutela provisória: tutela de urgência e tutela da evidência - do CPC/1973 ao CPC/2015. São Paulo: RT, 2015. p. 90.

72 MARINONI, Luiz Guilherme; ARENHART, Sérgio Cruz; MITIDIERO, Daniel. Novo curso de processo civil: tutela dos direitos mediante procedimento comum. São Paulo: RT, 2015, v. 2. p. 198.
} 
outro requisito característico das tutelas diferenciadas que é a urgência. Todavia, não é demais lembrar que, em se encaixando o caso concreto em algumas das hipóteses previstas no rol do art. 311, do CPC, nada impede, uma vez preenchidos os requisitos, que a parte se utilize da técnica antecipatória.

\section{3 \\ Natureza da tutela provisória de urgência: cautelar ou antecipada}

O ilustre Teori Zavascki (2008, p. 26) delimitava a tutela provisória como sendo uma tutela diferenciada, que outorga providências de dois tipos: "(a) providências antecipadoras do gozo do direito vindicado e (b) providências de garantia para a futura execução.".

Dessa delimitação, portanto, percebe-se que a tutela provisória de urgência pode ser satisfativa ou cautelar.

Com efeito, parte da doutrina concebe a cautelar como uma auxiliar da jurisdição, no sentido de que é um instrumento de proteção processual contra o tempo. Nessa linha, inclusive, a parte final do artigo 300 do CPC prevê a possibilidade de concessão da tutela de urgência quando houver elementos que evidenciem "risco ao resultado útil do processo".

Não há um posicionamento unânime frente a doutrina. Mas, esse trabalho adota a tese de Marinoni, Arenhart e Mitiero (2015, p. 198), que firmam entendimento no sentido de que a tutela cautelar não é uma tutela ao processo, mas sim ao direito da parte. Logo, para esses doutrinadores, a cautelar não assegura apenas a efetiva prestação jurisdicional ou o bom funcionamento do judiciário, mas, sobretudo, almeja proteger um direito ou uma situação jurídica tutelável pelo processo principal.

Nesse prisma, a tutela provisória cautelar antecipa os efeitos de tutela definitiva não satisfativa (cautelar), conferindo eficácia imediata ao direito à cautela, isto é, há a antecipação da cautela a determinado direito. Por conseguinte, como ressaltado por Fred Didier Júnior, Paula Braga e Rafael Oliveira (2016, p. 583), essa tutela somente se justifica diante de uma situação de urgência do direito a ser acautelado, que exija sua imediata preservação, de forma a garantir sua futura satisfação. 
Não é por outra razão que a tutela provisória cautelar possui dupla função: é provisória, sobretudo por dar eficácia imediata à tutela definitiva não satisfativa; e é cautelar, justamente por assegurar a futura eficácia da tutela definitiva satisfativa, resguardando o direito a ser satisfeito.

Nesse aspecto, as medidas cautelares são deferidas com base no poder geral de cautela do juiz, de modo que, diferentemente do antigo regime adotado pelo direito brasileiro desde suas origens lusitanas, não há no CPC/2015 a previsão de medidas cautelares específicas, mas, apenas, do poder genericamente atribuído ao magistrado de deferir as medidas cautelares.

Essa é a conclusão que se extrai do artigo 301, do CPC, segundo o qual: "A tutela de urgência de natureza cautelar pode ser efetivada mediante arresto, sequestro, arrolamento de bens, registro de protesto contra alienação de bem e qualquer outra medida idônea para asseguração do direito.”. Logo, percebe-se que a enumeração das medidas cautelares ali disposta é meramente exemplificativa, o que não afasta a assertiva no sentido de que "o poder geral de cautela está mantido no CPC." $" 73$.

Por sua vez, a tutela provisória satisfativa - ou, simplesmente, "tutela antecipada", terminologia essa utilizada pelo legislador - antecipa os efeitos da tutela definitiva satisfativa, de modo a assegurar eficácia imediata ao direito reivindicado. Nesse caso, há o adiantamento da satisfação do direto, antecipando, assim, aquilo que foi requerido pelo interessado.

A toda a evidência, se a tutela antecipada fosse total e ostentasse caráter definitivo, e não provisório, o autor ficaria plenamente satisfeito. Mas, dada a sua natureza provisória, ela precisa ser substituída por um provimento definitivo. Por isso, a efetivação da tutela antecipada observará as normas referentes ao cumprimento provisório de sentença, no que couber (CPC, art. 297, parágrafo único, $\mathrm{CPC})$.

Desta feita, vê-se que existe direito à satisfação dos direitos e existe direito à sua asseguração. E, por assim ser, a técnica processual tanto pode levar à prestação da tutela satisfativa como a prestação da tutela cautelar.

\footnotetext{
${ }^{73}$ Nesse sentido, o enunciado 31 do FPPC: “O poder geral de cautela está mantido no CPC.”.
} 
Destarte, esse é o sentido a que se refere o legislador quando no artigo 294, parágrafo único, do CPC/2015 estabeleceu que a tutela provisória de urgência pode ser satisfativa (antecipada) ou cautelar.

Entrementes, a tutela cautelar se distingue da tutela satisfativa não apenas por terem objetos distintos (a saber: asseguração e certificação/efetivação, respectivamente), mas, em especial, porque a tutela cautelar é dotada de características próprias, que para Didier Jr., Braga e Oliveira seriam a temporariedade e a referibilidade. (2016, p. 576).

A despeito da referibilidade a tutela cautelar se configura, necessariamente, como uma tutela que se refere a outro direito, que, nessa condição, se difere do direito à cautela. Por conseguinte, há uma distinção entre o direito à cautela com o direito que se acautela, isto é: "o direito à cautela é o direito à tutela cautelar; o direito que se acautela, ou direito acautelado, é o direito sobre que recai a tutela cautelar.”. (DIDIER JR.; BRAGA; OLIVEIRA, 2016, p. 576).

A tutela cautelar é temporária, mormente porque sua eficácia é limitada no tempo, de modo a perdurar pelo prazo necessário a preservação daquilo que se propôs. Outrossim, perde essa eficácia quando cumprida sua função acautelatória, lembrando que tende a extinguir-se com a obtenção da tutela satisfativa definitiva, a se materializar com a resolução da demanda principal na qual se discute e/ou se efetiva o direito acautelado.

Essa é a visão de Fred Didier, Paula Braga e Rafael Oliveira (2016, p. 577), que encontra resistência através de um posicionamento peculiar. Daniel Mitidiero sustenta que toda a tutela, seja ela cautelar ou satisfativa, tem eficácia temporária. Entretanto, no seu entendimento, para que seus efeitos cessem é necessário que ocorra uma mudança da situação fática-jurídica que ensejou sua concessão, de modo que para esse especialista, o que há de peculiar na tutela cautelar é que a situação fático-jurídica que lhe serve de base é naturalmente mais instável, o que torna mais evidente a sua "temporariedade eficacial". ${ }^{74}$

Por outro norte, Ovídio A. Baptista deixa claro que a temporariedade na tutela cautelar decorre das características dos efeitos por ela emanados, que podem ser removidos quando desaparecer a necessidade de proteção cautelar. Além disso, os

\footnotetext{
${ }^{74}$ MITIDIERO, Daniel Francisco. Tendências em matéria de tutela sumária: da tutela cautelar à técnica antecipatória. Revista de Processo. vol. 197, p. 27-65. São Paulo: RT, Jul/2011. p.35.
} 
efeitos que perdurarem enquanto houver necessidade de cautela, deverão ser removidos - e não substituídos - caso desapareça a situação perigosa. ${ }^{75}$

Destarte, com base em reflexões desse doutrinador, Fred Didier Júnior, Paula Braga e Rafael Oliveira (2016, p. 577) fazem uma distinção entre o provisório e o temporário, concebendo-se o provisório com a possibilidade de sempre ser preordenado a ser substituído pelo definitivo que goza da mesma natureza. Nesse prisma, utilizam como exemplo um "flat" provisório utilizado por um casal até ser substituído pela habitação definitiva (apartamento de edifício em construção).

Outrossim, “o temporário é definitivo, nada virá em seu lugar (de mesma natureza)" (DIDIER JR.; BRAGA; OLIVEIRA, 2016, p. 577), malgrado seus efeitos sejam limitados no tempo, e predispostos à cessação. Nesse caso, exemplificam a situação com os andaimes colocados para a pintura do edifício em que o casal irá residir, que lá permanecerão pelo tempo necessário para conclusão do serviço (e feito o serviço, de lá sairão, mas nada os substituirá).

Em consequência, para esses juristas, a decisão que concedeu a medida permanece inalterada em seu dispositivo, não sendo substituída por outra de mesma natureza. Já provisória seria a tutela na qual seus efeitos são passíveis de modificação.

Em sendo assim, pelo menos, em princípio, a tutela cautelar em muito se difere da tutela antecipada. No entanto, em alguns casos práticos pode não ficar tão clara essa diferença.

Destarte, Leonardo Ferres da Silva Ribeiro comentando sobre possíveis problemas na escolha entre cautelar ou antecipada, simplifica:

Tome-se, como exemplo, a sustação de protesto que, se de um lado apresenta nítido caráter acautelatório, de outro, parece antecipar um dos efeitos que adviria com a fruição da tutela buscada a final. Há, nesses casos, uma evidente zona de fronteira entre tais funções - conservativa e antecipatória - no âmbito das tutelas de urgência, porém isso não quer significar que sejam coisas distintas. Não são. Ambas são tutelas de urgência, cada qual desempenhando uma função predominante. (RIBEIRO, 2015, p. 88).

De toda a sorte, pode-se afirmar que tanto a tutela cautelar quanto a tutela antecipada são tutelas de urgência, cada qual desempenhando uma função predominante.

\footnotetext{
${ }^{75}$ SILVA, Ovídio A. Baptista da. Do processo cautelar. 3. ed. Rio de Janeiro: Forense, 2006. p. 86.
} 
Além disso, na prática, a alteração dada pelo CPC/15 em nada modificou os efeitos da tutela cautelar, que continuará tendo como característica a temporariedade, frisando, por derradeiro, que a previsão dada pelo art. $296^{76}$ do CPC/15 não difere em seu sentido da previsão do art. $807^{77}$ do $\mathrm{CPC} / 73$.

\section{4}

\section{Forma de requerimento da tutela provisória: incidental ou antecedente}

Como se sabe, essa classificação leva em consideração o momento em que o pedido de tutela provisória é formulado, em comparação com o momento em que se formula o pedido da tutela definitiva. Por isso, podendo ser requerida antes ou conjuntamente a esse pedido.

A tutela de urgência pode ser requerida em caráter antecedente ou incidental, diferentemente da tutela provisória de evidência, que só pode ser requerida em caráter incidente.

Com efeito, a tutela provisória incidental é aquela formulada nos próprios autos do processo em que se requer ou já se requereu a tutela definitiva, tendo por objetivo, assim, adiantar seus efeitos (satisfação ou acautelamento), independentemente do pagamento de custas (art. 295, CPC). ${ }^{78}$

O pedido incidental pode ser formulado na petição inicial (contestação, petição de ingresso do terceiro ou de manifestação do Ministério Público); petição simples; oralmente, em mesa de audiência ou durante a sessão de julgamento no Tribunal; ou no bojo da petição recursal. Ademais disso, não há necessidade de pagamento de custas, por força do que dispõe o art. 295, do CPC.

É claro, porém, que quando a tutela provisória for requerida incidentalmente, o juízo competente para examinar o requerimento será aquele onde tramita o feito, sobretudo porque em se tratando de um requerimento incidental, poderá ser deduzido a qualquer tempo, não se submetendo a preclusão temporal, tal como consta do enunciado 496 do FPPC, in verbis:

\footnotetext{
${ }^{76}$ Art. 296. A tutela provisória conserva sua eficácia na pendência do processo, mas pode, a qualquer tempo, ser revogada ou modificada.

77 Art. 807. As medidas cautelares conservam a sua eficácia no prazo do artigo antecedente e na pendência do processo principal; mas podem, a qualquer tempo, ser revogadas ou modificadas.

${ }^{78}$ Art. 295. A tutela provisória requerida em caráter incidental independe do pagamento de custas.
} 
Preenchidos os pressupostos de lei, o requerimento de tutela provisória incidental pode ser formulado a qualquer tempo, não se submetendo à preclusão temporal.

Vale ressaltar que de acordo com o art. $300, \S 2^{\circ}$, do CPC, "a tutela de urgência pode ser concedida liminarmente ou após justificação prévia.”. A regra geral, no entanto, é proceder-se a ouvida prévia da outra parte, em observância aos postulados constitucionais do contraditório e da ampla defesa, na forma do art. $5^{\circ}, \mathrm{LV}$, da Carta Magna. Mas, nada impede a concessão da liminar inaudita altera parte, notadamente quando o risco de dano for imediato.

De toda sorte, é importante destacar que o pedido de tutela de urgência será formulado com observância dos requisitos previstos no art. 300 do CPC, devendo, pois, ser devidamente instruída com a prova adequada de suas alegações.

Por sua vez, no que tange a tutela provisória antecedente, objeto do próximo capítulo a ser abordado por esse trabalho, convém apenas adiantar que é o instituto concebido como aquele que deflagra o processo em que se pretende no futuro, requerer a tutela definitiva.

Apresenta-se como um requerimento anterior à formulação do pedido de tutela definitiva, tendo por objetivo adiantar seus efeitos, a saber: satisfação ou acautelamento.

Destarte, o pedido antecedente possui procedimento próprio e diferente para cada modalidade de tutela de urgência, atribuindo-se um procedimento distinto ao pedido de tutela antecipada antecedente e tutela cautelar antecedente, conforme se observará no tópico a seguir. 


\section{A tutela requerida em caráter antecedente}

\section{1}

\section{Conceito de tutela antecedente}

Nas lições de Fredie Didier Jr., Paula Sarno Braga e Rafael Alexandria de Oliveira (2016, p. 586), a tutela provisória antecedente é aquela em que se deflagra o processo no qual se pretende, no futuro, requerer a tutela definitiva. Ou seja, considera-se antecedente toda a medida urgente que é pleiteada antes da dedução em juízo do pedido principal, seja ela de natureza cautelar ou satisfativa.

Com efeito, trata-se de um requerimento anterior à formulação do pedido de tutela definitiva e tem por objetivo adiantar seus efeitos (satisfação ou acautelamento).

Decerto, a tutela provisória antecedente foi concebida para os casos em que a situação de urgência se encontre presente no momento da propositura da ação, razão essa que faz com que a parte não disponha de tempo hábil para reunir os elementos necessários para formular o pedido de tutela definitiva de modo satisfatório e completo, reservando-se a fazê-lo posteriormente.

Sucede que, malgrado as medidas cautelares e as satisfativas tenham sido integradas ao gênero comum da tutela de urgência, o novo Código faz uma distinção entre as medidas antecedentes cautelares e medidas antecedentes satisfativas, que são tuteladas por disposições procedimentais diferenciadas.

Assim é que o CPC/2015 prevê, expressamente, 02 (dois) procedimentos preparatórios de tutela provisória de urgência: o da tutela cautelar requerida em caráter antecedente, prevista nos arts. 305 a 310; e o da tutela antecipada requerida em caráter antecedente, disciplinada nos arts. 303 e 304.

Decerto, tratam-se de institutos que possuem semelhanças, mormente se considerado que pertencem ao mesmo gênero "tutela provisória" e são dotados de procedimentos igualmente antecedentes.

No entanto, a regulamentação desses institutos se distingue, primeiramente porque a natureza das tutelas é diferente - a "antecipada" é satisfativa do pedido, enquanto a cautelar não o satisfaz, sendo meramente assessória, destinada a garantir 
a efetividade de outra espécie de tutela jurisdicional; e em segundo, pelo fato do requerimento da cautelar antecedente exigir a formulação do pedido (satisfativo) principal no prazo de 30 dias (art. 308), enquanto o requerimento de tutela antecipada antecedente pode dispensar a formulação do pedido principal em determinada hipótese (art. 304). ${ }^{79}$

Logo, passa-se a discorrer sobre essas diferenças, notadamente no que se refere aos procedimentos próprios de cada instituto.

\section{2 \\ Procedimento da tutela de urgência satisfativa (antecipada) requerida em caráter antecedente}

Como se sabe, o art. 303 do CPC regula o procedimento da tutela antecipada requerida em caráter antecedente. Trata-se de uma inovação trazida pelo Novo Código, não prevista no $\mathrm{CPC} / 73$, uma vez que, por esse ordenamento, o pleito de antecipação dos efeitos da tutela jurisdicional era formulado na petição inicial, juntamente com o pedido principal, ou incidentalmente.

Decerto, o procedimento previsto pela sobredita regra normativa é destinado, especificamente, a proporcionar a estabilização da medida provisória satisfativa prevista pelo art. 304 do CPC, especialmente por basear-se na existência de elementos concretos que permitam ao magistrado o deferimento do requerimento, sem a necessidade de formulação do pedido de tutela final de maneira completa.

Em consequência disso, a doutrina entende que seria uma modalidade de sumarização procedimental para efetivar a tutela materialmente sumária, isto é, uma abreviação procedimental com a adoção de técnicas que tornam mais ágeis a prestação da tutela jurisdicional. ${ }^{80}$

Segundo a dicção do art. 303, CPC/2015, quando a urgência for contemporânea à propositura da ação, o requerente poderá, na petição inicial, limitar-se a requerer o pleito antecipatório e a indicar o pedido correspondente à

\footnotetext{
79 REDONDO, Bruno Garcia. Estabilização, modificação e negociação da tutela de urgência antecipada antecedente: principais controvérsias. Revista de Processo. v. 244, a. 40. São Paulo: RT, jun. 2015. p. 167-194.

${ }^{80}$ GODINHO, Robson Renault. Comentários aos artigos 294 a 311. In CABRAL, Antonio do Passo; CRAMER, Ronaldo (Coord). Comentários ao novo código de processo civil. 2. ed. Rio de Janeiro: Forense, 2016. p. 474-475.
} 
tutela final, com a exposição da lide, do direito que se busca realizar e do perigo de dano ou do risco ao resultado útil do processo.

Sobre a contemporaneidade da urgência com a propositura da ação, Robson Renault Godinho (2016, p. 474-475) afirma que a mesma está contida na “indicação do pedido final", mormente porque não seria razoável exigir que fosse compreendida como simultaneidade, até porque, a contrário senso, a autonomia procedimental do instituto se tornaria inútil.

Porquanto, vê-se que para a adoção do procedimento em questão, o autor ingressará em juízo limitando-se a deduzir o requerimento de tutela provisória satisfativa, procedendo-se, nessa oportunidade, a indicação do pedido de tutela final, que, como será visto, poderá ser formulado por emenda.

Outrossim, a inicial respectiva deverá estar acompanhada da exposição da lide, do direito que se busca realizar e do perigo de dano ou do risco ao resultado útil do processo (periculum in mora), sem prejuízo da indicação do juiz competente, das partes com suas qualificações, das provas que servirão de substrato a comprovação da verdade dos fatos alegados, bem como do valor da causa, que, consoante art. $303, \S 4^{\circ}$, do CPC, deverá levar em consideração o pedido de tutela final.

Nesse particular, nas lições de Leonardo Ferres da Silva Ribeiro (2015, p. 219), o pedido de tutela antecipada antecedente é medida excepcional, justificandose diante de uma urgência contemporânea à propositura da ação (art. 303), ou seja, a impossibilidade de, naquele determinado momento, dada uma situação de urgência, instruir adequadamente a ação que contemple o pedido final.

Com isso, quer-se dizer que a parte que se utilizar da antecipação da tutela por meio de pedido antecedente, deverá demonstrar uma urgência atual, a justificar, portanto, a dispensa dos requisitos da petição inicial, previstos pelos artigos 319 e 320 do CPC.

Por fim, a última exigência a ser observada pelo autor ao postular a tutela antecipada em caráter antecedente é a de informar ao magistrado de que pretende se valer do benefício previsto no caput, do art. 303, do CPC. ${ }^{81}$ Em outros termos é dever da parte informar ao juiz que o pedido deduzido se limita ao requerimento de

\footnotetext{
${ }^{81}$ Nesse sentido, o art. $303, \S 5^{\circ}$, do CPC: “§ 5을 $\mathrm{O}$ autor indicará na petição inicial, ainda, que pretende valer-se do benefício previsto no caput deste artigo.".
} 
antecipação da tutela, de sorte que, oportunamente, se utilizará do aditamento, para a apresentação de novos argumentos e documentos.

Com efeito, ultrapassada essa fase, e submetida a inicial à apreciação judicial, o juiz poderá conceder ou indeferir a tutela antecipada.

Não concedida a tutela antecipada, por entender o juiz que a petição inicial está incompleta, não apresentando os elementos que autorizam seu deferimento, caberá ao autor, sem prejuízo da possibilidade de interpor o recurso cabível (art. 1.015, I, CPC), proceder a emenda (rectis: aditar) da petição inicial, no prazo de 05 (cinco dias), adequando-a aos moldes do procedimento (art. 303, §6 $6^{\circ}, \mathrm{CPC}$ ).

Com relação a esse prazo de 05 (cinco dias), perceba-se que ele é mais reduzido do que aquele previsto no art. 321 do CPC, que assegura a emenda a inicial em 15 (quinze) dias. Por outro lado, há quem defenda que esse prazo previsto no art. $303, \S 6^{\circ}$ pode ser dilatado pelo juiz, com fulcro no art. 139 , VI, CPC. ${ }^{82}$

Em todo o caso, a emenda possui significante função no procedimento, pois revela-se necessária para que o autor complemente sua causa de pedir, ratifique seu pedido de tutela definitiva e forneça os documentos indispensáveis a propositura da futura demanda. Por isso, há entendimento doutrinário sustentando que seu alcance deverá ser o mais amplo possível, pois nessa fase processual ainda não houve a citação do réu. ${ }^{83}$

Daí é que, nesse mister poderá o autor modificar (ampliar ou reduzir) o requerimento de tutela antecipada; formular pedido de tutela da evidência (incisos II ou III do art. 311); modificar os elementos da demanda (partes, causa de pedir e o pedido de tutela final), por força do art. 329, do CPC; e, ainda, juntar novas provas que embasem seu pleito.

Por outro lado, em não se desincumbindo desse ônus, o autor arcará com indeferimento de sua petição inicial, e com a extinção do processo sem resolução do mérito. Mas, uma vez realizada, o procedimento prosseguirá, com a consequente solução sobre a medida requerida em caráter urgente.

\footnotetext{
${ }^{82}$ Adepto a essa dilação, REDONDO, Bruno Garcia. Estabilização, modificação e negociação da tutela de urgência antecipada antecedente: principais controvérsias. Revista de Processo. v. 244, a. 40. São Paulo: RT, jun. 2015. p. 167-194. Em sentido contrário, defendendo a impossibilidade de ampliação, pelo juiz, do prazo de 05 dias para emenda, NERY JR., Nelson; NERY, Rosa Maria de Andrade. Código de processo civil comentado e legislação extravagante. 11. ed. São Paulo: RT, 2010. p. 863.

${ }^{83}$ Nesse sentido: REDONDO, Bruno Garcia. Estabilização, modificação e negociação da tutela de urgência antecipada antecedente: principais controvérsias. Revista de Processo. v. 244, a. 40. São Paulo: RT, jun. 2015. p. 167-194.
} 
Entrementes, concedida a tutela provisória satisfativa (antecipada) antecedente, outras providências deverão ser adotadas pelo magistrado, como se extrai do art. $303, \S \S 1^{\circ}, 2^{\circ}$ e $3^{\circ}$, do CPC.

A primeira providência é determinar a intimação do autor para aditar a petição inicial, nos mesmos autos, com o intuito de complementar sua argumentação, juntar novos documentos, e, se for o caso, confirmar o pedido de tutela final, em 15 (quinze) dias ou em outro prazo maior que o juiz fixar. Ressalte-se que esse aditamento deverá se dar nos mesmos autos, não havendo a incidência de novas custas, por força da redação do art. $303, \S 3^{\circ}$, do CPC.

Outrossim, diverge a doutrina quanto a necessidade de que o autor se limite a confirmar em sua petição aditiva o pedido principal, ou se é possível a modificação ou ampliação do pedido deduzido no requerimento de tutela antecedente.

Para Teresa Arruda Alvim, Maria Lúcia Lins Conceição, Leonardo Ferres da Silva Ribeiro e Rogério Licastro Torres de Mello é vedado ao autor modificar (ampliar ou reduzir) o pleito que havia sido indicado na petição que requereu a tutela antecedente, por força da redação do inciso I, do $\S 1^{\circ}$, do art. 303 , do CPC, que estabelece: “o autor deverá aditar a petição inicial, com (...) a confirmação do pedido de tutela final (...).". 84

Todavia, há quem sustente que o pedido principal formulado na petição de aditamento pode ser mais amplo do que o indicado no requerimento da tutela em caráter antecedente, a exemplo de Jose Miguel Garcia Medina. ${ }^{85}$

É necessário que se observe que o aditamento da inicial é requisito de admissibilidade, ao passo que em não sendo realizado no prazo de quinze dias ou em outro prazo maior fixado pelo juiz, ensejará a extinção do processo sem a resolução do mérito, o que, inclusive, poderá afetar a tutela antecipada concedida, com a consequente cessação imediata da sua eficácia (art. 303, §2º.

Visto isso, a segunda providência está relacionada ao estabelecimento do postulado constitucional do contraditório, exigindo-se a citação e intimação do réu para ciência do conteúdo da providência deferida a título de tutela antecipada, e,

\footnotetext{
${ }^{84}$ WAMBIER, Teresa Arruda Alvim; CONCEIÇÃO, Maria Lúcia Lins; RIBEIRO, Leonardo Ferres da Silva; MELLO, Rogério Licastro Torres de. Primeiros comentários ao novo código de processo civil: artigo por artigo. São Paulo: RT, 2015. p. 508.

${ }^{85}$ MEDINA, José Miguel Garcia. Novo código de processo civil comentado: com remissões e notas comparativas ao CPC/73. 3. ed. São Paulo: RT, 2015. p.486-487.
} 
também, para que compareça a audiência de conciliação ou mediação prevista no art. 334, do CPC. Não havendo composição, o art. 303, $\S 1^{\circ}$, III, CPC determina que o prazo para a contestação deverá ser contado nos termos do art. 335, do CPC.

Nesse aspecto, é oportuno enfatizar que a doutrina apresenta questionamentos quanto ao prazo de resposta para o réu se insurgir contra a decisão que contemplou o pedido de tutela antecipada.

Para Fred Didier Junior, Paula Braga e Rafael Oliveira (2016, p. 616), para que se garanta um lapso temporal mínimo de quinze dias para a elaboração de uma resposta satisfatória ao requerimento formulado pelo autor, o prazo de resposta do réu não poderá começar a ser contado antes da ciência inequívoca do réu quanto ao aditamento da petição inicial do autor. Logo, para eles, se a causa não admitir autocomposição, e, portanto, não sendo cabível a designação de audiência de conciliação ou de mediação, o réu será citado de imediato, malgrado o prazo de resposta só se inicie a partir da data em que foi intimado do aditamento da petição inicial.

Na mesma linha, Robson Renault Godinho, assevera que:

(...) Desde logo, porém pode o réu manifestar-se nos autos para, se for o caso, insurgir-se contra a medida liminar, a fim de que seja modificada ou revogada, sem prejuízo da interposição de recurso de agravo de instrumento (art. 1.015, I, CPC), não devendo ser aguardado o resultado da tentativa de autocomposição e muito menos o previsto no art. 335 do CPC, a fim de não lhe ser causado prejuízo indevido. (GODINHO, 2016, p. 476).

Na hipótese do réu responder a demanda do autor ou recorrer da decisão que concedeu a tutela antecipada, será dada sequência ao procedimento comum, rumo as etapas de saneamento, instrução e decisão.

Entretanto, caso o réu não apresente impugnação contra a decisão inaudita altera parte, a tutela antecipada antecedente concedida integralmente torna-se estável e o processo é extinto (art. 304). Em suma, o procedimento segue outro rumo, com a possibilidade de estabilização da decisão, que, por versar sobre uma sistemática nova, sem correspondente no CPC/1973, será analisada com maiores detalhes no próximo capítulo, em especial no que tange as divergências que a envolvem. 


\section{3 Procedimento da tutela de urgência cautelar em caráter antecedente}

Para Fredie Didier Jr., Paula Sarno Braga e Rafael Alexandria de Oliveira (2016, p. 626), "a tutela provisória cautelar antecedente é aquela requerida dentro do mesmo processo em que se pretende, posteriormente, formular o pedido de tutela definitiva, cautelar e satisfativa.". Esta tem como principal objetivo, adiantar provisoriamente a eficácia da tutela definitiva cautelar, e assegurar a futura eficácia da tutela definitiva satisfativa.

O procedimento para o requerimento da tutela de urgência cautelar em caráter antecedente encontra previsão nos artigos 305 a 310 do Código de Processo Civil de 2015.

A despeito disso, a redação do art. 305 do CPC remete o seu leitor ao que no Código de Processo Civil de 1973 era intitulado de ação cautelar "preparatória". Sobre a questão, a crítica de Robson Renault Godinho no sentido de que o art. 305, CPC manteve o equívoco do CPC/1973 de tratar a tutela jurisdicional cautelar como um apêndice de um processo "principal", de modo que a autonomia da tutela cautelar permanece apenas procedimental. (GODINHO, 2016, p. 481).

Com efeito, o referido dispositivo legal indica os requisitos que deverão ser observados na petição inicial, quais sejam: os requisitos específicos elencados no artigo 319, incisos I, II, V e VI, do CPC; a indicação da lide e seu fundamento; a exposição sumária do direito que se objetiva assegurar; e o perigo de dano ou o risco ao resultado útil do processo. ${ }^{86}$

Decerto, uma vez verificando a satisfação dos requisitos da inicial, em sede de juízo de admissibilidade poderá o magistrado determinar a emenda da inicial (art. 321, CPC); indeferi-la (art. 330, CPC); ou deferi-la, se convencido de que se apresenta regular e em termos.

Desta feita, em sendo deferida, caberá ao magistrado proceder ao julgamento do requerimento liminar da tutela cautelar, se assim formulado, ou mediante

\footnotetext{
${ }^{86}$ De acordo com o art. 319, do CPC: “A petição inicial indicará: I - o juízo a que é dirigida; II - os nomes, os prenomes, o estado civil, a existência de união estável, a profissão, o número de inscrição no Cadastro de Pessoas Físicas ou no Cadastro Nacional da Pessoa Jurídica, o endereço eletrônico, o domicílio e a residência do autor e do réu; III - o fato e os fundamentos jurídicos do pedido; IV o pedido com as suas especificações; V - o valor da causa; VI - as provas com que o autor pretende demonstrar a verdade dos fatos alegados; VII - a opção do autor pela realização ou não de audiência de conciliação ou de mediação.”.
} 
justificação prévia, acaso necessária; determinar o cumprimento da medida; e, ainda, ordenar a citação do réu para, se assim o desejar, contestar o pedido e especificar as provas que pretende produzir, no prazo de 05 (cinco) dias, na forma do art. 306, do CPC.

Por outro lado, não contestado o pedido de tutela cautelar antecedente, os fatos alegados pelo autor presumir-se-ão aceitos pelo réu como ocorridos, de forma que o juiz proferirá decisão sobre ele no prazo de 05 (cinco) dias, a teor do art. 307, caput, do CPC. Note-se que a presunção de veracidade da revelia aqui tratada seguirá o regime jurídico geral, de que cuida o art. 344, do CPC.

Se contestado o pedido no prazo, estabelece o parágrafo único do art. 307 , do CPC, que o juiz prosseguirá pelo procedimento comum, frisando que consoante o Enunciado n. 381 do FPPC, "é cabível réplica no procedimento de tutela cautelar requerida em caráter antecedente.”.

Por sua vez, na hipótese de concessão da tutela de urgência cautelar em caráter antecedente, a tutela provisória cautelar deve ser efetivada no prazo de 30 (trinta) dias, sob pena de não mais poder sê-lo, eis que por força do artigo 309, II, do CPC, haverá a cessação da eficácia da tutela concedida.

Assim é que, efetivada a tutela cautelar (art. 309, II, CPC), com o emprego de qualquer das medidas adequadas para tanto (como, por exemplo, arresto, sequestro, arrolamento de bens e registro de protesto contra alienação de bens), o caput, do art. 308, do CPC exige que o pedido principal deva ser formulado pelo autor no prazo de 30 (trinta) dias, caso em que será apresentado nos mesmos autos em que formulado o requerimento de tutela cautelar, não dependendo do adiantamento de novas custas processuais.

Como bem sustentado por Leonardo Greco ${ }^{87}$, isso demonstra que o Novo CPC manteve a tradicional caracterização instrumental da tutela cautelar, precipuamente no que se refere à acessoriedade à ação principal.

Destarte, a tutela cautelar antecedente tem por objetivo antecipar a tutela definitiva cautelar, notadamente para assegurar a futura tutela satisfativa que se pretende nos mesmos autos.

\footnotetext{
${ }^{87}$ GRECO, Leonardo. A tutela de urgência e a tutela de evidência no código de processo civil de
} 2014/2015. Revista Eletrônica de Direito Processual. v. XIV, ano 8, jul.-dez. 2014. p. 302-304. 
Por isso, como concluído com propriedade por Robson Renault Godinho (2016, p. 483), “O CPC somente fixa prazo para a propositura da ação principal em caso de efetivação da tutela cautelar, liminar ou final, a fim de conferir alguma segurança a quem sofreu seus efeitos", até porque sem a concessão da medida cautelar e sua efetivação não há eficácia a ser suspensa, não havendo a necessidade de que o legislador fixasse prazo para o ajuizamento da ação principal.

Ressalte-se, que o $\S 1^{\circ}$, do art. 308, do CPC autoriza, ainda, a cumulação inicial do pedido principal com o cautelar, hipótese essa em que a tutela cautelar não será antecedente, mas sim, incidental. (DIDIER JR.; BRAGA; OLIVEIRA, 2016, p. 628).

Com efeito, apresentado o pedido de tutela satisfativa, as partes serão intimadas, na pessoa dos seus advogados (ou sociedade de advogados) ou pessoalmente, para comparecer à audiência de conciliação ou de mediação, na forma do art. 334, do CPC, sem necessidade de citação do réu (art. 308, $\S 3^{\circ}$, CPC).

Em verdade, o objetivo primordial dessa audiência é a tentativa de autocomposição da lide, a se dar mediante a conciliação das partes, antes do início da fase específica da instrução processual. No entanto, diz o $\S 4^{\circ}$, do art. 308, do CPC, que em não havendo a autocomposição o prazo de 15 dias para o réu apresentar sua contestação será contado a partir da audiência ou, frustrada a realização desta, a partir dos momentos indicados pelos incisos do art. 335 do CPC.

Na sequência, o juiz observará o procedimento comum até a prolação da sentença em que julgará o pedido de tutela cautelar em definitivo, para confirmala, modifica-la ou revoga-la, bem como para julgar o pedido de tutela satisfativa definitiva (ou seja, o pedido principal).

Por sua vez, os incisos I a III, do art. 309, do CPC trazem as hipóteses em que haverá a cessação da eficácia da tutela concedida em caráter antecedente. São elas: o autor não deduzir o pedido principal no prazo legal (inciso I); não for efetivada no prazo de 30 (trinta) dias (inciso II); e se o juiz julgar improcedente o pedido principal formulado pelo autor ou extinguir o processo sem resolução de mérito (inciso III). 
Decerto, esse dispositivo legal não trouxe novidades significativas e, em essência, reproduziu texto tradicional na legislação anterior ${ }^{88}$. Todavia, é oportuno destacar que a despeito do silêncio da lei, se a sentença for de procedência do pedido principal, após efetivado e satisfeito o direito objeto do pedido, cessará a eficácia da tutela cautelar concedida em caráter antecedente, por força da orientação inserta no Enunciado 504, editado pelo Fórum Permanente de Processualistas Civis ${ }^{89}$.

$\mathrm{Na}$ eventualidade de haver a cessação da eficácia da tutela cautelar por uma das causas dos incisos do art. 309, do CPC, a parte não poderá renovar o pedido respectivo, salvo com base em fundamento diverso do anterior. Logo, deve ser formulada uma nova tutela cautelar.

Outrossim, importa destacar que o indeferimento da tutela cautelar não impede que a parte formule o pedido principal e nem irá influenciar no julgamento desse. Todavia, se o indeferimento for motivado pelo pronunciamento sobre a decadência ou prescrição do direito acautelado, haverá a formação de coisa julgada, razão pela qual não poderá ser formulado o pedido de tutela definitiva, até porque, a rigor, já terá sido objeto de julgamento com cognição exauriente (art. 310, do CPC).

Por derradeiro, faz-se um adendo para ressaltar que a tutela cautelar requerida em caráter antecedente não está sujeita à estabilização, diferentemente da tutela antecipada.

Os motivos são sintetizados por Adriano Soares da $\operatorname{Costa}^{90}$, quais sejam: a sua finalidade é simplesmente acessória da pretensão assegurada (não do processo); se não houver o exercício da pretensão assegurada, a pretensão a assegurar se extingue; a sua natureza é sempre temporária e nunca se tende à definitividade.

\footnotetext{
${ }^{88}$ Há adendo feito por Robson Renault Godinho (2016, p. 484): "Deve ser ressalvada a hipótese, também já bem identificada no CPC/1973, de, excepcionalmente, a sentença de improcedência não acarretar na eficácia da tutela cautelar, caso persista o perigo de dano, o que pode ocorrer antes do trânsito em julgado da sentença de improcedência, e, com mais razão, da sentença de procedência, podendo incidir inclusive na fase de cumprimento.".

${ }^{89}$ De acordo com o Enunciado 504, editado pelo Fórum Permanente de Processualistas Civis: "Cessa a eficácia da tutela cautelar concedida em caráter antecedente, se a sentença for de procedência do pedido principal, e o direito objeto do pedido foi definitivamente efetivado e satisfeito. (Grupo: Tutela de urgência e tutela de evidência).”.

${ }^{90}$ COSTA, Adriano Soares da. Morte processual da ação cautelar? In: COSTA, Eduardo José da Fonseca; DIDIER JR., Fredie; GOUVEIA FILHO, Roberto P. Campos; PEREIRA, Mateus Costa (Orgs.). Tutela provisória. Coleção Grandes Temas do Novo CPC. Salvador: Juspodivm, 2016. p. 37.
} 
Em todo o caso, reserva-se essa oportunidade para informar que as controvérsias envolvendo a temática da estabilização da tutela antecipada requerida em caráter antecedente serão abordadas no próximo capítulo.

\section{4}

\section{Fungibilidade}

Como é cediço, o Código de Processo Civil de 2015 uniformizou os pressupostos que autorizam a concessão das tutelas de urgência, prevendo um regime comum para seu deferimento em caráter incidental.

Não obstante isso instituiu procedimentos diferenciados para a concessão da tutela de urgência antecedente antecipada (satisfativa) e cautelar. Assim é que a tutela de urgência antecipada está prevista nos arts. 303 e seguintes do CPC, e a tutela de urgência cautelar, nos arts. 305 e seguintes desse mesmo diploma legal.

Em decorrência das diferenças e das dificuldades práticas decorrentes, sobretudo a possibilidade de estabilização da tutela satisfativa provisória, o legislador foi cauteloso ao prever a fungibilidade dessas tutelas de urgência requeridas em caráter antecedente, exigindo a adaptação do procedimento.

De acordo com o art. 305, parágrafo único, do CPC, requerida a tutela cautelar em caráter antecedente, se o juiz entender que sua natureza é satisfativa (antecipatória), poderá assim recebê-la, seguindo o rito respectivo disposto no art. 303, do CPC.

Isso é o que a doutrina intitula de fungibilidade progressiva, isto é, a conversão da medida cautelar em satisfativa (ou da menos agressiva para a mais agressiva).

Ocorre que, não existe previsão expressa em sentido inverso, ou seja, a possibilidade de ser observado o procedimento da tutela cautelar em caráter antecedente, se constatado que o pedido do requerente tratado como de "tutela antecipada”, em verdade, seja de natureza cautelar.

Não obstante isso, Fredie Didier Jr., Paula Sarno Braga e Rafael Alexandria de Oliveira admitem essa possibilidade, ao argumento de que,

se o legislador admite essa fungibilidade progressiva (da cautelar para a satisfativa), deve-se admitir, por analogia, a fungibilidade regressiva satisfativa para a cautelar (da mais para a menos agressiva e rigorosa). (DIDIER JR.; BRAGA; OLIVEIRA, p. 630). 
Nesse caso, uma vez requerida tutela provisória satisfativa (antecipada) em caráter antecedente, se o juiz entender que sua natureza é cautelar, poderá assim recebê-la, desde que seguindo o rito para ela previsto em lei. Mas, a doutrina adverte sobre a necessidade de que essa decisão tenha motivação clara nesse sentido, especialmente para que o réu saiba das consequências de sua inércia, evidentemente mais gravosas acaso o pedido seja de tutela provisória satisfativa.

Nesse sentido, Bruno Garcia Redondo a afirmar que:

(...) a "fungibilidade" entre as tutelas provisórias de urgência (antecipada e cautelar) deva ser recíproca. O parágrafo único do art. 305 estabelece que, quando o autor, a título de tutela cautelar antecedente, formular requerimento cuja natureza seja, na realidade, de tutela antecipada antecedente, deverá o juiz (...) ajustar o procedimento à sistemática do art. 303. A recíproca, por consequência, deve ser verdadeira. Se o autor requerer tutela antecipada antecedente e o juiz considerar que a petição veicula requerimento de tutela cautelar antecedente, deve o magistrado oportunizar a adaptação do procedimento para que a causa tramite pelo procedimento dos arts. 305 e seguintes. (REDONDO, 2015, p. 170).

Logo, é admitida uma fungibilidade de mão dupla, exigindo-se, contudo, que venha acompanhada da conversão do procedimento inadequado para aquele que é o adequado por força de lei.

De toda sorte, não se pode deixar de olvidar que podem haver problemas práticos na identificação da tutela provisória almejada para fins de estabilização prevista pelo art. 304, do CPC, que, como será visto, é restrita a tutela satisfativa antecedente, e inaplicável para a cautelar.

Por conseguinte, José Herval Sampaio Júnior ${ }^{91}$ propõe uma solução ao magistrado: antes de decidir pela alteração da natureza da tutela e do procedimento que será observado deverá implementar o contraditório substancial, na forma do artigo 10 do CPC/2015, evitando que sejam proferidas decisões indesejáveis. Veja seus argumentos:

Interessante previsão ainda é a fungibilidade inserta no parágrafo único do artigo 305 "Caso entenda que o pedido a que se refere o caput tem natureza antecipada, o juiz observará o disposto no art. 303", o que nos autoriza a concluir pela patente implementação do contraditório substancial como norma fundamental do novo CPC em diversos artigos, que o juiz deve anunciar a tese que entende pertinente e aí possibilitar o devido ajuste, pois como dizemos em nota de rodapé a estabilização não pode ocorrer em tutela cautelar, logo em havendo mudança de espécie urgencial

${ }^{91}$ SAMPAIO JR., José Herval. Tutela cautelar no novo CPC. In: COSTA, Eduardo José da Fonseca; DIDIER JR., Fredie; GOUVEIA FILHO, Roberto P. Campos; PEREIRA, Mateus Costa (Orgs.). Tutela provisória. Coleção Grandes Temas do Novo CPC. Salvador: Juspodivm, 2016, v.6. p. 312 313. 
o autor tem que aceitar tal mudança ou então recorrer da decisão que não considera acertada e não haver a mudança de plano pelo juiz, pois repita a ideia inicial aqui esposada, o autor poderá querer, por exemplo, a antecipação e não o acautelamento, sendo o primeiro na prática bem mais restritivo a parte adversa. Entretanto, quando se pede tutela cautelar e o juiz entende que é caso de tutela antecipada de ofício, parece-nos que na prática não teremos qualquer problema, pois para nós o autor restará atendido de modo mais amplo do que requereu, o que não acontece na fungibilidade inversa, como já destacado, logo temos que nos acostumar com a ideia sempre de contraditório e seu corolário do dever de consulta e direito de ser influenciado pelas considerações das partes, isso para o juiz, sempre evitando que este profira decisões surpresas que possam prejudicar qualquer das partes.

Vale ressaltar que para Cassio Scarpinella Bueno ${ }^{92}$, o parágrafo único, do artigo 305 , representa um resquício de fungibilidade que deriva do $\S 7^{\circ}$, do art. 273 , do CPC de 1973, e que tanto quanto naquele Código, merece ser interpretado amplamente para albergar, também, a hipótese inversa, qual seja, a do magistrado, analisando a petição inicial fundamentada no art. 303 ('tutela antecipada' requerida em caráter antecedente), entender que o caso amolda-se mais adequadamente à 'tutela cautelar' requerida antecedentemente, determinando, por isso, a observância dos arts. 305 e seguintes.

A conta dessas considerações percebe-se que o CPC/2015 manteve a orientação do revogado CPC/1973 quanto a fungibilidade das tutelas de urgência cautelares e satisfativas, notadamente quando comparada a redação do art. $273, \S 7^{\circ}$, do CPC/73 com a do art. 305, parágrafo único, do CPC/2015.

Daí a se concluir que, se a fungibilidade das tutelas de urgência era admitida e prestigiada sob a égide do antigo Código, agora que são tratadas como espécies do mesmo gênero, devem ser observadas com maior razão.

\footnotetext{
${ }^{92}$ BUENO, Cassio Scarpinella. Manual de direito processual civil. 2. ed. São Paulo: Saraiva, 2016. p. 264.
} 


\section{5 \\ Controvérsias envolvendo a estabilização da tutela antecipada requerida em caráter antecedente}

\section{1}

\section{Noções gerais sobre a estabilização}

Com efeito, ao longo do presente trabalho foram apresentadas breves linhas discorrendo a respeito das inovações trazidas pela nova codificação processual.

Uma das questões mais intricadas e que mereceu um estudo mais detalhado, e, por isso, escolhido como tema a ser aqui desenvolvido, se refere a possibilidade de estabilização da tutela provisória de urgência antecipada (satisfativa) requerida em caráter antecedente, prevista no artigo 304, caput, do CPC/2015.

O instituto da estabilização da tutela provisória satisfativa fundada na urgência representa enriquecedora linha de evolução da tutela sumária, com base em anteriores experiências no direito comparado, cujo exemplo mais sólido é o instituto francês denominado référé, na medida em que admitiu a desvinculação entre a tutela de cognição sumária e a tutela de cognição plena ou o processo de mérito. $^{93}$

Nos termos do art. 484 do Código de Processo Civil francês, o référé é um procedimento sumário, em contraditório, perante juízo monocrático distinto do condutor do processo principal, que pode ser instaurado de forma antecedente ou incidental, e resulta em um provimento de ordem, que não pode ser suspenso em nenhum caso, sem rígida instrumentalidade com o processo de cognição plena. (FERREIRA, 2017).

A existência de um processo de mérito em curso não é pressuposto para sua concessão. Além disso, ocorrências no eventual processo de fundo não o afetam, e a extinção do processo de mérito não gera, a princípio, a sua extinção. Trata-se de procedimento rápido e simplificado, sem formalismos desnecessários: dispensa-se a constituição de advogado; cita-se o demandado para comparecer a uma audiência;

\footnotetext{
${ }^{93}$ FERREIRA, Gabriela Macedo. Estabilização da tutela de urgência antecipada no novo código de processo civil. jan. 2017. Disponível em: <http://www.cecgp.com.br/noticias/1537estabilizacao-da-tutela-de-urgencia-antecipada-no-novo-codigo-de-processo-civil-artigo-da-juizafederal-gabriela-macedo-ferreira>. Acesso em: 26 mar. 2018.
} 
o procedimento será concluído com uma decisão provisória que não tem autoridade de coisa julgada.

Sobre o tema, explica Gabriela Macedo Ferreira, citando Gustavo Bohrer Paim, que o juge dês référés é dotado de um poder de ordenar imediatamente as tutelas necessárias, próprio da jurisdição do provisório, cuja eficácia não se equipara à autoridade da coisa julgada material. Segundo essa especialista, isso se deve ao fato de que existe sempre a possibilidade de se instaurar um processo de cognição plena, não havendo qualquer eficácia preclusiva na ordem de référé. Todavia, adverte a doutrinadora no sentido de que a ordem de référé não pode ser modificada em référé, exceto no caso de surgimento de circunstâncias novas. (FERREIRA, 2017).

O principal objetivo do référé ${ }^{94}$ é resolver o problema do perigo do decurso do tempo necessário para a resolução do processo de mérito, e tem como função subsidiária evitá-lo, substituindo o procedimento e a decisão definitiva, sob uma lógica econômica de satisfação dos litigantes. Outrossim, também detém "uma função de polícia das situações manifestamente ilícitas, pois o fato de o juiz reconhecer como manifestamente ilícita determinada situação desestimula a parte perdedora de engajar o processo de mérito posteriormente.”. (FERREIRA, 2017).

Pois bem. No direito brasileiro, a estabilização da tutela antecipada foi delineada, inicialmente, no Projeto de Lei $n^{\circ} 18612005$, que previu a possibilidade da tutela provisória satisfativa ser pleiteada em procedimento antecedente ou na pendência do processo, sendo previsto o fenômeno da estabilização dos efeitos da decisão nas situações em que, caso preclusa, o réu não ingressasse com nova demanda exauriente ou requeresse o prosseguimento da ação, no prazo, respectivamente, de 60 ou 30 dias, hipótese em que tal decisão adquiriria autoridade de coisa julgada. Contudo, não foi dado seguimento ao referido Projeto de Lei.

\footnotetext{
${ }^{94}$ Note-se, que no direito italiano, há instituto similar, também inspirado no référé francês, previsto no Decreto Legislativo 5, de 17 de janeiro de 2003, acerca do processo societário. De acordo com essa legislação, aos provimentos antecipatórios de urgência não se aplica o artigo 669-octies do Código de Processo Civil italiano, desobrigando a propositura de ação principal no prazo de 30 dias. Além disso, estabelece, ainda, que se a ação principal não for proposta, a decisão antecipatória só poderá ser modificada a pedido das partes, se houver mudança nas circunstâncias. Assim, estabelece a autonomia da decisão antecipatória dos efeitos da tutela, tornando prescindível a propositura do processo de mérito. (FERREIRA, Gabriela Macedo. Estabilização da tutela de urgência antecipada no novo código de processo civil. jan. 2017. Disponível em: <http://www.cecgp.com.br/noticias/1537-estabilizacao-da-tutela-de-urgencia-antecipada-no-novocodigo-de-processo-civil-artigo-da-juiza-federal-gabriela-macedo-ferreira>. Acesso em: 26 mar. 2018).
} 
Na sequência, por meio do ato no 379\2009 do Presidente do Senado Federal, foi constituída a comissão de juristas que elaborou o Projeto de Lei n. 16612010, aprovado por essa casa legislativa em 15 de dezembro de 2010. Seu artigo n. ${ }^{\circ} 280$ estabelecia que no mandado de citação da tutela provisória requerida de forma antecedente, haveria a advertência de "não impugnada a decisão ou medida liminar eventualmente concedida, ela continuaria a produzir efeitos independentemente da formulação de pedido principal pelo autor.". ${ }^{95}$

De toda a sorte, somente em março de 2015, o Projeto de Lei no 166/2010 foi sancionado pela Presidência da República, após ser aprovado em ambas as casas, inserindo-se, definitivamente, o instituto da estabilização da tutela no Direito Processual Civil brasileiro.

Decerto, admitiu o novo Código de Processo Civil que se estabilize a decisão proferida em sede de tutela de urgência satisfativa postulada em caráter antecedente ao pedido principal, ainda que o processo respectivo seja extinto e sem que se dê sequência a um procedimento próprio ao trâmite de um processo principal ou de cognição plena.

Entrementes, o art. 304 do CPC dispõe que a tutela antecipada satisfativa “torna-se estável se da decisão que a conceder não for interposto o recurso respectivo.”. E o art. 304, $\S 1^{\circ}$, complementa esclarecendo que, nesse caso, o processo será extinto e a tutela de urgência continuará a produzir seus efeitos concretos.

Em outros termos, a estabilização ocorre quando a tutela antecipada é concedida em caráter antecedente e não é impugnada pelo réu, litisconsorte ou assistente simples. Em consequência, essa decisão permanecerá produzindo efeitos enquanto não for ajuizada ação autônoma para revisá-la.

A toda a evidência, por viabilizar a obtenção de resultados práticos a partir da inércia do réu, a estabilização da tutela antecipada configura-se como uma modalidade de técnica monitória para situações de urgência e para a tutela satisfativa.

\footnotetext{
${ }^{95}$ BRASIL. Senado Federal. Projeto de Lei 166, de 2010. Dispõe sobre a reforma do código de processo civil. Disponível em: <https://www25.senado.leg.br/web/atividade/materias//materia/97249>. Acesso em: 22 abr. 2018.
} 
A técnica monitória tem por função estabilizar a produção de resultados concretos em prol do autor naqueles casos em que o réu, podendo dispor de seu direito de defesa, abre mão de impugnar a medida concedida.

Assim é que para, Fred Didier Junior, Paula Braga e Rafael Oliveira (2016, p. 617) a estabilização amplia a ação monitória, pois o legislador generaliza a técnica monitória de modo a introduzi-la no procedimento comum para todos os direitos prováveis e em perigo, que tenham sido objeto de tutela satisfativa provisória antecedente.

Não obstante isso advertem esses doutrinadores (2016, p. 617), de que o modelo da ação monitória (arts. 700 a 702, CPC) deve ser considerado o geral, mas, sem prejuízo, sugerem a possibilidade de existência de um microssistema de técnica monitória formado pelas regras da ação monitória e pelos arts. 303 a 304, que, por sua vez, se complementariam reciprocamente.

Com efeito, muito embora o dispositivo legal (art. 304, CPC/15) não preveja óbices específicos à estabilização dos efeitos da decisão que deferiu a tutela antecipada requerida de forma antecedente, há óbices gerais e sistemáticos identificados pela doutrina para impedir a estabilização em algumas hipóteses.

Neste sentido, resume Bruno Garcia Redondo (2015, p. 167-194) a posição que predomina na doutrina acerca dos principais limites à estabilização:

(i) quando o réu for citado por edital ou com hora certa, se for incapaz sem representante legal (ou com interesses colidentes) ou se estiver preso; (ii) quando se tratar de direito indisponível ou for caso de situação em que, ainda que inexistisse contestação, ficaria impedida a produção do efeito material da revelia; e (iii) quando o pedido antecedente referir-se a tutela declaratória ou constitutiva, para as quais entende-se, majoritariamente, que não cabe a técnica da antecipação de efeitos.

Na primeira hipótese, é defeso imputar as consequências da estabilização se o réu não comparecer ao processo. Entretanto, acredita-se que deva lhe ser nomeado um curador especial, que, nessa condição, poderá adotar as medidas cabíveis em sua defesa, dentre elas, inclusive, impugnar a medida urgente.

Note-se que idêntico raciocínio deve ser aplicado se o réu for incapaz sem representante legal (ou com interesses colidentes com o do representante) ou estiver preso (art. 72).

Outra limitação à estabilização se refere aos direitos indisponíveis. Estes, inclusive, servem de amparo para aqueles que se posicionam contrariamente à estabilização em relação a Fazenda Pública. 
Isto porque, em linhas gerais, tal como ocorre na hipótese de revelia, põe-se em debate a possibilidade da omissão do ente público em juízo ter como efeito a disposição de direitos indisponíveis, com violação ao interesse público.

Em todo o caso, Bruno Garcia Redondo (2015, p. 167-194) entende que seria possível essa estabilização em face da Fazenda Pública em virtude de dois argumentos. Inicialmente, porque o art. $700, \S 6^{\circ}$, do CPC, na mesma linha de entendimento do enunciado sumular n. 339 do STJ $^{96}$, consagrou o entendimento favorável ao cabimento de ação monitória contra o Poder Público. Ademais disso, sustenta o ilustre professor que "não há formação de coisa julgada, sendo permitido, à Fazenda, propor ação de modificação em até 02 anos", ao passo que somente haveria formação de coisa julgada material ${ }^{97}$ se o Poder Público restar inerte durante o biênio.

Outrossim, merece registro a lição de Leonardo Carneiro da Cunha ${ }^{98}$, que apresenta algumas situações limitantes à estabilização, notadamente em face da Fazenda Pública:

Nos casos em que se permite a tutela de urgência contra o Poder Público, é possível haver tutela satisfativa antecedente, com a consequente estabilização. Não se permite estabilização para antecipar condenação judicial e permitir a imediata expedição de precatório ou de requisição de pequeno valor. Isso porque a expedição de precatório ou de requisição de pequeno valor exige prévia coisa julgada. Nesse sentido, tem-se uma incompatibilidade entre a lógica do procedimento (urgência) com a necessidade da prévia inscrição em precatório.

Percebe-se que referido autor concebe a possibilidade de haver estabilização da tutela satisfativa antecedente em face da Fazenda Pública. No entanto, de forma resumida, apresenta algumas situações em que não seria possível tal estabilização.

Por fim, cumpre compreender a outra limitação apresentada pela doutrina, qual seja: quando o pedido antecedente se referir à tutela declaratória ou constitutiva, para as quais se entende, majoritariamente, que não cabe a técnica da antecipação de efeitos.

Com efeito, não se admite que as situações jurídicas constitutivas ou declaratórias possam ter uma eficácia provisória em razão dos riscos de

\footnotetext{
${ }^{96}$ Diz o verbete da súmula 339, do STJ: "É cabível ação monitória contra a Fazenda Pública.”.

${ }^{97} \mathrm{O}$ entendimento desse doutrinador é de que haverá a formação de coisa julgada material. Mas há divergência sobre o assunto, que será abordada ao longo desse trabalho.

${ }^{98}$ CUNHA, Leonardo Carneiro da. A fazenda pública em juízo. 13. ed. São Paulo: Forense, 2016. p. 315 .
} 
"irreversibilidade" e "instabilidade" que tais provimentos podem causar às relações sociais dela dependentes. Inobstante isso, nada impede a tutela de urgência antecipatória de mérito quanto aos seus efeitos práticos, que estejam intimamente relacionados com a situação de urgência a ser debelada. Porquanto, não se antecipa a eficácia jurídica do próprio provimento declaratório ou constitutivo.

Neste sentido, Marcelo Abelha Rodrigues ${ }^{99}$ a afirmar que:

Contudo, a dificuldade de se antecipar a tutela da própria pretensão constitutiva ou declaratória permanece porque culturalmente não admitimos que as situações jurídicas constitutivas ou declaratórias possam ter uma eficácia provisória em razão dos riscos de "irreversibilidade" e "instabilidade" que tais provimentos podem causar às relações sociais dela dependentes. Exatamente por isso, construiu-se a argumentação jurídica de que até mesmo nas ações constitutivas positivas ou negativas, bem como nas declaratórias positivas ou negativas, a tutela de urgência antecipatória de mérito se mostra viável na medida em que o que será antecipado não será o mérito stricto sensu, isto é, o próprio provimento constitutivo ou declaratório (efeito jurídico do pedido), mas sim seus efeitos práticos que estejam intimamente relacionados com a situação de urgência a ser debelada. (...). Na verdade, o que se antecipa é a eficácia social (efeitos práticos) no mundo prático e concreto de uma situação específica que esteja em risco pela urgência, mas não se antecipa a eficácia jurídica do próprio provimento constitutivo ou declaratório, que só virá ao final.

Nesse aspecto, em se admitindo a possibilidade de se antecipar os efeitos (práticos) da tutela declaratória ou constitutiva, questão diversa é investigar se tais efeitos podem ser estabilizados no tempo, na forma do art. 304 do CPC/15.

Para Eduardo Talamini ${ }^{100}$, a despeito da antecipação de tais efeitos e de sua pretensa estabilização, sempre continuará havendo necessidade e interesse do autor na busca pela tutela jurisdicional final, apta para debelar de forma definitiva a crise de situação ou de certeza jurídica.

Em outros termos, de acordo com o referido autor, muito embora não haja óbice à estabilização de tais efeitos, a tutela declaratória e constitutiva só tem serventia ao jurisdicionado se forem revestidas da estabilidade da coisa julgada material, de modo que, nesses casos, o próprio autor da medida urgente estabilizada terá interesse de promover ação de cognição exauriente, na forma do art. 304, § $2^{\circ}$, $\mathrm{CPC} / 15$.

${ }^{99}$ RODRIGUES, Marcelo Abelha. Manual de direito processual civil. 5. ed. São Paulo: RT, 2010. p. 426-427.

100 TALAMINI, Eduardo; WAMBIER, Luiz Rodrigues. Curso avançado de processo civil: cognição jurisdicional (processo comum de conhecimento e tutela provisória). 16. ed. São Paulo: RT, 2016. v. 2. p. 894-895. 
A toda a evidência, através da estabilização há sobreposição dos valores rapidez e efetividade "ao valor segurança jurídica; mediante a aplicação de um procedimento diferenciado do procedimento comum.". (OLIVEIRA NETO; MEDEIROS NETO; OLIVEIRA, 2015, p. 640). Em suma, há uma redução significativa do curso do processo, dispensando-se uma análise mais aprofundada do mérito, que seria proferida em cognição exauriente, sob a presunção de que as partes, inertes diante da decisão liminar estão satisfeitas com a tutela concedida. ${ }^{101}$

Para Heitor Vitor Mendonça Sica ${ }^{102}$ o objetivo primordial da técnica de estabilização é:

(...) tornar meramente eventual e facultativo o exercício de cognição exauriente para dirimir o conflito submetido ao Estado-Juiz, desde que tenha havido antecipação de tutela (fundada, por óbvio, em cognição sumária) e que o réu não tenha contra ela se insurgido. Sumarizam-se, a um só tempo, a cognição e o procedimento.

Logo, os principais objetivos da estabilização podem ser resumidos em afastar o perigo da demora com a tutela de urgência e oferecer resultados efetivos e imediatos diante da inércia do réu.

Ocorre que, para que sejam alcançados esses objetivos, a lei exige a satisfação de alguns pressupostos, que serão detalhados a seguir:

\section{2 Pressupostos da estabilização}

Com efeito, os pressupostos para a estabilização da tutela provisória satisfativa não foram disciplinados pelo legislador de maneira clara, de modo que coube a doutrina sintetizá-los a partir da leitura dos artigos 303, 304, caput e 304, $\S 1^{\circ}$, todos do Código de Processo Civil.

Decerto, de acordo com a redação desses dispositivos legais, uma vez concedida a antecipação em caráter antecedente, se a decisão concessiva não for impugnada pelo réu com a interposição do recurso cabível, ocorrerá a estabilização dessa decisão, com a consequente extinção do processo.

\footnotetext{
${ }^{101}$ Nesse sentido, OLIVEIRA NETO; MEDEIROS NETO; OLIVEIRA, 2015, p. 640.

${ }^{102}$ SICA, Heitor Vitor Mendonça. Doze problemas e onze soluções quanto à chamada "estabilização da tutela antecipada". Revista do Ministério Público do Rio de Janeiro. n. ${ }^{\circ}$ 55, jan/mar 2015, p. 87. Disponível em: < http://publicacao.mprj.mp.br/rmprj/rmprj_55/files/assets/basichtml/page90.html>. Acesso em: 16 abr. 2018.
} 
Nesse aspecto, há relevante divergência doutrinária sobre o tema, o que, de certo, será detalhadamente exposto mediante a apresentação dos seus principais posicionamentos, contribuindo-se, pois, para a melhor compreensão da matéria.

\subsection{1 \\ Requerimento de tutela provisória satisfativa antecedente}

Na visão de Fredie Didier Jr., Paula Sarno Braga e Rafael Alexandria de Oliveira (2016, p. 618), o primeiro pressuposto da estabilização decorre da leitura de trecho do art. 304, caput, do CPC, segundo o qual, "a tutela antecipada, concedida nos termos do art. 303 (...).”. Ou seja, para que o autor se beneficie com a estabilização deverá indicar na petição inicial que pretende valer-se do benefício previsto no art. 303, caput, do CPC, tal como exige o $\$ 5^{\circ}$, do ordenamento processual, isto é, a opção pela tutela antecedente deve ser declarada expressamente pelo autor, notadamente porque somente ela tem a aptidão para estabilizar-se nos termos do art. 304 do CPC.

Nesse mesmo sentido, Heitor Vitor Mendonça Sica ressalta a necessidade de requerimento expresso da tutela antecipada em caráter antecedente, acrescentando que:

(a) à "tutela provisória de evidência" (arts. 294, par. ún. e 311); (b) à "tutela provisória de urgência cautelar" (art. 294, caput, 301, 305 e310), e, finalmente, (c) à tutela provisória requerida em caráter "incidental" (art. 294, caput, e 295). Resta apenas a tutela provisória de urgência antecipada (satisfativa) pedida em caráter antecedente.(...) claramente o art. 303 dá duas alternativas ao autor: (a) pleitear, exclusivamente, a tutela provisória urgente satisfativa (e apenas "indicar" o pedido de tutela final); ou (b) desde logo, pedir, concomitantemente, a tutela provisória urgente satisfativa e a tutela final. Apenas na primeira hipótese que se cogitaria da possibilidade de aplicação da tese de estabilização. Isso porque o autor que formula desde logo o pedido de tutela final, a meu ver, manifesta inequivocamente a vontade no sentido de que não se contentará apenas com a tutela provisória estabilizada. (SICA, 2015, p. 88-90).

Em sendo assim, a partir do momento em que o autor manifesta sua opção pela concessão da tutela provisória satisfativa em caráter antecedente, sabe-se, de antemão, que pretende vê-la estabilizada, mas, obviamente, se preenchidos todos os requisitos autorizadores desse pleito.

Vale dizer, porém, que para essa corrente não é possível a estabilização da tutela antecipada requerida em caráter incidental, posição essa que não se coaduna com a de Teresa Arruda Alvim Wambier, Maria Lúcia Lins Conceição, Leonardo 
Feres da Silva Ribeiro e Rogério Licastro Torres de Mello ${ }^{103}$, que se manifestam pela admissão da estabilização em tutelas antecipadas requeridas incidentalmente.

De toda sorte, há que prevalecer o entendimento no sentido de que a intenção do legislador foi a de assegurar a aplicação dessa técnica apenas em relação ao procedimento de requerimento de antecipação da tutela em caráter antecedente, mormente por tratar-se de um procedimento próprio a tornar mais ágil a prestação da tutela jurisdicional.

Assim, se o autor pretende valer-se do benefício da tutela antecipada antecedente deverá requerê-lo no bojo da petição inicial, o que faz presumir o interesse na sua estabilização.

\subsection{2 \\ A existência de decisão deferindo o pedido de tutela provisória de urgência satisfativa requerida em caráter antecedente}

O segundo pressuposto se respalda na mesma redação do art. 304, caput, do CPC, qual seja: "a tutela antecipada, concedida nos termos do art. 303 (...).”. Portanto, significa isto dizer que, para que a decisão tenha aptidão para estabilizarse, é preciso que exista uma decisão concessiva da tutela provisória satisfativa (tutela antecipada) em caráter antecedente.

Note-se que a doutrina, a exemplo de Fred Didier Junior, Paula S. Braga e Rafael. A. de Oliveira (2016, p. 620), reconhece a possibilidade de estabilização dos efeitos da decisão concessiva proferida pelo juízo de primeiro grau, da decisão (unipessoal ou colegiada) concessiva em sede de recurso de agravo de instrumento interposto contra decisão singular denegatória, e da decisão proferida em processo de competência originária de tribunal, como no caso da ação cível originária a

\footnotetext{
103 “(...) não se pode perder de vista que o pedido de tutela antecipada antecedente é medida excepcional, justificando-se diante de uma urgência contemporânea à propositura da ação (art. 303), ou seja, a impossibilidade de, naquele determinado momento, dada a urgência, instruir adequadamente a ação que contemple o pedido final. Sendo assim, no mais das vezes, a tutela antecipada continuará a ser requerida tal como no sistema do CPC/73 - ou seja, liminarmente no bojo de um processo definitivo já instaurado, com petição inicial que contemple o pedido final, dotada de cognição plena - o que restringirá sobremaneira a incidência desse dispositivo. A melhor interpretação, segundo pensamos, é aquela que confere a maior eficácia possível ao instituto, admitindo-se, assim, a estabilização mesmo no caso da tutela antecipada deferida incidentemente.". (WAMBIER, Teresa Arruda Alvim; CONCEIÇÃO, Maria Lúcia Lins; RIBEIRO, Leonardo Feres da Silva; MELLO, Rogério Licastro Torres de. Primeiros comentários ao novo código de processo civil: artigo por artigo. São Paulo: RT, 2015. p. 511-512).
} 
tramitar no Colendo Supremo Tribunal Federal. Todavia, condicionam essa viabilidade ao fato de que tudo isso ocorra antes do autor aditar a inicial para complementar a causa de pedir e formular seu pedido definitivo.

Por outro lado, divergem esses estudiosos quanto à necessidade de que a decisão tenha sido proferida liminarmente. Fred Didier Junior, Paula S. Braga e Rafael. A. de Oliveira (2016, p. 620) firmam posicionamento no sentido de que não haveria a necessidade da decisão ser proferida liminarmente, podendo igualmente sofrer os efeitos da estabilização a tutela antecipada antecedente concedida após a audiência de justificação prévia prevista no $§ 2^{\circ}$ do artigo 300 do Código de 2015.

Todavia, em sentido contrário, Heitor Vitor Mendonça Sica, expõe que a tutela antecipada requerida em caráter antecedente só poderá ser estabilizada se concedida liminarmente inaudita altera parte, consoante manifestação deduzida a seguir:

Se o juiz indeferiu a providência, e o autor emendou a petição inicial com a formulação do pedido de tutela final (art. 303, § $1^{\circ}$, I), restou descaracterizada a possibilidade de aplicação do art. 304, pelas razões expostas no item anterior. Restaria saber se a tutela provisória fosse deferida em $2^{\circ}$ grau de jurisdição, após o manejo de agravo de instrumento contra a decisão de $1^{\circ}$ grau que indeferiu a providência (art. 1.015, I) e antes que tenha havido o aditamento da peça inicial (art. $303, \S 1^{\circ}$, I). Fiel à premissa aqui acolhida, entendo que se ao tempo da decisão do tribunal o autor não houver ainda promovido a emenda à peça inicial, com a formulação do pedido de tutela final (art. 303, § $1^{\circ}$, I), pode-se cogitar da estabilização da decisão (monocrática ou colegiada) que houver deferido a medida em grau recursal (hipótese em que o réu será intimado da decisão para que se lhe dê oportunidade de recorrer). (SICA, 2015, p. 90).

Da mesma maneira, existem questionamentos quanto a possibilidade de estabilização da decisão que conceda a tutela antecipada em caráter antecedente apenas parcialmente.

Há quem sustente sua viabilidade, ao fundamento de que ela tem aptidão para a estabilização com relação à parte que atendeu ao pedido provisório do autor, hipótese esta que, em sobrevindo a inércia do réu, estabilizam-se os efeitos apenas desse capítulo decisório, prosseguindo-se a discussão restante. ${ }^{104}$

Ressalte-se, por fim, que, sobre o assunto, Bruno Garcia Redondo (2015, p. 167-194) admite ser possível a adoção da técnica da estabilização da tutela antecedente quando o pedido de tutela antecedente for concedido parcialmente, mas

${ }^{104}$ Nesse sentido: DIDIER JR.; BRAGA; OLIVEIRA, 2016. p. 621; SICA, 2015, p. 95. 
adverte que, nesse caso, não haverá cabimento para a extinção do processo, que deverá prosseguir rumo à resolução do mérito. ${ }^{105}$

\section{2 .3}

\section{Inércia do Réu}

$\mathrm{O}$ caput, do art. 304, do CPC estabelece que os efeitos da decisão que antecipou a tutela de urgência permanecerão estáveis se o réu não interpuser o recurso respectivo.

Entrementes, embora o referido dispositivo legal fale em não interposição de recurso, há polêmicas com relação a natureza jurídica do ato de resistência do réu que seja capaz de impedir a estabilização da tutela e a extinção do processo.

Decerto, há quem defenda que somente a interposição do recurso de agravo de instrumento, com fulcro no art. 1.015, I, do CPC, seria capaz de impedir a estabilização ${ }^{106}$.

Outros autores, a exemplo de Fred Didier Junior, Paula s. Braga e Rafael A. de Oliveira (2016, p. 621) entendem que a palavra "recurso", inserta no art. 304, caput, do CPC, deve ser interpretada como impugnação em grau recursal, para abarcar, além do recurso, o sucedâneo recursal, tal como a suspensão de segurança ou pedido de reconsideração - mas desde que apresentados no prazo de que dispõe para recorrer. Ou seja, para esses especialistas, além da inércia quanto à interposição do recurso em face da concessão da tutela antecipada, não pode ser apresentada contra esta decisão qualquer outro meio de impugnação pelo réu.

A toda a evidência, alguns processualistas interpretam o termo "recurso" de maneira ainda mais ampla, a fim de conceber que qualquer manifestação do réu no primeiro grau de jurisdição impede a estabilização da tutela antecipada, produzindo

\footnotetext{
${ }^{105}$ De acordo com esse doutrinador, "há outras situações em que, apesar de ser possível a adoção da técnica da estabilização da tutela antecedente, não haverá cabimento para a extinção do processo, que deverá prosseguir rumo à resolução do mérito: (i) quando o pedido de tutela antecedente referirse a somente parte do mérito (a apenas parcela do pedido formulado ou a apenas um dos pedidos cumulados), não sendo, assim, o único objeto da demanda; e (ii) quando o pedido de tutela antecedente for concedido apenas parcialmente.".

${ }^{106}$ Nesse sentido, Bruno Garcia Redondo, citando Arthur Souza (SOUZA, Artur César de. Análise da Tutela Antecipada prevista no relatório final da Câmara dos Deputados em relação ao novo CPC (LGL1197315); da tutela de evidência e da tutela satisfativa última parte. Revista de Processo. vol. 235, ano 39. São Paulo: RT, set. 2014. p. 151-186; e OLIVEIRA, Weber Luiz de. Estabilização da tutela antecipada e teoria do fato consumado. Estabilização da estabilização? Revista de Processo. v. 242, a. 40. São Paulo: RT, abr. 2015. p. 225-250.
} 
o mesmo efeito que a interposição do agravo de instrumento. Desse modo, na remota não interposição de recurso, o simples protocolo de contestação ou reconvenção, no prazo do agravo, seria capaz de afastar a estabilização.

Nessa linha, Marinoni, Arenhart e Mitidiero (2017, p. 2016) sustentam que basta a manifestação do réu “(...) inequívoca no sentido de exaurir o debate com o prosseguimento do procedimento.".

Para Bruno Garcia Redondo (2015, p. 167-194), essa conclusão se deve ao fato de que a estabilização da tutela antecedente se configura como uma sanção pela inércia do réu, de modo que acaso haja a resistência do pedido do autor por meio de qualquer dos atos acima mencionados (recursais ou não recursais), desde que em observância do prazo para agravo, fica impedida a estabilização dos efeitos da tutela antecipada antecedente e afastada a extinção do processo.

Sob essa ótica, portanto, à revelia seria pressuposto da estabilização, ou seja, se o réu não apresenta recurso, mas apresenta contestação, a tutela antecipada não se estabiliza.

Outro não é o posicionamento de Eduardo Talamini ${ }^{107}$, ao fundamento de que uma vez que na defesa estejam reunidos elementos de convicção relevantes e convincentes a afastar a tese do autor, não há razão para que o feito seja extinto com a estabilização da tutela sumária, mormente se considerado que pelo artigo 304 do CPC, o juiz pode revogar ou modificar a decisão com base no novo cenário fático probatório apresentado.

Em todo o caso, essa doutrina critica a redação literal do art. 304, afirmando que essa opção de recorrer contraria a própria essência do ordenamento processual de 2015, com vistas a evitar a recorribilidade direta das decisões interlocutórias, pois exige que o réu recorra para evitar a estabilização.

No entanto, Antônio de Moura Cavalcanti Neto discorda desse pensamento, afirmando que:

A apresentação de contestação pelo autor representa erro grosseiro, pois não há o que contestar. Quando o autor é citado para contestar no Procedimento Comum tem o dever de atacar os fatos e fundamentos da petição inicial. No caso da tutela antecipada antecedente, ele, se não se conformar, deve impugnar a decisão provisória. Ademais, nem há pedido final a ser contraditado, uma vez que o seu prazo

107 TALAMINI, Eduardo. Tutela de urgência no projeto de novo código de processo civil: a estabilização da medida urgente e a "monitorização" do processo civil brasileiro. Revista de Processo. n 209, v. 37, jul/2012. p. 29-30. 
para resposta apenas começará a correr na forma do art. $303, \S 1^{\circ}$, II e III, que remetem aos arts. 334 e 335 , todos do CPC. ${ }^{108}$

Destarte, para Fredir Didier Júnior (2016, p. 621-622) o normal é que o prazo de defesa somente se inicie da audiência de conciliação ou de mediação (art. 335, I, CPC) ou do protocolo do pedido de cancelamento desta, de modo que esse prazo de defesa demora mais para ser deflagrado do que o prazo para recurso; assim, o art. 304 não exige que se espere tanto para que se configure a inércia do réu apta a ensejar a estabilização.

Não obstante isso admite o referido especialista que, se porventura, no prazo do recurso o réu não o interpõe, mas resolve antecipar a apresentação de sua defesa, sua inércia é afastada, impedindo-se a estabilização, até porque "não se pode negar ao réu o direito a uma prestação jurisdicional de mérito definitiva, com aptidão para a coisa julgada." (2016, p. 622).

Em sentido contrário, Diele Nunes e Érico Andrade afirmam que a contestação apresentada no prazo do recurso não gera o mesmo efeito de impedir a estabilização da tutela antecipada, ao fundamento de que a opção amplia a possibilidade de estabilização atribuindo mais eficácia ao instituto; além disso, o legislador adotou posição expressa no sentido de optar pelo recurso como meio para impedir a estabilização. ${ }^{109}$

De acordo com esses autores, as versões anteriores do projeto de lei do CPC/2015 utilizavam termo mais abrangente, qual seja "impugnação", o que também indicaria a finalidade restritiva do legislador na versão final. ${ }^{110}$

De toda a sorte esses ensinamentos demonstram que a melhor interpretação do termo "recurso" é a aquela que lhe atribuiu maior amplitude, de modo a abarcar não apenas o recurso, mas qualquer manifestação do réu inequívoca no sentido de exaurir o debate com o prosseguimento do procedimento (recursais ou não recursais), desde que em observância ao prazo disponibilizado para recorrer.

\footnotetext{
${ }^{108}$ CAVALCANTI, Antônio de Moura. Estabilização da tutela antecipada antecedente: tentativa de sistematização. 2015 p. $14-15 . \quad$ Disponível em: < http://www.academia.edu/12283645/Estabiliza\%C3\%A7\%C3\%A3o_da_tutela_antecipada_ante cedente_tentativa_de_sistematiza\%C3\%A7\%C3\%A3o>. Acesso em: 25 abr. 2018.

109 ANDRADE, Érico; NUNES, Diele. Os contornos da estabilização da tutela provisória de urgência antecipatória no novo CPC e o "mistério" da ausência de formação da coisa julgada. In.: FREIRE, Alexandre; BARROS, Lucas Buril de Macedo; PEIXOTO, Ravi. Coletânea Novo CPC: Doutrina Selecionada. Salvador: Juspodivm, 2015. p. 75-76.

110 Id., 2015. p. 75-76.
} 
Em verdade, essa interpretação ampliativa traz mais eficácia a nova técnica, valorizando a reação do réu e dispensando rigorismos desacerbados e desestimulando o uso de recursos.

Sob essa ótica, inclusive, admite-se a possibilidade de inércia parcial do réu, isto é, uma vez concedida a decisão antecipatória com mais de um capítulo, ao réu é assegurada a impugnação de apenas um dos capítulos decisórios. Nesse caso, somente os capítulos decisórios não impugnados serão alcançados pela estabilização.

Outra não é a posição da doutrina:

Há que considerar, ainda, a possibilidade de inércia parcial do réu. Isso se dará quando, concedida a decisão antecipatória com mais de um capítulo, o réu só impugnar em sede de recurso, contestação ou outra via de questionamento, um dos capítulos decisórios, caso em que só os outros, não impugnados, serão alcançados pela estabilização. (DIDIER JUNIOR; BRAGA; OLIVEIRA, 2016, p. 621-623).

A despeito disso, Heitor Vitor Mendonça Sica (2015, p. 95) e Eduardo Talamini ${ }^{111}$ também reconhecem não haver óbice à estabilização na hipótese em que há recurso parcial, gerando a estabilização da demanda nos limites da matéria não atacada no recurso. Ressalvam, contudo, a hipótese de acolhimento do pedido subsidiário de tutela antecipada.

É importante destacar que não há que se falar em estabilização quando, embora o réu seja inerte, haja impugnação recursal pelo litisconsorte passivo ou assistente litisconsorcial ou simples do réu, cujos fundamentos de defesa aproveitem também o réu inerte. ${ }^{112}$

Sobre o assunto, confira a redação do Enunciado n. ${ }^{o} 501$ do Fórum Permanente de Processualistas Civis, in verbis:

a tutela antecipada concedida em caráter antecedente não se estabilizará quando for interposto recurso pelo assistente simples, salvo se houver manifestação expressa do réu em sentido contrário.

Por fim, vale dizer que se a tutela provisória for decidida pelo relator, deverá o réu interpor o recurso de agravo interno para evitar a estabilização (art. 1.021, CPC).

111 TALAMINI, Eduardo. Tutela de urgência no projeto de novo código de processo civil: a estabilização da medida urgente e a "monitorização" do processo civil brasileiro. Revista de Processo. n 209, v. 37, jul/2012. p. 31.

112 Nesse sentido: DIDIER JR.; BRAGA; OLIVEIRA, 2016, p. 622. 
Outrossim, se decidida por acórdão, não estará sujeita a recurso extraordinário, por força do enunciado n. ${ }^{\circ} 735$ do Colendo Supremo Tribunal Federal $^{113}$, mas sendo permitido o manejo de apelo especial, desde que o recurso verse sobre o preenchimento dos pressupostos da concessão da medida, a teor do decidido pela $1^{\text {a }}$ Turma do Superior Tribunal de Justiça, no REsp n. ${ }^{\circ}$ 816.050/RN, de relatoria do $\mathrm{Exm}^{\circ}$ Sr. Ministro Teori Albino Zavascki, julgado em 28 de março de 2006, publicado no DJ de 10 de abril de 2006, p. $163 .^{114}$

\section{2 .4 \\ Necessidade de aditamento da petição inicial pelo Autor}

Outra relevante questão relacionada aos pressupostos para a estabilização da tutela provisória satisfativa se refere a necessidade de aditamento à petição inicial, prevista pelo $\S 1^{\circ}$, I, do art. 303 .

De acordo com o sobredito dispositivo legal, uma vez obtida decisão liminar favorável ao autor, concedendo-lhe a tutela antecipada requerida, será o mesmo intimado para aditar o pedido inicial e o réu será citado e intimado para a audiência de conciliação ou mediação na forma do art. 334, do CPC.

Assim como esclarecido alhures, se o réu não interpuser recurso, ou outra forma de impugnação, contra a decisão que concedeu a antecipação dos efeitos da tutela, ela estabilizará seus efeitos. O autor, por outro lado, se não aditar a inicial terá seu processo extinto sem resolução de mérito (art. $303, \S 2^{\circ}, \mathrm{CPC}$ ).

Ocorre que, as redações dessas regras normativas causam inviabilidades práticas, e ganham maior importância diante do fato de que o prazo para o autor aditar a inicial parece se iniciar antes do prazo para o réu recorrer da decisão.

Em outros termos, por força da literalidade do art. $303, \S 1^{\circ}$, do CPC, o prazo de 15 (quinze) dias para o autor aditar a inicial se inicia desde a concessão da tutela antecipada em caráter antecedente, isto é, de sua intimação para a prolação da decisão, seja na já pessoa do seu advogado, através da publicação em Diário Oficial ou de intimação pelo portal eletrônico. Por outro lado, o prazo de 15 (quinze) dias para o réu apresentar o "respectivo recurso" tratado pelo art. 304 do CPC, começa

\footnotetext{
113 "Não cabe recurso extraordinário contra acórdão que defere medida liminar.".

114 "Em recurso especial contra acórdão que nega ou concede medida cautelar ou antecipação da tutela, a questão federal passível de exame é apenas a que diz respeito aos requisitos da relevância do direito e do risco de dano, previstos nos artigos 804 e 273 do CPC (...).”.
} 
a fluir em momento posterior ao da decisão e sua publicação, notadamente porque seu curso somente se iniciará após a sua comunicação, frisando que nos termos do art. 231, do CPC, esse prazo flui, em regra, da juntada aos autos, com comprovante de sua citação/intimação, ou do dia útil seguinte ao término do prazo do edital, do acesso ao portal eletrônico ou do término do prazo para consulta.

Desta feita, na prática o autor será obrigado a aditar sua inicial, com a consequente instauração da demanda principal, contudo antes da certeza quanto a conduta do réu em deixar de recorrer, acarretando, assim, a extinção do processo com a estabilização da tutela antecipada.

Porquanto, indaga-se: nessa hipótese, permanecendo inerte o réu e, a título de cautela, o autor aditar, será estabilizada a tutela ou o processo deverá continuar? Ou, se o autor não aditar, o processo será extinto e a estabilização será revogada?

A toda a evidência, a principal questão envolvendo tal controvérsia é saber quais atitudes terão aptidão para estabilizar ou evitar a estabilização.

Decerto, há quem afirme que a ausência de aditamento da petição inicial pelo autor, aliada à inércia do réu, constituiria uma dupla inércia ou omissão necessária para ocorrer a estabilização da tutela antecipada. Esta é a posição de Eduardo José Fonseca da Costa, o qual, citado por Ravi Peixoto ${ }^{115}$, apresenta o seguinte argumento:

Para Eduardo Fonseca, esse procedimento será extinto e haverá a estabilização no caso da não interposição do agravo de instrumento (art. 302, caput) e caso o autor não emende a petição inicial no prazo a ele concedido (art. 301, $2^{\circ}$ ). Em outros termos, para que haja a estabilização, o magistrado deve certificar que transcorreu o prazo recursal do réu e o prazo para a emenda por parte do autor. Assim, ambas as partes podem impedir a estabilização do processo. (...). Essa interpretação estaria mais adequada ao respeito à manifestação de vontade das duas partes, que podem ter por objetivo a continuação da cognição por qualquer motivo, mesmo que o prazo do seu adversário tenha findado primeiro, o que lhe traria uma situação de vantagem. Tanto o autor pode desejar que a tutela antecipada possa virar uma sentença de mérito e ser beneficiado pela coisa julgada, como o réu pode ter por objetivo também a coisa julgada em seu favor, para além da extinção do processo.

Por outro norte, Teresa Arruda Alvim Wambier, Maria Lúcia Lins Conceição, Leonardo Feres da Silva Ribeiro e Rogério Licastro Torres de Mello possuem

115 PEIXOTO, Ravi. Por uma análise dos remédios jurídicos processuais aptos a impedir a estabilização da tutela antecipada antecedente de urgência. In: COSTA, Eduardo José da Fonseca; DIDIER JR., Fredie; GOUVEIA FILHO, Roberto P. Campos; PEREIRA, Mateus Costa (Orgs.). Tutela provisória. Coleção Grandes Temas do Novo CPC. Salvador: Juspodivm, 2016, v. 6. p. $247-$ 248. 
entendimento no sentido de que a dupla inércia, ao invés de permitir, impediria a estabilização. Segundo eles,

É importante mencionar que não haverá estabilização da tutela antecipada, mesmo diante da ausência de recurso (ou resistência) do réu, quando o autor não aditar a petição inicial (inciso I do art. 303), o que implicará a extinção do processo (art. 303, $\left.\S 2 .^{\circ}\right)$, com a perda da eficácia da tutela antecipada deferida. ${ }^{116}$

Outro é posicionamento de Leonardo Ferres da Silva Ribeiro, que se baseia na ideia de que a tutela deverá ser estabilizada, ou não, dependendo única e exclusivamente da atitude do réu. Porquanto, a ausência do aditamento não pode ser óbice à estabilização que beneficia ao autor, sobretudo porque:

Poder-se-ia cogitar da extinção do processo com a estabilização da tutela antecipada, porquanto é conferida às partes a ação prevista no $\S 2^{\circ}$ do art. 304 para rever, invalidar ou reformar a antecipação da tutela. A vingar tal raciocínio, nenhum autor se preocupará em proceder ao aditamento que a lei lhe impõe, na medida em que o arquivamento do processo lhe favorecerá, pois obrigará o réu a ingressar com uma ação para discutir a tutela antecipada. A hipótese de extinção do processo com a estabilização da tutela antecipada deve ser confinada à hipótese de inércia do réu em não impugná-la. (RIBEIRO, 2015, p. 221).

De fato, alguns podem se perguntar se o aditamento pelo autor poderia ser considerado desistência da tutela. Sobre o assunto, Antônio de Moura Cavalcanti Neto propõe uma solução a se dar mediante a intimação do autor para informar se pretende ou não dar continuidade ao processo, por força do dever de consulta às partes, previsto no art. 10 do $\mathrm{CPC}^{117}$.

Em outros termos, entende esse doutrinador, que haverá extinção, na forma do $\S 1^{\circ}$, do artigo 304 , do Código de 2015 , somente em relação à tutela antecipada estabilizada, prosseguindo o processo para a análise exclusiva do pedido de tutela definitiva, ressaltando que o juiz, nesta situação, deverá consultar previamente o autor, para que confirme se pretende ou não prosseguir com o processo, ou seja, se está ou não satisfeito apenas com a estabilização da tutela antecipada. Nesse sentido:

\footnotetext{
116 WAMBIER, Teresa Arruda Alvim; CONCEIÇÃO, Maria Lúcia Lins; RIBEIRO, Leonardo Ferres da Silva; MELLO, Rogério Licastro Torres de. Primeiros comentários ao novo código de processo civil: artigo por artigo. São Paulo: RT, 2015. p. 512.

${ }_{117}$ Art. 10. O juiz não pode decidir, em grau algum de jurisdição, com base em fundamento a respeito do qual não se tenha dado às partes oportunidade de se manifestar, ainda que se trate de matéria sobre a qual deva decidir de ofício
} 
Diante da tutela antecipada concedida e da inércia do réu, haverá estabilização, mas o juiz percebeu que o autor aditou o seu pedido inicial. (...) Neste caso, antes de decidir, atendendo ao disposto no art. 10 do $\mathrm{CPC}$, o juiz intimará o requerente da medida para manifestar-se sobre o prosseguimento do feito. (...) Se (...) o autor manifestar interesse em ver o seu pedido apreciado no mérito, pois deseja discutir tudo aquilo que foi apontado no aditamento com a posterior atribuição de coisa julgada, o juiz determinará o prosseguimento do feito e, exclusivamente quanto à tutela antecipada antecedente, extinguirá o processo sem resolução do mérito, nos termos do $\S 1^{\circ}$ do art. 304 do CPC. (...) A única forma de compatibilizar os dispositivos, sem prejudicar a eficácia da estabilização, é aceitar que, no caso concreto, o juiz extinguirá apenas a parcela do processo que disser respeito à tutela antecipada antecedente (juízo provisório). ${ }^{118}$

O sobredito doutrinador acrescenta, que a parte poderá dar continuidade ao processo mantendo estáveis os efeitos da tutela. Logo, acaso se busque uma decisão de mérito, nada impedirá que a parte autora prossiga com o processo normalmente, usufruindo dos efeitos da tutela não impugnada. Mas, ao aditar a petição inicial e optar o autor pelo prosseguimento do feito quando questionado pelo magistrado, eventual decisão final de mérito contrária aos pleitos autorais seria capaz de revogar a tutela antecipada estabilizada.

Nesse particular, Alexandre Freitas Câmara ${ }^{119}$, mantendo parcialmente a linha de entendimento de Antônio de Moura Cavalcanti Neto, sugere, igualmente, a necessária intimação do autor - que inicialmente aditou a petição inicial - após verificada a ausência de impugnação recursal pelo réu em face da decisão concessiva da tutela antecipada. Para ele, caberá ao autor enunciar se está satisfeito com a tutela estabilizada - o que acarretará, portanto, a extinção do processo -, ou se pretende prosseguir com o feito, opção esta que afastaria de vez a estabilização.

Veja seus fundamentos:

Pode acontecer de o autor emendar a petição inicial e o réu não interpor agravo. Neste caso, terá havido uma manifestação de vontade do autor de prosseguir com o processo. Não se pode, porém, excluir a possibilidade de que o autor o tenha feito simplesmente porque não sabia se o réu iria ou não agravar, tendo então receado a extinção do processo sem resolução do mérito. Nessa hipótese, não tendo o réu interposto o recurso, só não terá havido a estabilização da tutela antecipada por ter o autor emendado a inicial, mas é possível imaginar que a ele interesse a estabilização.

118 CAVALCANTI NETO, Antônio de Moura. Estabilização da tutela antecipada antecedente: tentativa de sistematização. In: COSTA, Eduardo José da Fonseca; DIDIER JR., Fredie; GOUVEIA FILHO, Roberto P. Campos; PEREIRA, Mateus Costa (Orgs.). Tutela provisória. Coleção Grandes Temas do Novo CPC. Salvador: Juspodivm, 2016, v. 6. p. 216.

${ }^{119}$ CÂMARA, Alexandre Freitas. O novo processo civil brasileiro. 2. ed. São Paulo: Atlas, 2016. p. 163-164. Disponível em: <https://www.academia.edu/32073955/C\%C3\%82MARA_Alexandre_Freitas._O_Novo_Proces so_Civil_Brasileiro._2._ed>. Acesso em: 10 abr. 2018. 
A solução adequada para este caso, pois, será exigir do juiz que profira despacho advertindo o autor do fato de que, por não ter o réu recorrido, pode acontecer a estabilização da tutela antecipada. Esta é uma conduta cooperativa do órgão jurisdicional, resultante do modelo de processo cooperativo, comparticipativo, que se constrói a partir do art. $6^{\circ}$, devendo-se, por conseguinte, admitir que o autor desista da ação, caso em que o processo será extinto sem resolução do mérito e, automaticamente, estará estabilizada a tutela antecipada de urgência antecedente. Caso o autor não desista da ação, porém, o processo seguirá em direção a uma decisão fundada em cognição exauriente, não se cogitando de estabilização da tutela de urgência satisfativa antecedente.

Portanto, de acordo com esse entendimento, poderá o autor, ao aditar a petição inicial, declarar que só pretende o prosseguimento do processo se o réu agravar, contentando-se, pois, com a estabilização da tutela antecipada em caso contrário, hipótese em que o processo será extinto sem resolução do mérito e a tutela antecipada será declarada estável.

Por tudo isso, diante das controvérsias existentes sobre o assunto, Bruno Garcia Redondo (2015, p. 167-194) analisou a situação propondo como solução uma interpretação dos textos legais que permita a postergação do termo a quo do prazo para o aditamento pelo autor, a se dar através de duas formas de adiamento desse marco inicial: uma lege data e a outra lege ferenda.

De lege data, mediante a releitura da expressão "concedida a tutela antecipada" utilizada pelo $\S 1^{\circ}$, do art. 303 , do CPC, para que seja concebida como "efetivada a tutela antecipada", por analogia ao art. 308, do CPC, que utiliza exatamente essa palavra "efetivada" para regulamentar a tutela cautelar antecedente.

Nesse caso, portanto, se o prazo para o autor aditar a inicial se iniciar somente depois da efetivação da tutela antecipada antecedente, na prática o prazo para o réu interpor o "respectivo recurso", impugnando a decisão, já teria começado a correr, na medida em que, em tese, sua citação teria se concretizado. Daí é que, para esse doutrinador, poderá o autor, antes do início do curso de seu prazo para aditamento, verificar se o réu recorreu ou não, ao passo que em não existindo impugnação recursal pelo réu, o autor ficará dispensado do aditamento, a tutela será estabilizada e o processo será extinto (art. 304, caput e $\S 1^{\circ}$ ).

No que se refere ao adiamento lege ferenda, a solução do referido doutrinador se aperfeiçoaria com a alteração da redação dos incisos I e II, do $§ 1^{\circ}$, do art. 303, do CPC, que passaria a se apresentar nos seguintes termos: 
I - o autor deverá aditar a petição inicial, com a complementação de sua argumentação, a juntada de novos documentos e a confirmação do pedido de tutela final, em 15 (quinze) dias contados de sua intimação para contraditório ao agravo de instrumento ou à resposta do réu; e II - realizado o aditamento pelo autor, o réu será citado e intimado para a audiência de conciliação ou de mediação na forma do art. 334. (REDONDO, 2015, p. 167-194).

Desta feita, de acordo com sua proposta, na remota ausência de impugnação pelo réu haveria a estabilização da tutela antecedente e a extinção do processo sem necessidade de formulação de pedido principal pelo autor, consagrando-se, assim, pela primeira vez no Direito Processual Civil brasileiro, a possibilidade de tutela satisfativa autônoma ${ }^{120}$.

Em vista desses posicionamentos doutrinários, acredita-se que a melhor opção será conceder ao magistrado duas opções viáveis. Ou, inicialmente, fixar um prazo ampliado para o autor aditar a petição inicial, a ponto de permitir a conduta do réu após a concessão da tutela antecipada; ou, em não dilatando esse prazo, e realizado o aditamento da petição inicial pelo autor, constatada a ausência de impugnação recursal em face da decisão concessiva, intimará o autor para que manifeste seu interesse no prosseguimento do feito ou se encontra-se satisfeito com a estabilização da tutela antecipada e a consequente extinção do processo.

Outrossim, na hipótese da tutela antecipada antecedente ser concedida em grau recursal, é de se esperar que para evitar a extinção do processo e não se preocupar com a futura postura do réu, o autor, antes da interposição do recurso respectivo tenha emendado (rectius: aditado) a petição inicial no prazo de cinco dias do indeferimento da medida liminar, adequando-a nos moldes exigidos para o procedimento comum.

Assim é que, nessa hipótese, se desincumbindo desse ônus, a melhor solução a ser adotada seria a de permitir que o juiz, uma vez verificando que o réu não interpôs o recurso cabível diante da decisão concessiva proferida pelo Tribunal, intime o autor para que este enuncie sua opção ou pelo prosseguimento do processo ou pela estabilização e extinção do feito.

\footnotetext{
${ }^{120}$ Em sentido idêntico, sobre a possibilidade de se adiar o marco inicial lege ferenda, com a consagração da tutela de urgência satisfativa autônoma: CUNHA, Guilherme Cardoso Antunes da. Tutelas de urgência satisfativas autônomas. Revista de Processo. v. 227, a. 39. São Paulo: RT, jan. 2014. p. 141.
} 
A assertiva se consubstancia no fato de que, considerando que o autor emendou a petição inicial e interpôs o recurso de Agravo de Instrumento, é possível que o processo tramite normalmente na $1^{\mathrm{a}}$ instância, o que, se reputa, desnecessário, pois há a possibilidade de o autor se declarar satisfeito somente com a estabilização da decisão.

Por isso, uma outra solução interessante seria a de assegurar que nessas hipóteses o processo na origem permaneça suspenso até o julgamento do recurso de Agravo de Instrumento e o decurso do prazo do réu para impugnar a decisão do Tribunal.

\section{3}

\section{Ação autônoma com pedido de revisão, reforma ou invalidação da tutela antecipada estabilizada}

Com a estabilização da tutela antecipada, abre-se a oportunidade para qualquer uma das partes ajuizar ação autônoma com pedido de revisão, reforma ou invalidação dessa decisão que passou a ser instável (art. 304, $\S \S 2^{\circ}$ e $5^{\circ}, \mathrm{CPC}$ ).

Em outros termos, após a estabilização da tutela e a extinção do processo, não se admite a apresentação de simples petição, nos próprios autos originais, com o objetivo de modificar a decisão estabilizada. Decerto, a parte que deseja a revisão, a reforma ou a invalidação da tutela antecipada requerida em caráter antecedente deverá propor uma nova demanda.

A toda a evidência, os efeitos da decisão estabilizada serão conservados até que sobrevenha decisão nos autos dessa ação autônoma. Por essa razão, Fred Didier Junior, Paula S. Braga e Rafael A. de Oliveira (2016, p. 624) admitem o ajuizamento dessa ação também com o intuito de confirmar a decisão estabilizada, notadamente com o propósito de revesti-la com a autoridade da coisa julgada material.

A petição inicial da ação em questão deve ser dirigida ao juízo em que a tutela antecipada foi concedida, tratando-se, pois, de critério funcional e, portanto, absoluto de fixação de competência. Ademais, em se tratando de autos físicos, é permitido a qualquer das partes requerer o desarquivamento dos autos em que foi concedida a medida para que possam ser extraídas copias com o propósito de instruir a inicial respectiva (art. 304, §4, CPC). 


\section{4 \\ Estabilização e coisa julgada}

As regras de que cuidam os $\S \S 5^{\circ}$ e $6^{\circ}$, do art. 304, do CPC são objeto de intensa controvérsia. $\mathrm{O} \$ 5^{\circ}$ estabelece que o direito de rever, reformar ou invalidar a tutela antecipada extingue-se após 02 (dois) anos, contados da ciência da decisão que extinguiu o processo. Já o $\S 6^{\circ}$ afirma que a decisão que concede a tutela não fará coisa julgada, mas a estabilidade dos respectivos efeitos só será afastada por decisão que a revir, reformar ou invalidar, proferida nos autos de ação ajuizada por uma das partes, na forma do $\S 2^{\circ}$, do art. 304, do CPC.

A partir da leitura desses dispositivos percebe-se que a ideia desta modalidade de tutela, em especial a estabilização de tutela, é que a eficácia da decisão permaneça mesmo depois de extinto o processo, malgrado o legislador não lhe reconheça o título de coisa julgada material, a tornar-lhe imutável e indiscutível.

Desta feita, uma vez concedida a tutela antecipada antecedente, o autor terá conseguido a satisfação total ou parcial de sua pretensão, ainda que em caráter não definitivo. Entretanto, como estabelece o $\$ 5^{\circ}$, do art. 304, do CPC, se o prazo de 02 (dois) anos for ultrapassado, essa medida se tornará definitiva, sem os percalços de um processo judicial com cognição exauriente.

A opção do legislador é óbvia, pois não poderia atribuir mesma categoria processual a um pronunciamento sumário e a outro exauriente. No entanto, prever a possibilidade da extinção do processo com a tutela produzindo efeitos sem haver coisa julgada material enseja relevantes discussões. A despeito disso, questiona-se a possibilidade de formação da coisa julgada e as consequências decorrentes do esgotamento do referido prazo de 02 (dois) anos.

Não obstante isso, antes de adentrar nessa discussão, importante trazer a colação o conceito de coisa julgada nas lições de Fredie Didier Jr., Paula Sarno Braga e Rafael Oliveira (2016, p. 418), que a sintetizam como "a imutabilidade da norma jurídica individualizada contida na parte dispositiva de uma decisão judicial.”. Em outros termos, entende-se como coisa julgada material,

a indiscutibilidade da decisão judicial no processo em que foi produzida e em qualquer outro. Imutabilidade que se opera dentro e fora do processo. A decisão judicial (em seu dispositivo) cristaliza-se, tornando-se inalterável. Trata-se de fenômeno de eficácia endo/extraprocessual. (DIDIER JR.; BRAGA; OLIVEIRA, 2016, p. 419). 
Decerto, a coisa julgada é resultado da combinação de dois fatores: uma decisão jurisdicional fundada em cognição exauriente e a existência de decisão transitada em julgado. Logo, para ficar imune pela coisa julgada material, a decisão deverá conter diversos pressupostos, mas sempre deverá ter o mérito analisado em cognição exauriente.

Diferentemente, na tutela antecipada, a cognição é a sumária e, por conseguinte, pode e deve ser revista. Outrossim, apresenta-se como precária, podendo ser revogada ou modificada a qualquer tempo, desde que haja uma alteração do estado de fato ou de provas. Não é por outra razão que, "por ser assim sumária e precária, a tutela provisória é inapta a cristalizar-se com a coisa julgada material”. (DIDIER JR.; BRAGA; OLIVEIRA, 2016, p. 466).

Nesse aspecto, o Código de Processo Civil estabelece que, quando estabilizados os seus efeitos não será revista por cognição exauriente, mas tãosomente através de nova ação. Essa é a conclusão que se extrai da redação dos $\S \S 2^{\circ}$, $3^{\circ}, 5^{\circ}$ e $\$ 6^{\circ}$, do art. 304, do CPC, que para ilustrar, transcrevem-se:

Art. 304. A tutela antecipada, concedida nos termos do art. 303, torna-se estável se da decisão que a conceder não for interposto o respectivo recurso.

$\S 1^{\mathrm{o}}$ No caso previsto no caput, o processo será extinto.

$\S 2^{\circ}$ Qualquer das partes poderá demandar a outra com o intuito de rever, reformar ou invalidar a tutela antecipada estabilizada nos termos do caput.

$\S 3^{\circ}$ A tutela antecipada conservará seus efeitos enquanto não revista, reformada ou invalidada por decisão de mérito proferida na ação de que trata o $\S 2$ ․

$\S 4^{\circ}$ Qualquer das partes poderá requerer o desarquivamento dos autos em que foi concedida a medida, para instruir a petição inicial da ação a que se refere o $\S 2^{\circ}$, prevento o juízo em que a tutela antecipada foi concedida.

$\S 5$ o O direito de rever, reformar ou invalidar a tutela antecipada, previsto no $\S 2^{\mathrm{o}}$ deste artigo, extingue-se após 2 (dois) anos, contados da ciência da decisão que extinguiu o processo, nos termos do $\S 1 \stackrel{\text { o. }}{ }$.

§ 6o A decisão que concede a tutela não fará coisa julgada, mas a estabilidade dos respectivos efeitos só será afastada por decisão que a revir, reformar ou invalidar, proferida em ação ajuizada por uma das partes, nos termos do $\S 2^{\circ}$ deste artigo. ${ }^{121}$

Os efeitos da tutela estabilizada ficam conservados enquanto não houver nova ação para revisá-los, reformá-los ou invalidá-los. Entretanto, o direito a essa nova

${ }^{121}$ BRASIL. Lei n. ${ }^{\circ} 13.105$, de 16 de março de 2015. Código de processo civil. Disponível em: <http://www.planalto.gov.br/ccivil_03/_ato2015-2018/2015/lei/113105.htm〉. Acesso em: 02 abr. 2018. 
ação previsto no $\S^{\circ}$, do art. 304 extingue-se após dois anos da ciência da decisão que extinguiu o processo.

Entrementes, o prazo bienal para a propositura da ação de modificação tem natureza decadencial - não admitindo suspensão nem interrupção ${ }^{122}$, e inicia sua contagem a partir da intimação das partes sobre a decisão que determina o arquivamento dos autos. ${ }^{123}$

Pois bem. Delimitadas essas considerações, adentra-se, nessa oportunidade, nas controvérsias envolvendo o esgotamento do referido prazo de 02 (dois) anos.

Com efeito, alguns estudiosos defendem que após encerrado o prazo de 02 (dois) anos não cabe a propositura de qualquer ação tendente a modificar os efeitos da tutela estabilizados, seja por meio de ação rescisória, como também através de uma demanda autônoma destinada a debater o mérito.

Nessa linha destaca-se o entendimento de Humberto Theodoro Junior ${ }^{124}$, ao afirmar que "se a ação não for ajuizada nesse prazo, tem-se a estabilização definitiva da decisão sumária", sobretudo porque o legislador atribuiu irrefutável caráter decadencial ao prazo, não havendo a possibilidade de "suspensão ou interrupção do prazo extintivo do direito de propor a ação para rediscutir o direito em litígio.”. Para ele, inclusive, essa estabilização definitiva gera efeito similar ao trânsito em julgado da decisão, motivo pelo qual não poderá mais ser revista, reformada ou invalidada.

Sobre essa perspectiva, Artur Cesar de Souza (2014, p. 151-186) esclarece que se a ação em questão não for deduzida no prazo de 02 (dois) anos a contar da ciência do arquivamento dos autos, a estabilização da tutela concedida em caráter antecedente se tornará definitiva e não poderá ser reanalisada, sequer por ação rescisória. Assim, também para essa doutrina, "poder-se-á dizer que a tutela estará albergada pela coisa soberanamente julgada.”.

\footnotetext{
122 WAMBIER, Teresa Arruda Alvim; CONCEIÇÃO, Maria Lúcia Lins; RIBEIRO, Leonardo Ferres da Silva; MELLO, Rogério Licastro Torres de. Primeiros comentários ao novo código de processo civil: artigo por artigo. São Paulo: RT, 2015. p. 513.

${ }^{123}$ SOUZA, Artur César de. Análise da Tutela Antecipada prevista no relatório final da Câmara dos Deputados em relação ao novo CPC (LGL\1973\5); da tutela de evidência e da tutela satisfativa última parte. Revista de Processo. vol. 235, ano 39. São Paulo: RT, set. 2014. p. 151-186.

124 THEODORO JR., Humberto. Curso de Direito Processual Civil: Teoria geral do processo civil, processo de conhecimento e procedimento comum. 57. ed. Rio de Janeiro: Forense, 2016, v. 1. p. 684.
} 
Destarte, esse é o entendimento consagrado no Enunciado n. ${ }^{\text {o }} 33$ do Fórum Permanente de Processualistas Civis, segundo o qual: "Não cabe ação rescisória nos casos estabilização da tutela antecipada de urgência." 125

Por sua vez, outros especialistas sustentam que não há formação de coisa julgada da decisão que concede a tutela antecipada antecedente após o decurso do prazo de 02 (dois) anos e, por essa razão, afastam o cabimento da ação rescisória. No entanto, haveria a possibilidade de propositura de uma ação destinada a debater o mérito, dentro do prazo prescricional ou decadencial do direito material. (REDONDO, 2015, p. 167-194).

Nesse aspecto, no ano de 2012, ao analisar o projeto de lei que deu origem ao Novo Código de Processo Civil, Eduardo Talamini, respaldado pela ideia de que o instituto da coisa julgada é constitucionalmente incompatível com uma decisão proferida em sede de análise superficial, manifestou-se pela impossibilidade de que a estabilização da tutela gere coisa julgada material. Não obstante isso, concluiu que nada impede a extinção dos efeitos da medida por meio de uma demanda a ser ajuizada posteriormente. ${ }^{126}$

Essa é a posição de Mitidiero, que acrescenta não haver formação da coisa julgada em relação a estabilização da tutela antecedente, na medida em que tal instituto é próprio dos procedimentos de cognição exauriente. Por conseguinte, "passado o prazo de dois anos, continua sendo possível o exaurimento da cognição até que os prazos previstos no direito material para a estabilização das situações jurídicas atuem sobre a esfera jurídica das partes (...)." ${ }^{\text {"27. }}$

No mesmo sentido, Leonardo Ferres da Silva Ribeiro (2015, p. 230), a sustentar que diante da inexistência da coisa julgada, e uma vez obedecidos os prazos prescricionais, com o término do prazo de 02 (dois) anos as partes podem ajuizar uma nova ação com cognição exauriente sobre a mesma questão deduzida na demanda extinta.

\footnotetext{
${ }^{125}$ ENCONTRO DO FÓRUM PERMANENTE DE PROCESSUALISTAS CIVIS, 7., 2016, São Paulo. Enunciados do Fórum Permanente de Processualistas Civis. Disponível em: <http: //www.cpcnovo.com.br/wp-content/uploads/2016/06/FPPC-Carta-de-Sa\%CC\%83o-Paulo.pdf>. Acesso em: 16 abr. 2018

126 TALAMINI, Eduardo. Tutela de urgência no projeto de novo código de processo civil: a estabilização da medida urgente e a "monitorização" do processo civil brasileiro. Revista de Processo. n.. 209, v. 37, jul/2012. p. 13-34.

${ }^{127}$ MITIDIERO, Daniel. Automização e estabilização da antecipação da tutela no novo código de processo civil. Revista Magister de Direito Civil e Processo Civil, Porto Alegre, n. 63, nov/dez. 2014. p. 24-29.
} 
Cabe ressaltar que Luiz Guilherme Marinoni também compartilha desse entendimento, ao fundamento de que a legislação somente alertou que para invalidar ou reformar a decisão da tutela concedida, o réu deve propor uma ação de revisão no prazo de 02 (dois) anos. ${ }^{128}$

Por fim, há processualistas que defendem a existência de formação de coisa julgada material, e, por conseguinte, o cabimento exclusivo de ação rescisória, e não de ação objetivando discutir o mérito.

Os principais adeptos dessa corrente são Leonardo Greco e Bruno Garcia Redondo. Para Greco, ultrapassado o prazo de 02 (dois) anos da ciência da decisão que extinguiu o processo haveria a decadência do direito a propositura da ação para tentar reformar, rever ou invalidar a decisão respectiva. Em consequência, incidirá o fenômeno da coisa julgada, sendo plenamente cabível a utilização da via da ação rescisória para discutir o mérito da causa.

Segundo Redondo, a regra do $\S 6^{\circ}$, do art. 304 conduz a essa conclusão, mormente porque esse dispositivo não afirma que jamais existirá, a qualquer tempo, coisa julgada material. Há, pois, uma afirmação simples de que não há coisa julgada somente durante o período de 02 anos previsto para a ação de modificação. Em outros termos, o propósito do $\S 6^{\circ}$ é o de explicar que, "apesar da extinção do processo, não há formação de coisa julgada, razão pela qual ainda cabe, durante 02 anos, a propositura de uma ação de modificação da tutela de primeiro grau, em vez da propositura de ação rescisória. (REDONDO, 2015, p. 167-194).

Assim é que, de acordo com esse entendimento, se dentro dos 02 (dois) anos não há formação de coisa julgada, mas, após o esgotamento do biênio a estabilidade se torna imutável, é possível a formação de coisa julgada material, e, consequentemente, tornando-se cabível, apenas, a propositura de ação rescisória, sendo descabida qualquer ação autônoma destinada a rediscutir o direito material.

Em todo o caso, precipuamente no que tange à ação rescisória, Ravi Peixoto $^{129}$ se manifesta no sentido de que o Código de 2015 ampliou o seu cabimento, inclusive para casos em que não há coisa julgada. Por outro norte,

\footnotetext{
${ }^{128}$ MARINONI, Luiz Guilherme. Tutela de urgência e tutela de evidência. 1. ed. São Paulo: RT, 2017. p. 244-245.

129 PEIXOTO, Ravi. Por uma análise dos remédios jurídicos processuais aptos a impedir a estabilização da tutela antecipada antecedente de urgência. In: COSTA, Eduardo José da Fonseca; DIDIER JR., Fredie; GOUVEIA FILHO, Roberto P. Campos; PEREIRA, Mateus Costa (Orgs.). Tutela provisória. Coleção Grandes Temas do Novo CPC. Salvador: Juspodivm, 2016, v. 6. p. 246247.
} 
ressalvando a existência de entendimento admitindo o cabimento da ação rescisória nessas hipóteses, concluiu esse doutrinador que seria injustificável admitir que a tutela antecipada em caráter antecedente esteja sujeita a ser impugnada por mais dois anos por meio da ação rescisória. Segundo ele:

Aparentemente, estabilizada e ultrapassados esses dois anos, a decisão seria atingida por uma espécie de estabilidade qualificada, inexistindo outros meios para a sua impugnação. Entretanto, há quem defenda o cabimento da ação rescisória nessa hipótese. Para tanto, sustenta que, segundo o $\$ 2^{\circ}$, do art. 966, do CPC/2015, também se admite a ação rescisória contra a sentença terminativa que impeça a repropositura da demanda, o que fez ampliar o cabimento da referida ação para casos em que não há coisa julgada. Como, supostamente, não há coisa julgada na sentença terminativa, seria possível que a coisa julgada teria deixado de ser condição sine qua non para a admissão da ação rescisória, permitindo a impugnação dessa tutela antecipada por dois anos. Por mais que seja possível interpretar que o autor tenha tido o objetivo de fazer referência a ausência de coisa julgada material, não parece adequada a admissão da rescisória contra tais decisões. Há de se perceber que qualquer das partes já possui o prazo de dois anos para entrar com outra ação visando discutir amplamente a tutela antecipada anteriormente concedida. Simplesmente parece injustificável admitir que essa tutela antecipada fique sujeita a ser impugnada por mais dois anos por meio da ação rescisória.

Ressalte-se que em outro artigo, Ravi Peixoto, em conjunto com Roberto P. Campos Gouveia Filho e Eduardo José da Fonseca Costa ${ }^{130}$, descartam a possibilidade de ajuizamento de ação rescisória após o decurso do biênio para modificar a tutela antecipada estabilizada, momento em que ocorreria o fenômeno de "imutabilidade das eficácias antecipadas". Entretanto, admitem esses especialistas a discussão de outros fins em ação própria, a se materializar através do exemplo a seguir discriminado:

Numa ação relativa à obrigação de desfazer um muro houve, pela via do procedimento antecedente do art. $303, \mathrm{CPC} / 15$, a concessão de tutela antecipada, de modo a, primeiramente, possibilitar (eficácia mandamental por autorização) ao autor o desfazimento do muro que, ao que indicava, foi indevidamente construído e, em virtude disso, condenar o réu a ressarcir o autor pelos custos da demolição. Estabilizada tal decisão e transcorrido o prazo acima mencionado, não se pode mais alterar a eficácia autorizativa da demolição do muro (algo que, em termos práticos, implicar dizer que o muro não pode ser refeito). No entanto, a alegação do direito a demolir pode ser reprocessualizada para, sendo tida por improcedente, condenar o autor a indenizar o réu por eventuais danos causados pela demolição $\mathrm{O}$ dictum sentencial (declaração de existência do poder de demolir) é, pois, discutível. Se se

${ }^{130}$ COSTA, Eduardo José da Fonseca; GOUVEIA FILHO, Roberto P. Campos; PEIXOTO, Ravi. Estabilização, imutabilidade das eficácias antecipadas e eficácia de coisa julgada: um diálogo pontiano com o CPC/2015. In: DIDIER JR., Fredie; FREIRE, Alexandre; MACÊDO, Lucas Buril de; PEIXOTO, Ravi (Orgs.). Procedimentos especiais, tutela provisória e direito transitório. Coleção Novo CPC. Doutrina Selecionada. 2. ed. Salvador: Juspodivm, 2016, v. 4. p. 296-297. 
estivesse diante da verdadeira eficácia de coisa julgada a discutibilidade seria impensável, por força dos efeitos positivo e negativo que dela exsurgem. (...) o que se percebe é que após os dois anos da estabilização da tutela antecipada antecedente, não há coisa julgada e nem se pode admitir o ajuizamento de ação rescisória. O que se tem é um fenômeno novo, com características próprias - a imutabilidade das eficácias antecipadas - . Trata-se de um meio caminho entre a ampla mutabilidade das decisões antecipatórias incidentais e a coisa julgada material. Ele impede que, pela impossibilidade relativa de se discutir o dictum da decisão antecipatória, se alterem, de modo forçado a seu beneficiário, as eficácias antecipadas: a derrubada de um muro (...). O dictum nelas existente torna-se indiscutível para fins de revogar, invalidar, reformar ou modificar as eficácias que foram antecipadas. Não há, todavia, óbice à discussão para fins diversos, especialmente os de natureza indenizatória.

De toda a sorte, Eduardo Cambi e Aline Regina das Neves se inclinam para o cabimento de ação rescisória após o prazo decadencial bienal, ao argumento de que:

O direito de rever a tutela antecipada se extingue no prazo decadencial de dois anos após a ciência da decisão que extinguiu o processo. Transcorrido o prazo mencionado, resta apenas a ação rescisória para, desde que evidenciada hipótese legal para sua propositura, revisar ou reformar a decisão estabilizada. ${ }^{131}$

Por fim, importa colacionar interessante análise de Elaine Harzheim Macedo $^{132}$, a qual entende que ocorre a perempção ${ }^{133}$ após o decurso do prazo de dois anos previsto no $\S 5^{\circ}$, do artigo 304, do Código de 2015:

Trata-se (...) a perempção de hipótese absolutamente distinta da coisa julgada, que torna indiscutível e imutável o que foi decidido, não apenas em relação aos sujeitos interessados, mas também em relação aos próprios juízes, irrelevante se a questão decidida transita em jugado for arguida em sede de petição inicial ou de contestação, tanto assim que a coisa julgada pode produzir efeitos negativos ou positivos. No caso da perempção, também se alcança uma estabilização, mais voltada para o processo

131 CAMBI, Eduardo; NEVES, Aline Regina das. Acesso à justiça, tutela antecipada e técnicas processuais. In: DIDIER JR., Fredie; FREIRE, Alexandre; MACÊDO, Lucas Buril de; PEIXOTO, Ravi (Orgs.). Procedimentos especiais, tutela provisória e direito transitório. Coleção Novo CPC - Doutrina Selecionada. 2. ed. Salvador: Juspodivm, 2016, v. 4. p. 120-121.

132 MACEDO, Elaine Harzheim. Prestação jurisdicional em sede de tutela antecedente: procedimento, estabilização da decisão e decurso do prazo de 2 (dois) anos: um novo caso de perempção? Revista de Processo. vol. 250, p. 189-215. São Paulo: RT, Dez/2015. p. 206-207.

133 "No que toca à perempção como causa de extinção do processo (art. 267, V, e art. 485, V, respectivamente do CPC/1973 e do CPC/2015), a lei processual estabeleceu uma hipótese específica, tratada no art. 268 do CPC/1973 e no art. 486, $\S 3 .^{\circ}$ do CPC/2015, que consiste no fato de o autor dar causa por 3 (três) vezes à sentença extintiva fundada em abandono do processo, ficando, assim proibido de promover nova ação, sem prejuízo, porém, de alegar em defesa o seu direito. A ação lhe é tomada, vedando-se a provocação da jurisdição. Forçoso concluir, portanto, que o Código de 1973 e o Código de 2015 caminham no mesmo sentido, isto é, a perempção é perda da ação, não atingindo o direito subjetivo, que pode ser seja deduzido como forma de defesa. Quanto à pretensão, o autor não tem mais ação, ficando adstrito a arguir suas defesas na condição de demandado, isso porque não pode o autor reiteradamente negligente (deu causa por três vezes à extinção do processo, abandonando-o) provocar novamente o Poder Judiciário. A pretensão persiste, mas não tem ação.”. (MACEDO, Elaine Harzheim. Prestação jurisdicional em sede de tutela antecedente: procedimento, estabilização da decisão e decurso do prazo de 2 (dois) anos: um novo caso de perempção? Revista de Processo. vol. 250, p. 189-215. São Paulo: RT, Dez/2015. p. 206). 
do que para a ação. Mas os fundamentos são outros, pois enquanto a coisa julgada se volta para a estabilização dos conflitos, a perempção se volta para estabilizar a (inconsequente) provocação do Judiciário. A esta tradicional previsão de perempção, agrega-se agora o disposto no art. $304, \S 5 .^{\circ}$, estendendo-se o comando tanto ao autor como ao réu do processo que se extinguiu na forma do $\S 1 .^{\circ}$ desse dispositivo: ambos sujeitam-se à perempção da ação, isso porque a rediscussão da decisão provisória só ocorreria em ação que poderia ser provocada por um ou pelo outro. Contudo, se em outra demanda, que não reproduza a mesma lide (porque se assim fosse seria aplicável a perempção como forma de extinguir o futuro processo), mas com ela seja conexa, a indagação que se põe é se, nesse caso, autor ou réu podem deduzir o direito subjetivo que deu origem à decisão provisória ou que poderia, em tese, desconstituila. Considerando que ao fim e ao cabo a tutela provisória não convive com a indiscutibilidade ou a imutabilidade do que foi decidido (= julgado), atributos exclusivos da coisa julgada material, a resposta se inclina positivamente, desde que se o faça em caráter de defesa, não de ação. Não há, outrossim, qualquer estranhamento em admitir no decurso dos 2 (dois) anos a perempção - já que se trata, tradicionalmente de consequência atrelada ao autor do futuro processo - porque a ação do $\S 22^{\circ}$ tanto pode ser promovida pelo autor como pelo réu.

Em suma, para essa especialista o instituto que garante imutabilidade à decisão provisória antecedente é a perempção, pois esta é a "perda da ação, não atingindo o direito subjetivo", que poderia, então, ser deduzido como defesa. Para ela, na hipótese do autor e do réu serem inertes, não mais poderiam, após o prazo bienal, ajuizar ação para questionar aquilo que foi objeto da estabilização, malgrado permaneçam com o direito de argui-lo como forma de defesa.

Portanto, somente após o prazo do art. $304, \S 5^{\circ}$, do CPC haveria a incidência do fenômeno jurídico da perempção, impedindo o ajuizamento de nova ação para questionar a decisão estabilizada.

Trata-se de uma tese de difícil consagração, por inúmeras razões. A primeira delas, porque não se pode ter como crível que a estabilização seja relacionada a sanção pela prática de algum ilícito, pois o autor exerce legitimamente um direito que lhe assiste, qual seja, o de demandar, e o réu assente na ocorrência da estabilização.

Quanto a segunda, pelo fato de que ultimada a estabilização, uma das partes pode entender conveniente buscar a reforma ou invalidação da decisão estável, e também não há nada de ilícito nessa postura. Trata-se de um direito que assiste a ambas as partes. 
Outrossim, não há previsão legal específica de perempção para este caso, e também não há meio de se aplicar por analogia a previsão dos arts. 485, V e 486, § $3^{\circ}$, do CPC. ${ }^{134}$

Ademais disso, como se sabe, no âmbito do procedimento antecedente não se realiza o pedido principal, cabendo ao interessado somente indicá-lo. Nesse aspecto, considerando que o pedido principal foi somente indicado, não há dúvidas em se afirmar que ação principal não foi ajuizada. Logo, partindo-se dessa premissa, não há como se conceber a aplicação de sanção consubstanciada na proibição do ajuizamento de demanda principal que sequer foi proposta, lembrando, por oportuno, que o instituto da perempção foi criado para a repressão ao abuso do direito de postular em juízo.

Por essas razões, a estabilização da tutela antecipada, ainda que expirado o prazo bienal do art. 304, § 5º não dá azo à ocorrência de perempção e não constitui óbice à propositura da ação autônoma para revisão da tutela antecipada.

\section{5}

\section{Estabilização na tutela cautelar e na tutela da evidência}

Com efeito, no capítulo II - Do Procedimento da Tutela Antecipada Requerida em Caráter Antecedente - prevê o caput, do art. 304, do Código de Processo Civil que "a tutela antecipada concedida nos termos no art. 303, torna-se estável (...).”.

Logo, por força da literalidade da redação desse dispositivo legal, o CPC/2015 limitou a estabilização dos efeitos da tutela à hipótese de tutela antecipada. Todavia, há divergência doutrinária quanto ao alcance do art. 304.

Para Desirê Bauermann, por exemplo, apenas a tutela antecipada em caráter antecedente é capaz de estabilizar-se, não estendendo às medidas meramente acautelatórias ${ }^{135}$. Nesse prisma, a tutela de evidência não pode ser autonomizada $\mathrm{e}$

\footnotetext{
${ }^{134}$ Art. 485. O juiz não resolverá o mérito quando: V - reconhecer a existência de perempção, de litispendência ou de coisa julgada; Art. 486. O pronunciamento judicial que não resolve o mérito não obsta a que a parte proponha de novo a ação. § 3 o Se o autor der causa, por 3 (três) vezes, a sentença fundada em abandono da causa, não poderá propor nova ação contra o réu com o mesmo objeto, ficando-lhe ressalvada, entretanto, a possibilidade de alegar em defesa o seu direito.

${ }^{135}$ BAUERMANN, Desirê. Estabilização da tutela antecipada. Revista Eletrônica de Direito Processual - REDP, Rio de Janeiro, v. 4, p. 32-48. Disponível em: <http://www.epublicacoes.uerj.br/index.php/redp/article/view/21567/15569>. Acesso em: 18 abr. 2018.
} 
estabilizada; enquanto a tutela cautelar, embora possa ser autonomizada, não pode ser estabilizada dada a referibilidade que lhe é inerente. ${ }^{136}$

Outro não é o entendimento de Heitor Vitor Mendonça Sica (2018, p. 88), que se firma no sentido da impossibilidade da estabilização de decisão concessiva de tutela da evidência, ao argumento de que a estabilização é somente aplicável às tutelas requeridas em caráter antecedentes, dentre as quais não se inclui a tutela da evidência. Da leitura do art. 294, parágrafo único, conclui que não sendo possível requerer antecedentemente a tutela da evidência, também não será possível aplicar a estabilização.

Outrossim, no entendimento de Daniel Amorim não se aplica a estabilização na tutela cautelar, na medida em que essa espécie de tutela tem natureza meramente conservativa, não fazendo sentido estabilizar o que é conservativo. Já, quanto à evidência é favorável a aplicação da estabilização. ${ }^{137}$

No mesmo sentido, o entendimento de Teresa Arruda Alvim, Rogério Licastro Torres ${ }^{138}$ e Leonardo Ferres da Silva (2015, p. 220) ${ }^{139}$. Para Darci Guimarães Ribeiro e Marco Félix Jobim, não se aplica o dispositivo à tutela de evidência, pois esta é sempre incidente e não antecedente, de modo que nunca ocorrerá estabilização da tutela provisória. ${ }^{140}$

De toda a sorte, é oportuno relembrar que a tutela cautelar possui técnica conservativa, presumindo, assim, a existência de uma providência protetiva e temporária. A tutela deve ser mantida no tempo na medida em que houver necessidade de proteção para que, posteriormente, a parte possa ver sua pretensão satisfeita. Por conseguinte, não há como se conceber a estabilização.

\footnotetext{
${ }^{136}$ MARINONI, Luiz Guilherme; ARENHART, Sérgio Cruz; MITIDIERO, Daniel. Novo código de processo civil comentado. São Paulo: RT, 2015. p. 316.

${ }^{137}$ NEVES, Daniel Amorim Assumpção. Novo código de processo civil: Lei 13.105/2015. São Paulo: Método, 2016. p. 215.

${ }^{138}$ Para os autores a estabilização deve ser interpretada de forma ampla, apta a incidir sobre todas as formas de tutela, tanto na forma antecedente como incidental e na de evidência, ficando excluída apenas a cautelar. Cf. WAMBIER, Teresa Arruda Alvim; MELLO, Rogério Licastro Torres de; RIBEIRO, Leonardo Ferres da Silva. Primeiros comentários ao novo código de processo civil: artigo por artigo. São Paulo: RT, 2015. p. 512.

${ }^{139}$ RIBEIRO, Leonardo Ferres da Silva. Tutela provisória: tutela de urgência e tutela de evidência - do CPC/1973 ao CPC 2015. São Paulo: RT, 2015. p. 220.

${ }^{140}$ GRECO, Leonardo. A tutela da urgência e a tutela da evidência no código de processo civil de 2015. In: RIBEIRO, Darci Guimarães; JOBIM, Marco Félix. (Org.). Desvendando o novo CPC. 2 ed. Porto Alegre: Livraria do Advogado, 2016. p. 156.
} 
Nesse sentido, a conclusão do Fórum Permanente de Processualistas Civis ao editar o Enunciado n. ${ }^{\circ}$ 420, segundo o qual: "não cabe estabilização de tutela cautelar". ${ }^{141}$

Por outro lado, no tocante à tutela da evidência, diferentemente da cautelar, é de se reconhecer sua possibilidade, mormente se considerada a evidência do direito do autor e a ausência de recurso da parte contrária, de modo que seus efeitos poderão ser estabilizados, tal como ocorre com o instituto da tutela antecipada.

Desta feita, em sendo a tutela da evidência concedida e a ela não se opuser o réu, poderá ser estabilizada evitando-se assim a espera do provimento definitivo, o que, de certo, atenderia aos fins do Novel Código: a entrega de uma prestação jurisdicional célere, justa e eficiente.

${ }^{141}$ ENCONTRO DO FÓRUM PERMANENTE DE PROCESSUALISTAS CIVIS, 7., 2016, São Paulo. Enunciados do Fórum Permanente de Processualistas Civis. Disponível em: <http: //www.cpcnovo.com.br/wp-content/uploads/2016/06/FPPC-Carta-de-Sa\%CC\%83o-Paulo.pdf>. Acesso em: 16 abr. 2018. 


\section{6 \\ Conclusão}

A conta de tais considerações tem-se que o instituto da tutela provisória foi criado pelo legislador com o propósito de adequar a prestação da tutela jurisdicional as necessidades urgentes do caso concreto, que necessitam de um regramento específico para abreviar o tempo de entrega da prestação jurisdicional, sob pena de colocar em risco sua efetividade.

Em comparação com os ordenamentos processuais de 1939 e 1973, o Código de Processo Civil de 2015 conferiu maior simplicidade aos procedimentos da tutela antecipada, agrupando todas no Livro $\mathrm{V}$ da parte geral; unificando a tutela antecipada com a tutela cautelar em tutelas de urgência, e instituindo a figura da tutela da evidência.

No artigo 294 do CPC/2015, a tutela provisória encontra-se prevista como gênero que contempla as seguintes espécies: tutela de urgência e tutela da evidência.

A tutela da evidência está prevista no artigo 311, do CPC/2015, sendo requerida independentemente da comprovação do perigo de dano ou de risco ao resultado útil do processo. Trata-se de uma antecipação dos efeitos da tutela baseada na evidência do direito, se distinguindo da tutela antecipada, em razão da ausência da urgência como pressuposto para sua concessão.

A tutela da evidência visa proteger direitos evidentes, portanto aqueles cuja prova dos fatos torna praticamente certo o seu provimento, prevendo 04 (quatro) hipóteses para sua concessão. São elas: (1) abuso do direito de defesa ou o manifesto propósito protelatório da parte; (2) alegações de fato passíveis de comprovação apenas documentalmente e se houver tese firmada em julgamento de casos repetitivos (incluindo o Incidente de Resolução de Demandas Repetitivas) ou em súmula vinculante; (3) pedido reipersecutório fundado em prova documental adequada do contrato de depósito, caso em que será decretada a ordem de entrega do objeto custodiado, sob pena de multa; (4) petição inicial instruída com prova documental suficiente dos fatos constitutivos do direito do autor, a que o réu não oponha prova capaz de gerar dúvida razoável.

Destarte, apenas as hipóteses (2) e (3) podem ser requeridas liminarmente (artigo 311, parágrafo único, CPC/2015), de forma que nos demais casos, a concessão da tutela fica restrita a momento posterior à oitiva da parte contrária. 
No tocante a tutela provisória de urgência é o instrumento processual que possibilita à parte pleitear a antecipação do pedido de mérito com fundamento na urgência. Essa espécie de tutela provisória se subdivide em duas subespécies: tutela provisória de urgência antecipada - ou satisfativa do pedido; e tutela provisória de urgência cautelar - não satisfativa do pedido, sendo meramente assessória, destinada a assegurar a efetividade de outra espécie de tutela jurisdicional.

Decerto, o CPC/2015 manteve a orientação do revogado CPC/1973 quanto a fungibilidade das tutelas de urgência (cautelares e satisfativas), notadamente quando comparada a redação do art. $273, \S 7^{\circ}$, do CPC/73 com a do art. 305, parágrafo único, do CPC/2015. Daí a se concluir que, se a fungibilidade das tutelas de urgência era admitida e prestigiada sob a égide do antigo Código, agora que são tratadas como espécies do mesmo gênero, devem ser observadas com maior razão.

Note-se que, estabeleceu o novo Código duas formas para requerer a tutela provisória de urgência, quais sejam em caráter antecedente e em caráter incidental. Essa classificação considera o momento em que o pedido de tutela provisória de urgência é realizado, comparando-o com o momento em que se formula o pedido de tutela definitiva, sendo, respectivamente, antes ou conjuntamente a este pedido.

Com efeito, especificamente em relação ao requerimento antecedente, as tutelas de urgência cautelar e antecipada possuem procedimentos próprios e diferenciados, disciplinados em apartado na lei processual, sendo a técnica de estabilização prevista somente no capítulo que disciplina o procedimento da tutela antecipada requerida em caráter antecedente.

O principal objetivo da estabilização é conferir estabilidade à decisão concessiva de uma tutela antecipada antecedente, de modo que ao ser estabilizada conservará os seus efeitos práticos independentemente de uma decisão de cognição plena ao final do processo, notadamente porque o próprio processo é extinto quando a tutela é estabilizada.

Muito embora o dispositivo legal (art. 304, CPC/15) não preveja óbices específicos à estabilização dos efeitos da decisão que deferiu a tutela antecipada requerida de forma antecedente, há óbices gerais e sistemáticos que impedem a estabilização, quais sejam: (i) quando o réu for citado por edital ou com hora certa, se for incapaz sem representante legal (ou com interesses colidentes) ou se estiver preso; (ii) quando se tratar de direito indisponível ou for caso de situação em que, ainda que inexistisse contestação, ficaria impedida a produção do efeito material da 
revelia; e (iii) quando o pedido antecedente referir-se a tutela declaratória ou constitutiva, para as quais entende-se, majoritariamente, que não cabe a técnica da antecipação de efeitos.

No que se refere a impossibilidade de se imputar as consequências da estabilização se o réu não comparecer ao processo, acredita-se que a melhor opção será a nomeação de um curador especial, que, nessa condição, poderá adotar as medidas cabíveis em sua defesa, dentre elas, inclusive, impugnar a medida urgente.

Ressalte-se que idêntico raciocínio deve ser aplicado se o réu for incapaz sem representante legal (ou com interesses colidentes com o do representante) ou estiver preso (art. 72).

No tocante a limitação quanto aos direitos indisponíveis é oportuno destacar que são eles que consubstanciam a tese contrária a possibilidade de estabilização da decisão em face da Fazenda Pública. Isso se deve ao fato de tal como ocorre na hipótese de revelia, põe-se em debate a omissão do ente público em juízo ter como efeito a disposição de direitos indisponíveis, com violação ao interesse público.

Não obstante isso entende-se que não há empecilhos a essa estabilização, notadamente porque o art. $700, \S 6^{\circ}$, do CPC, ratificando o entendimento consagrado no verbete da súmula n. $^{\circ} 339$ do STJ, adotou entendimento favorável ao cabimento de ação monitória contra o Poder Público. Além disso, a estabilização não gera a formação de coisa julgada, sendo permitido que a Fazenda Pública ingresse com nova ação destinada à modificação da tutela.

Outrossim, no que tange a possibilidade de pedido antecedente referir-se a tutela declaratória ou constitutiva, foi visto que não se admite que as situações jurídicas constitutivas ou declaratórias possam ter uma eficácia provisória em razão dos riscos de "irreversibilidade" e "instabilidade" que tais provimentos podem causar às relações sociais dela dependentes. Entretanto, nada impede a tutela de urgência antecipatória de mérito quanto aos seus efeitos práticos, que estejam intimamente relacionados com a situação de urgência a ser debelada. Porquanto, não se antecipa a eficácia jurídica do próprio provimento declaratório ou constitutivo.

Destarte, a estabilização da tutela provisória satisfativa de urgência se consagra como uma das inovações mais debatidas no CPC/2015, contudo apresentando diversas problemáticas, sobretudo pelo fato do legislador ter sido 
omisso ao não considerar expressamente todas as implicações acerca da estabilização.

De fato, de acordo com as regras processuais aplicáveis ao instituto, foi visto que uma vez obtida decisão liminar concedendo a tutela antecipada em favor do autor, será o mesmo intimado para aditar o pedido, e o réu citado e intimado para, se assim o desejar, impugnar a decisão. Se o réu não interpuser o "respectivo recurso" contra a decisão que concedeu a antecipação dos efeitos da tutela, ela estabilizará seus efeitos.

Da mesma forma, viu-se que se o autor não aditar a inicial seu processo será extinto sem resolução de mérito, ao passo que em o fazendo, será dado prosseguimento a ação.

A despeito disso, existe divergência sobre o prazo inicial para aditamento da exordial pelo autor, na hipótese de deferimento do requerimento de tutela provisória de urgência requerido em caráter antecedente. Isso porque, observou-se que uma vez concedida a tutela, o inciso I, do $\$ 1^{\circ}$, do artigo 303 do CPC/2015 exige que o autor adite a petição inicial no prazo de quinze dias ou outro prazo maior determinado pelo juiz, sob pena de extinção do processo sem resolução do mérito (artigo 303, § $2^{\circ}$, do CPC).

Em vista dos posicionamentos doutrinários sobre a matéria, acredita-se que a melhor opção será conceder ao magistrado duas opções viáveis. Ou, inicialmente, fixar um prazo ampliado para o autor aditar a petição inicial, a ponto de permitir a conduta do réu após a concessão da tutela antecipada; ou, em não dilatando esse prazo, e realizado o aditamento da petição inicial pelo autor, constatada a ausência de impugnação em face da decisão concessiva, intimará o autor para que manifeste seu interesse no prosseguimento do feito ou se está satisfeito com a estabilização da tutela antecipada e a consequente extinção do processo.

Outrossim, na hipótese da tutela antecipada antecedente ser concedida em grau recursal, se concluiu que no intuito de evitar a extinção do processo e de não se preocupar com a futura postura do réu, a melhor opção a ser assegurada ao autor seria a de antes da interposição do recurso respectivo, que o mesmo proceda a emenda (rectius: aditamento) da petição inicial no prazo de cinco dias do indeferimento da medida liminar, adequando-a nos moldes exigidos para o procedimento comum. 
Nessa hipótese, se desincumbindo desse ônus, ao juiz poderia ser concedida a possibilidade de, uma vez verificando que o réu não interpôs o recurso cabível diante da decisão concessiva proferida pelo Tribunal, intimar o autor para que este enuncie sua opção ou pelo prosseguimento do processo ou pela estabilização e extinção do feito.

Decerto, considerando que o autor emendou a petição inicial e interpôs o recurso de Agravo de Instrumento, é possível que o processo tramite normalmente na $1^{a}$ instância, o que, se reputa, desnecessário, pois há a possibilidade de o autor se declarar satisfeito somente com a estabilização da decisão. Por isso, uma outra solução interessante seria a de assegurar que nessas hipóteses o processo na origem permaneça suspenso até o julgamento do recurso de Agravo de Instrumento e do decurso do prazo do réu para impugnar a decisão do Tribunal.

Sem dúvida, essas sugestões atenderiam aos princípios da economia processual, do contraditório e da segurança jurídica, evitando um desperdício do exercício da função jurisdicional com o prosseguimento do processo principal estável em função da inércia do réu.

Aliás, outra discussão envolve exatamente a natureza do ato processual que possui a capacidade de impedir a estabilização e a extinção do processo, por força da redação do artigo 304 do CPC, que estabelece que a tutela antecipada, concedida nos termos do artigo 303, se estabilizará com a ausência de interposição do "respectivo recurso" de tal decisão.

Como se sabe, alguns especialistas sustentam a interpretação restritiva do referido dispositivo, prezando por sua literalidade ao prever a não interposição do "respectivo recurso" para a estabilização da tutela antecipada. Assim é que, para eles, se concedida a tutela antecipada antecedente em primeira instância, somente o recurso de Agravo de Instrumento será capaz de obstar a estabilização. Por outro lado, há quem defenda que o vocábulo "recurso" pode ser aplicado de forma extensiva, o que permite a utilização de qualquer ato para evitar a estabilização.

De toda a sorte, tem-se que muito embora o art. 304 do CPC preveja que apenas a não interposição de recurso será apta a gerar a estabilização, acredita-se que a melhor interpretação do termo "recurso" é a mais ampla, de modo a abarcar não apenas o recurso, mas qualquer manifestação do réu inequívoca no sentido de exaurir o debate com o prosseguimento do procedimento (recursais ou não recursais), desde que em observância ao prazo disponibilizado para recorrer. 
Em verdade, essa interpretação ampliativa traz mais eficácia a nova técnica, valorizando a reação do réu e dispensando rigorismos desacerbados e desestimulando o uso de recursos.

Vale dizer que se a tutela provisória for decidida pelo relator, deverá o réu interpor o recurso de agravo interno para evitar a estabilização (art. 1.021, CPC). Outrossim, se decidida por acórdão, não estará sujeita a recurso extraordinário, por força do enunciado n. ${ }^{\circ} 735$ do Colendo Supremo Tribunal Federal, mas sendo permitido o manejo de apelo especial, desde que o recurso verse sobre o preenchimento dos pressupostos da concessão da medida, a teor do decidido pela $1^{\text {a }}$ Turma do Superior Tribunal de Justiça, no REsp n. ${ }^{\circ} 816.050 / R N$, de relatoria do Exm $^{\circ}$ Sr. Ministro Teori Albino Zavascki, julgado em 28 de março de 2006, publicado no DJ de 10 de abril de 2006, p. 163.

Ressalte-se, que essa temática demonstrou a necessidade de reflexão sobre a possibilidade de inércia parcial do réu, isto é, uma vez concedida a decisão antecipatória com mais de um capítulo, o réu somente impugnar em sede de recurso, contestação ou outra via de questionamento, um dos capítulos decisórios.

Nesse aspecto, acredita-se não haver óbice à estabilização na hipótese em que há recurso parcial, de modo que somente os capítulos decisórios não impugnados serão alcançados por esse fenômeno jurídico.

Por tudo isso, percebe-se que os pressupostos para a estabilização da tutela provisória satisfativa requerida em caráter antecedente são: (i) o requerimento formulado pelo autor no sentido de valer-se do benefício da tutela antecipada antecedente; (ii) a concessão integral ou parcial da tutela antecipada requerida em caráter antecedente; (ii) ausência de impugnação do réu; e (iv) não aditamento da petição inicial.

Com efeito, estabilizada a tutela a tutela antecipada antecedente extingue-se o processo sem resolução do mérito (artigo 304, §1 ${ }^{\circ}$, do Código de 2015), com a consequente condenação do réu ao pagamento das verbas de sucumbência, havendo a possibilidade de reduzir os honorários advocatícios pela metade do mínimo geral $(5 \%)$.

Ademais, de acordo com o art. 304, $\$ 5^{\circ}$, do CPC, os efeitos da tutela estabilizada ficam conservados enquanto não houver nova ação autônoma para revisá-los, reformá-los ou invalidá-los, que deverá ser ajuizada no prazo 
decadencial de dois anos, contados da ciência da decisão que extinguiu o processo originário.

Desse ponto surge outra relevante divergência concernente ao cabimento da ação rescisória e a formação da coisa julgada da decisão após o decurso do prazo de 02 (dois) anos da extinção do processo.

Destarte, o direito a essa nova ação extingue-se após dois anos da ciência da decisão que extinguiu o processo. Nesse passo, uma vez transcorrido esse prazo entende-se que não há incidência da coisa julgada, eis que o instituto da estabilização da tutela antecedente é próprio dos procedimentos de cognição exauriente.

Por conseguinte, é de se reconhecer o não cabimento da ação rescisória contra a decisão sumária estabilizada, sem prejuízo da propositura de uma ação destinada a debater o mérito dentro do prazo decadencial ou prescricional do direito material, ainda que expirado o prazo bienal do art. $304, \S 5^{\circ}$, do CPC, em especial porque o legislador não restringiu a possibilidade de discussão do mérito, somente estabelecendo que a decisão que concedeu a tutela poderá ser revisada, reformada ou invalidada por uma nova ação, referindo-se, apenas, à decisão concessiva da tutela e não ao direito material, ou seja, à discussão da tutela estabilizada.

Por fim, a despeito da extensão dos efeitos da estabilização, demonstrou-se que pela literalidade dos artigos 303 e 304, ambos do CPC/15, a estabilização somente poderá ocorrer nos casos em que o autor requerer a tutela antecipada (satisfativa) em caráter antecedente, sendo inaplicável essa técnica à tutela de evidência e a tutela de urgência cautelar requerida em caráter antecedente.

Nesse aspecto, esse estudo reconhece a impossibilidade de estabilização em sede de tutela cautelar, notadamente porque esse instituto possui técnica conservativa, presumindo, assim, a existência de uma providência protetiva e temporária. Destarte, a tutela deve ser mantida no tempo na medida em que houver necessidade de proteção para que, posteriormente, a parte possa ver sua pretensão satisfeita.

Logo, não há como se conceber sua estabilização, o que se compatibiliza com o entendimento firmado no Enunciado n. ${ }^{\text {o }} 420$ do Fórum Permanente de Processualistas Civis, segundo o qual "não cabe estabilização de tutela cautelar". 
Por outro lado, acredita-se que inexistem obstáculos ao reconhecimento da estabilização na tutela da evidência, de modo que em sendo concedida e contra ela não se opuser o réu, poderá ser estabilizada evitando-se assim a espera do provimento definitivo, o que, de certo, atenderia aos fins do Código de Processo Civil de 2015: a entrega de uma prestação jurisdicional célere, justa e eficiente.

Em suma, o estudo desenvolvido por esse trabalho reconhece que as alterações trazidas pelo CPC/2015 podem proporcionar maior eficiência na entrega jurisdicional. Não obstante, depreende-se que a doutrina e a jurisprudência possuem papel fundamental para seu alcance, em vista da não pacificação de muitos assuntos aqui debatidos.

Assim é que somente a prática e o tempo poderão assegurar aos aplicadores do direito a busca da máxima eficácia desses institutos. 


\section{7 \\ Referências Bibliográficas}

ALMEIDA, Flávio Renato Correia de; TALAMINI, Eduardo; WAMBIER, Luiz Rodrigues. Curso avançado de processo civil. 10. ed. São Paulo: RT, 2008, v. 1.

ANDRADE, Érico; NUNES, Diele. Os contornos da estabilização da tutela provisória de urgência antecipatória no novo CPC e o "mistério" da ausência de formação da coisa julgada. In.: FREIRE, Alexandre; BARROS, Lucas Buril de Macedo; PEIXOTO, Ravi. Coletânea Novo CPC: Doutrina Selecionada. Salvador: Juspodivm, 2015.

AURELLI, Arlete Inês. Liminares nos procedimentos especiais e o novo CPC. 2016. In: SCARPELLI, Natália Calçado. Estabilização da tutela provisória de urgência antecipada requerida em caráter antecedente. 2016. 186 f. Dissertação (Mestrado em Direito Processual Civil) - Pontifícia Universidade Católica de São Paulo (PUC-SP), São Paulo, 2016.

BAUERMANN, Desirê. Estabilização da tutela antecipada. Revista Eletrônica de Direito Processual - REDP, Rio de Janeiro, v. 4, p. 32-48. Disponível em: <http://www.e-publicacoes.uerj.br/index.php/redp/article/view/21567/15569>. Acesso em: 18 abr. 2018.

BEDAQUE, José Roberto dos Santos. Tutela cautelar e tutela antecipada: tutelas sumárias e de urgência. 3. ed. São Paulo: Malheiros, 2003.

BRASIL. Decreto-lei $\mathrm{n}^{\circ} 1.608$, de 18 de setembro de 1939. Código de processo civil. Disponível em: <http://www.planalto.gov.br/ccivil_03/decretolei/19371946/Del1608.htm>. Acesso em: 10 abr. 2018.

Lei $\mathrm{n}^{\circ}$ 5.869, de 11 de janeiro de 1973. Código de processo civil. Disponível em: <http://www.planalto.gov.br/ccivil_03/LEIS/L5869.htm>. Acesso em: 10 abr. 2018.

Lei $\mathrm{n}^{\circ} 10.444$, de 07 de maio de 2002. Altera a Lei $\mathbf{n}^{0}$ 5.869, de 11 de janeiro de 1973 (Código de Processo Civil). Disponível em: <http://www.planalto.gov.br/Ccivil_03/leis/2002/L10444.htm>. Acesso em 10 abr. 2018.

Superior Tribunal de Justiça. REsp n. ${ }^{\circ}$ 816.050/RN, Rel. Min. Teori Albino Zavascki, $1^{\text {a }}$ Turma, DJe 10/04/2006. Disponível em: <http://www.stj.jus.br/SCON>. Acesso em: 16 mar. 2018.

$\begin{array}{ccccc}\text { código } & \text { Senado Federal. Projeto de Lei } & 166, \text { de 2010. Dispõe sobre a reforma do } \\ \text { de } & \text { processo } & \text { civil. } & \text { Disponível } & \text { em: }\end{array}$ <https://www25.senado.leg.br/web/atividade/materias/-/materia/97249>. Acesso em: 22 abr. 2018. 
Lei 13.105, de 16 de março de 2015. Código de processo civil. Disponível em: <http://www.planalto.gov.br/ccivil_03/_ato2015-2018/2015/lei/113105.htm>. Acesso em: 02 abr. 2018.

BUENO, Cassio Scarpinella. Curso sistematizado de direito processual civil: tutela antecipada, tutela cautelar e procedimentos cautelares específicos. 6. ed. São Paulo: Saraiva, 2014.

Manual de direito processual civil. 2. ed. São Paulo: Saraiva, 2016.

BUZAID, Alfredo. A influência de Liebman no direito processual civil brasileiro. Revista de Processo. vol. 27. p. 12-26. São Paulo: RT, Jul - Set/1982.

CÂMARA, Alexandre Freitas. O novo processo civil brasileiro. São Paulo: Atlas, 2015.

Alexandre Freitas. O novo processo civil brasileiro. 2. ed. São Paulo: Atlas, $2016 . \quad$ Disponível em: <https://www.academia.edu/32073955/C\%C3\%82MARA_Alexandre_Freitas._ O_Novo_Processo_Civil_Brasileiro._2._ed>. Acesso em: 10 abr. 2018.

CAMBI, Eduardo; NEVES, Aline Regina das. Acesso à justiça, tutela antecipada e técnicas processuais. In: DIDIER JR., Fredie; FREIRE, Alexandre; MACÊDO, Lucas Buril de; PEIXOTO, Ravi (Orgs.). Procedimentos especiais, tutela provisória e direito transitório. Coleção Novo CPC. Doutrina Selecionada. 2. ed. Salvador: Juspodivm, 2016, v. 4.

CARNEIRO, Athos Gusmão. Da antecipação de tutela. 5. ed. Rio de Janeiro: Forense, 2004.

CAVALCANTI NETO, Antônio de Moura. Estabilização da tutela antecipada antecedente: tentativa de sistematização. 2015. p. 14-15. Disponível em:< http://www.academia.edu/12283645/Estabiliza\%C3\%A7\%C3\%A3o_da_tutela_a ntecipada_antecedente_tentativa_de_sistematiza\%C3\%A7\%C3\%A3o $>$. Acesso em: 25 abr. 2018.

Estabilização da tutela antecipada antecedente: tentativa de sistematização. In: COSTA, Eduardo José da Fonseca; DIDIER JR., Fredie; GOUVEIA FILHO, Roberto P. Campos; PEREIRA, Mateus Costa (Orgs.). Tutela provisória. Coleção Grandes Temas do Novo CPC. Salvador: Juspodivm, 2016, v. 6. p. 216.

CONCEIÇÃO, Maria Lúcia Lins; MELLO, Rogerio Licastro Torres de; RIBEIRO, Leonardo Ferres da Silva; WAMBIER, Teresa Arruda Alvim. Primeiros comentários ao novo código de processo civil. São Paulo: RT, 2015.

COSTA, Adriano Soares da. Morte processual da ação cautelar? In: COSTA, Eduardo José da Fonseca; DIDIER JR., Fredie; GOUVEIA FILHO, Roberto P. Campos; PEREIRA, Mateus Costa (Orgs.). Tutela provisória. Coleção Grandes Temas do Novo CPC. Salvador: Juspodivm, 2016. 
; GOUVEIA FILHO, Roberto P. Campos; PEIXOTO, Ravi. Estabilização, imutabilidade das eficácias antecipadas e eficácia de coisa julgada: um diálogo pontiano com o CPC/2015. In: DIDIER JR., Fredie; FREIRE, Alexandre; MACÊDO, Lucas Buril de; PEIXOTO, Ravi (Orgs.). Procedimentos especiais, tutela provisória e direito transitório. Coleção Novo CPC. Doutrina Selecionada. 2. ed. Salvador: Juspodivm, 2016, v. 4.

CUNHA, Guilherme Cardoso Antunes da. Tutelas de urgência satisfativas autônomas. Revista de Processo. v. 227, a. 39. p. 141. São Paulo: RT, jan. 2014.

CUNHA, Leonardo Carneiro da. A Fazenda Pública em juízo. 13. ed. São Paulo: Forense, 2016.

DIDIER JR., Fredie; BRAGA, Paula Sarno; OLIVEIRA, Rafael Alexandria de. Curso de direito processual civil. 11. ed. Salvador: Juspodivm, 2016, v. 2.

ENCONTRO DO FÓRUM PERMANENTE DE PROCESSUALISTAS CIVIS. 7., 2016, São Paulo. Enunciados do Fórum Permanente de Processualistas Civis. Disponível em: <http: //www.cpcnovo.com.br/wp-content/uploads/2016/06/FPPCCarta-de-Sa\%CC\%83o-Paulo.pdf >. Acesso em: 16 abr. 2018.

FERREIRA, Gabriela Macedo. Estabilização da tutela de urgência antecipada no Novo Código de Processo Civil. jan. 2017. Disponível em: < http: //www. cecgp. com. br/ noticias/ 1537- estabilizacao- da- tutela- de- urgencia- antecipadano-novo-codigo-de-processo-civil-artigo-da-juiza-federal-gabriela-macedoferreira>. Acesso em: 26 mar. 2018.

FUX, Luiz. Comissão de Juristas Responsável pela Elaboração de Anteprojeto de Código de Processo Civil. Exposição de motivos do anteprojeto de código de processo civil de 2015. Disponível em: <http://www.senado.gov.br/senado/novocpc/pdf/Anteprojeto.pdf $>$. Acesso em: 11 mar. 2018.

GODINHO, Robson Renault. Comentários aos artigos 294 a 311. In CABRAL, Antonio do Passo; CRAMER, Ronaldo (Coord). Comentários ao novo código de processo civil. 2. ed. Rio de Janeiro: Forense, 2016.

GRECO, Leonardo. Jurisdição voluntária moderna. São Paulo: Dialética. 2003.

A tutela de urgência e a tutela de evidência no código de processo civil de 2014/2015. Revista Eletrônica de Direito Processual. v. XIV, ano 8. p. 306. jul.dez. 2014.

A tutela da urgência e a tutela da evidência no código de processo civil de 2015. In: RIBEIRO, Darci Guimarães; JOBIM, Marco Félix. (Org.). Desvendando o novo CPC. 2. ed. Porto Alegre: Livraria do Advogado, 2016. 
A tutela da urgência e a tutela da evidência no código de processo civil de 2015. In: DIDIER JR., Fredie; FREIRE, Alexandre; MACÊDO, Lucas Buril de; PEIXOTO, Ravi (Orgs.). Procedimentos especiais, tutela provisória e direito transitório. Coleção Novo CPC. Doutrina Selecionada. 2. ed. Salvador: Juspodivm, 2016, v. 4.

KOEHLER, Frederico Augusto Leopoldino; MIRANDA, Gabriela Expósito Tenório. Estabilização da tutela antecipada antecedente: tentativa de sistematização. In: DIDIER JR., Fredie. Tutela provisória. Salvador: Juspodivm, 2016.

LOPES, João Batista. Tutela antecipada. 4. ed. São Paulo: RT, 2009.

MACEDO, Elaine Harzheim. Prestação jurisdicional em sede de tutela antecedente. Procedimento, estabilização da decisão e decurso do prazo de 2 (dois) anos: um novo caso de perempção? Revista de Processo. vol. 250, p. 189-215. São Paulo: RT, Dez/2015.

MARINONI, Luiz Guilherme. Tutela cautelar e tutela antecipatória. São Paulo: RT, 1992.

Da tutela cautelar à tutela antecipatória. 2012. Disponível em: <http://www.marinoni.adv.br/home/artigos/>. Acesso em: 08 abr. 2018

; ARENHART, Sérgio Cruz; MITIDIERO, Daniel. Novo curso de processo civil: tutela dos direitos mediante procedimento comum. São Paulo: RT, 2015, v. 2.

MARINONI, Luiz Guilherme; ARENHART, Sérgio Cruz; MITIDIERO, Daniel. Novo código de processo civil comentado. São Paulo: RT, 2015.

Tutela de urgência e tutela de evidência. 1. ed. São Paulo: RT, 2017.

MEDINA, José Miguel Garcia de. A tutela antecipatória e o perigo de irreversibilidade do provimento. Revista de Processo. vol. 86, p. 24-34. São Paulo: RT, Abr - Jun/1997.

Novo código de processo civil comentado: com remissões e notas comparativas ao CPC/73. 3. ed. São Paulo: RT, 2015.

MIOTTO, Carolina Cristina. A evolução do direito processual civil brasileiro: de 1939 a análise dos objetivos visados pelo Projeto de Lei n. 8.046 de 2010. Disponível em: $<$ http://periodicos.unifebe.edu.br/index.php/revistaeletronicadaunifebe/article/vie wFile/135/66>. Acesso em: 16 abr. 2018.

MITIDIERO, Daniel Francisco. Tendências em matéria de tutela sumária: da tutela cautelar à técnica antecipatória. Revista de Processo. vol. 197, p. 27-65. São Paulo: RT, Jul/2011. 
Automização e estabilização da antecipação da tutela no novo código de processo civil. Revista Magister de Direito Civil e Processo Civil, Porto Alegre, n. 63, nov/dez. 2014.

NERY JR., Nelson; NERY, Rosa Maria de Andrade. Código de processo civil comentado e legislação extravagante. 11. ed. São Paulo: RT, 2010.

NEVES, Daniel Amorim Assumpção. Novo código de processo civil: Lei 13.105/2015. São Paulo: Método, 2016.

NUNES, Elpídio Donizetti. Curso didático de direito processual civil. 2. ed. Belo Horizonte: Del Rey, 1999.

OLIVEIRA, Antônio Francisco de. Alterações do CPC: aspectos processuais trabalhistas e civis. São Paulo: RT, 1997.

OLIVEIRA NETO, Olavo de; MEDEIROS NETO, Elias Marques de; OLIVEIRA, Patrícia Elias Cozzolino de. Curso de direito processual civil. 1. ed. São Paulo: Verbatim, 2015, v. 1.

OLIVEIRA, Weber Luiz de. Estabilização da tutela antecipada e teoria do fato consumado. Estabilização da estabilização? Revista de Processo. v. 242, a. 40. São Paulo: RT, abr. 2015.

PACHECO, José da Silva. Evolução do processo civil brasileiro: desde as origens até o advento do novo milênio. 2. ed. Rio de Janeiro: Renovar, 1999.

PASSOS, J. J. Calmon de. Comentários ao código de processo civil. 9. ed. Rio de Janeiro: Forense, 2004, v. 3.

PEIXOTO, Ravi. Por uma análise dos remédios jurídicos processuais aptos a impedir a estabilização da tutela antecipada antecedente de urgência. In: COSTA, Eduardo José da Fonseca; DIDIER JR., Fredie; GOUVEIA FILHO, Roberto P. Campos; PEREIRA, Mateus Costa (Orgs.). Tutela provisória. Coleção Grandes Temas do Novo CPC. Salvador: Juspodivm, 2016, v. 6.

REDONDO, Bruno Garcia. Tutela de urgência ("efeito suspensivo" e "tutela antecipada") em grau recursal e deveres-poderes do relator. Revista de Processo. vol. 209, p. 55-71. São Paulo: RT, Jul/2012.

Estabilização, modificação e negociação da tutela de urgência antecipada antecedente: principais controvérsias. Revista de Processo. v. 244, a. 40. p. 167194. São Paulo: RT, jun. 2015.

RIBEIRO, Leonardo Ferres da Silva. Tutela provisória: tutela de urgência e tutela da evidência - do CPC/1973 ao CPC/2015. São Paulo: RT, 2015.

RODRIGUES, Marcelo Abelha. Manual de direito processual civil. 5. ed. São Paulo: RT, 2010. 
RUANOBA, Sebastian Watenberg. Fungibilidade das tutelas de urgência (antecipatória e cautelar) no processo civil brasileiro. Revista de Processo. vol. 148. p. 321-352. São Paulo: RT, Jun/2007.

SAMPAIO JR., José Herval. Tutela cautelar no novo CPC. In: COSTA, Eduardo José da Fonseca; DIDIER JR., Fredie; GOUVEIA FILHO, Roberto P. Campos; PEREIRA, Mateus Costa (Orgs.). Tutela provisória. Coleção Grandes Temas do Novo CPC. Salvador: Juspodivm, 2016, v. 6.

SANTOS, Ernane Fidélis dos. Manual de direito processual civil. 4. ed. São Paulo: Saraiva, 1996, v. 3.

Manual de direito processual civil. 4. ed. São Paulo: Saraiva, 1993. v. 1.

SCARPARO, Eduardo. A supressão do processo cautelar como tertium genus no Código de Processo Civil de 2015. In: BOECKEL, Fabrício Dani de; ROSA, Karin Regina Rick; SCARPARO, Eduardo (Orgs.). Estudos sobre o novo código de processo civil. Porto Alegre: Livraria do Advogado, 2015.

SCARPELLI, Natália Calçado. Estabilização da tutela provisória de urgência antecipada requerida em caráter antecedente. 2016. 186 f. Dissertação (Mestrado em Direito Processual Civil) - Pontifícia Universidade Católica de São Paulo (PUC-SP), São Paulo, 2016.

SICA, Heitor Vitor Mendonça. Doze problemas e onze soluções quanto à chamada "estabilização da tutela antecipada". Revista do Ministério Público do Rio de Janeiro. n. ${ }^{\circ}$ 55, jan/mar 2015, p. 87. Disponível em: < http://publicacao.mprj.mp.br/rmprj/rmprj_55/files/assets/basic-

html/page90.html>. Acesso em: 16 abr. 2018.

SILVA, Ovídio A. Baptista da. Do processo cautelar. 3. ed. Rio de Janeiro: Forense, 2006.

Curso de processo civil. 5. ed. São Paulo: RT, 2001, v. 1.

SOUZA, Artur César de. Análise da Tutela Antecipada prevista no relatório final da Câmara dos Deputados em relação ao novo CPC (LGL\197315); da tutela de evidência e da tutela satisfativa última parte. Revista de Processo. vol. 235, ano 39. p. 151-186. São Paulo: RT, set. 2014.

TALAMINI, Eduardo. Tutela de urgência no projeto de novo código de processo civil: a estabilização da medida urgente e a "monitorização" do processo civil brasileiro. Revista de Processo. n. 209, v. 37, jul/2012.

; WAMBIER, Luiz Rodrigues. Curso avançado de processo civil: cognição jurisdicional (processo comum de conhecimento e tutela provisória). 16. ed. São Paulo: RT, 2016. v. 2.

THEODORO JR., Humberto. Curso de direito processual civil. 20. ed. Rio de Janeiro: Forense, 1997, v. 2. 
Tutela antecipada e tutela cautelar. Revista de Processo. vol. 742, p. 4056. São Paulo: RT, Ago/1997.

Curso de direito processual civil: Teoria geral do processo civil, processo de conhecimento e procedimento comum. 57. ed. Rio de Janeiro: Forense, 2016, v. 1.

VIANA, Juvêncio Vasconcelos. História do processo: uma análise do código de processo civil de 1939 sob o prisma terminológico. Disponível em: <http: //www.buscalegis.ufsc.br/revistas/files/anexos/9201-9200-1-PB.pdf.>. Acesso em: 16 abr. 2018.

WAMBIER, Teresa Arruda Alvim; CONCEIÇÃO, Maria Lúcia Lins; RIBEIRO, Leonardo Ferres da Silva; MELLO, Rogério Licastro Torres de. Primeiros comentários ao novo código de processo civil: artigo por artigo. São Paulo: RT, 2015 .

WATANABE, Kazuo. Da cognição no processo civil. 4. ed. São Paulo: Saraiva, 2012.

ZAVASCKI, Teori Albino. Antecipação de tutela. 6. ed. São Paulo: Saraiva, 2008. 